\title{
Radium isotopes and radon-222 as tracers of sediment-water interaction in Arctic coastal and lacustrine environments
}

by

\author{
Jessica Stephanie Dabrowski
}

B.S. Chemistry and Environmental Studies, Tufts University, 2017

Submitted to the Department of Earth, Atmospheric, and Planetary Sciences in partial fulfillment of the requirements for the degree of

Master of Science

at the

\section{MASSACHUSETTS INSTITUTE OF TECHNOLOGY \\ and the \\ WOODS HOLE OCEANOGRAPHIC INSTITUTION}

September 2020

(C) 2020 Jessica Stephanie Dabrowski. All rights reserved.

The author hereby grants to MIT and WHOI permission to reproduce and to distribute publicly paper and electronic copies of this thesis document in whole or in part in any medium now known or hereafter created.

Signature of Author

Joint Program in Oceanography/Applied Ocean Science and Engineering Massachusetts Institute of Technology and Woods Hole Oceanographic Institution August 3, 2020

Certified by

Dr. Matthew A. Charette Thesis Supervisor

Accepted by

Woods Hole Oceanographic Institution

Dr. Collen M. Hansel Chair, Joint Committee for Chemical Oceanography Woods Hole Oceanographic Institution 


\title{
Radium isotopes and radon-222 as tracers of sediment-water interaction in Arctic coastal and lacustrine environments
}

By

\author{
Jessica Stephanie Dabrowski
}

Submitted to the Department of Earth, Atmospheric, and Planetary Sciences at the Massachusetts Institute of Technology and the Woods Hole Oceanographic Institution on August 3, 2020, in partial fulfillment of the requirements for the degree of Masters of Science in Chemical Oceanography.

\begin{abstract}
Arctic marine and lacustrine systems are experiencing rapid warming due to climate change. These changes are especially important at the interface between sediments and surface waters because they are hotspots for biogeochemical transformations such as redox reactions, nutrient consumption and regeneration, organic matter leaching and degradation, and mineral weathering. Radium isotopes $\left({ }^{223} \mathrm{Ra},{ }^{224} \mathrm{Ra},{ }^{226} \mathrm{Ra},{ }^{228} \mathrm{Ra}\right)$ and radon-222, naturally occurring radioactive isotopes produced in sediments, are well-suited as tracers of nutrients, trace metals, and organic matter cycling processes at the sediment-water interface. In this thesis, I have applied radon-222 and the quartet of radium isotopes to study fundamental processes in subarctic lakes and on the Arctic continental shelf.
\end{abstract}

First, radon-222 is used to quantify groundwater discharge into a shallow, tundra lake on the Yukon-Kuskokwim Delta in Alaska in summer of 2017. Radon-derived groundwater fluxes were then paired with methane $\left(\mathrm{CH}_{4}\right)$ measurements to determine delivery rates of methane into the lake via groundwater. Groundwater $\mathrm{CH}_{4}$ fluxes significantly exceeded diffusive air-water fluxes from the lake to the atmosphere, suggesting that groundwater is an important source of $\mathrm{CH}_{4}$ to Arctic lakes and may drive observed $\mathrm{CH}_{4}$ emissions. Higher $\mathrm{CH}_{4}$ emissions were observed compared to those reported previously in high latitude lakes, like due to higher $\mathrm{CH}_{4}$ concentrations in groundwater. These findings indicate that deltaic lakes across warmer permafrost regions may act as important hotspots for methane release across Arctic landscapes. Then, the quartet of radium isotopes is used to study the impacts of storms and sea ice formation as drivers of sediment-water interaction on the Alaskan Beaufort shelf. The timeseries presented in this study is among the first to document the combined physical and chemical signals of winter water formation in the Beaufort Sea, made possible by repeat occupations of the central Beaufort shelf. Radium measurements are combined with inorganic nitrogen and hydrographic measurements to elucidate the episodic behavior of winter water formation and its ability to drive exchange with bottom sediments during freeze-up.

Thesis Supervisor: Dr. Matthew A, Charette

Title: Senior Scientist, Woods Hole Oceanographic Institution 


\section{Acknowledgements}

These past three years have been some of the most enlightening, transformative, and exciting years of my life. I'm grateful for my time in the Joint Program and all that it has taught me both personally and professionally.

I want to thank my advisor and mentor, Matt Charette, for the seemingly endless opportunities he gave me, that sent me around the entire Northern Hemisphere, from western Alaska to eastern Siberia for field work, and everywhere in between for schooling and conference opportunities. I have learned a lot from him about how to be an excellent scientist, confident leader, and understanding mentor to others. I thank him for being so understanding during the crazy last few months when COVID-19 interrupted our lives.

Paul Henderson has been so supportive both as technical support and as a great friend in the lab. Thank you for all of your support in the lab and in the field, in helping teach me about all of the instruments, in helping me pack for fieldwork, and in helping carry cubitainers back to the car before the Kodiak bears tore up my samples. Thank you for answering all of my questions, no matter what you busy with. I also want to thank my other lab members during my time at WHOI, especially Lauren Kipp, Joseph Tamborski, and Emilie Le Roy, for their guidance and companionship.

I'm thankful to the support of my other mentors. Bob Pickart gave me an amazing opportunity to join a cruise to the Arctic, mentored me through the craziness that is a P.O. cruise for a chemist, and has helped me so much in developing my ideas and editing my work. Thank you to Miguel Goñi for your guidance and friendship during long nights on the cruise and for all the talks we had about careers and lifelong dreams. Thank you to Paul Mann for your guidance during my first field expedition to the remote corners of Alaska, the opportunity to sample in the reaches of Eastern Siberia, and all our conversations when we ended up on the same continent. I'm thankful to David McGee and Ann Dunlea from my committee for their swift action during my short thesis timeline and their guidance.

I'm thankful for the women scientists and mentors in my life, especially Meg Tivey, Sue Natali, Liz Sikes, and Claudia Benitez-Nelson, who modeled independence, leadership, unwavering confidence, and humility and laughter through it all.

I owe so many thanks to the members of the Academic Programs Office (Meg Tivey, Delia Oppo, Julia Westwater, Lea Fraser, Christine Charette, Valerie Caron, and Martha Bridgers) for keeping the Joint Program running and for addressing any need from a caring ear to reimbursements, to figuring out how registration works. The MC\&G staff (Sheila Clifford, Donna Mortimer, Mary Murphy, and Mary Zawoysky) also answered so many of my questions, created a welcoming and well-functioning department, and made it a little bit brighter with all their dogs. Thank you to the support of the department chair, Bernhard Peucker-Ehrenbrink, and education coordinator, Jeff Seewald. 
Thank you to the coaches and mentors I have had outside the Joint Program, Rachel and Jonnie, who have helped me discover myself, have been and continue to be great friends, and who have taught me that my dreams are attainable.

Thank you to all the friends I have made inside and outside of the Joint Program during this time, especially Alia Hidayat, Becca Chmiel, Emman Codillo, Ellen Lalk, Marissa Kellogg, to the rest of the Sunfish and JP students: thank you for all the cry-able and laughable moments.

Thank you to my family, especially my rock-star of a mom, who has held our family together through the roughest of times, who will do anything for me and my siblings, and who taught me independence, resilience, and bravery.

Thank you most of all to my partner, Alex, for all the time we spent together, for the hours you listened to me talk about everything from science to mental health to entrepreneurship, for the support you have given me and continue to relentlessly provide, for holding my hand when things got (really, really) hard, for making me laugh and smile, and for your support through all the personal and career roller coasters that life has taken me through.

\section{Financial Support}

Financial support for Chapter 2 was funded by National Science Foundation awards OCE1458305 to M.A.C., 1561437 to S.M.N, J.D.S., and R.M.H and 1624927 to S.M.N., P.J.M. and R.M.H. The work completed for Chapter 3 was funded by the Montrym Fund at the Massachusetts Institute of Technology, the Academic Programs Office at Woods Hole Oceanographic Institution, and the NSF Arctic GEOTRACES (OCE-1458305), Pacific GEOTRACES (OCE-1736277), and Arctic Observing Network programs (OPP-1733564). 


\section{Table of Contents}

Abstract _ 3

Acknowledgements _ 5

List of Figures _ 9

List of Tables _ 10

Chapter 1: Introduction __ 11

1.1 Importance of sediment-water interaction in the Arctic 12

1.2 Radioactive isotopes as tracers of sediment-water interaction__ 12

1.2.1 Subarctic lakes _ 13

1.2.2 Arctic continental shelves _ 13

References _ 15

Chapter 2: Using radon to quantify groundwater discharge and methane fluxes to a shallow, tundra lake on the Yukon-Kuskokwim Delta, Alaska __ 21

Abstract _ 21

2.1 Introduction 22

2.2 Materials and Methods _ 23

2.2.1 Study site _ 23

2.2.2 Sample collection _ 24

2.2.3 Sample analysis _ 25

2.2.3.1 Radioisotopes _ 25

2.2.3.2 Methane 26

2.2.3.3 $\delta^{18} \mathrm{O}$ and $\delta^{2} \mathrm{H}$

2.2.3.4 Soil characterization 27

2.2.4 Statistical analyses __ 28

2.3 Results 28

2.3.1 Radioisotopes — 28

2.3.2 Methane 29

2.3.3 $\delta^{18} \mathrm{O}$ and $\boldsymbol{\delta}^{2} \mathrm{H}$

2.4 Discussion__ 30

2.4.1 Radon sources and sinks _ 30

2.4.1.1 Sinks of ${ }^{222} \mathrm{Rn}$ : gas exchange, decay, streams, and recharge ___ 31

2.4.1.2 Sources of ${ }^{222} \mathrm{Rn}$ : dissolved ${ }^{226} \mathrm{Ra}$, sediments, ground water__ 32 
2.4.2 Methane in Landing Lake __ 35

Acknowledgements _ 37

References _ 38

Chapter 3: Autumn storms and winter water formation as drivers of sediment-water interaction on the Beaufort Sea Shelf

Abstract

3.1 Introduction__ 58

3.2 Study Area _ 59

3.3 Methods 60

3.3.1 Sample collection and analysis _ 60

3.3.2 Meteorological and sea ice data___ 62

3.4 Results _ 62

3.4.1 Wind events and sea ice concentration __ 63

3.4.2 Hydrographic observations __ 63

3.4.3 Radium isotopes \& nutrients ___ 64

3.4.4 Sediments__ 66

3.4.5 Radium ages __ 66

3.5 Discussion__ 67

3.5.1 Tracers of sediment-water interaction __ 67

3.5.2 Post-Period 1 (Nov 2-3, 2018): Inner shelf WW formation __ 67

3.5.3 Period 2 (Nov 3-7, 2018): Storm 2 and central shelf WW formation __ 68

3.5.4 Period 3 (Nov 10-14): Storm 3 and WW development __ 69

3.6 Conclusion 70

Acknowledgements _ 71

References _ 72

Chapter 4: Summary and future research directions ___ 103

References _ 107 


\section{List of Figures}

\section{Chapter 2}

Figure 1 "Landing Lake" sampling locations and the study site location

Figure 2 Concentrations of (a) dissolved ${ }^{222} \mathrm{Rn}$ and (b) dissolved methane in Landing Lake _ 52

Figure 3 Stable carbon isotopes of dissolved $\mathrm{CH}_{4}$ as a function of $\mathrm{CH}_{4}$ concentration in groundwater 53

Figure 4 The stable isotope values for $\delta^{2} \mathrm{H}$ and $\delta^{18} \mathrm{O}$ in water samples___ 54

Figure 5 A conceptual model showing the sources and sinks of 222Rn in Landing Lake __ 55

Figure 6 The fluxes of ${ }^{222} \mathrm{Rn}$ for each source and sink in the mass balance model for Landing

Lake 56

\section{Chapter 3}

Figure 1 Schematic circulation of the Chukchi and western Beaufort seas 82

Figure 2 Map of study area and locations of sampling stations 83

Figure 3 Alongcoast wind and air-temperature

Figure 4 Composite maps of sea level pressure 84

Figure 5 Composite vector maps of the $10-\mathrm{m}$ wind 85

Figure 6 Snapshots showing regions where polynyas were present 86

Figure 7 Vertical sections of temperatur, potential density, geostrophic velocity, and beam transmission for a subset of the cruise transects 88

Figure 8 Radium isotopes on the Beaufort shelf and slope 89

Figure 9 Radium samples from this study compared to previous studies near the Alaskan \& Canadian Beaufort Shelves

Figure 10 (a) ${ }^{228} \mathrm{Ra}$ and (b) ${ }^{223} \mathrm{Ra}$ ex plotted with respect to ammonium concentrations 90

Figure 11 Ammonium concentrations in the central Beaufort Sea 91

Figure 12 Radium isotopes in Beaufort Sea shelf sediments 92

Figure 13 Radium ages of bottom waters (time since sediment-water interaction) in the central Beaufort Sea 94

Figure 14 Wind speeds, ice concentrations and radium-228 activities 95

Figure S1 Hydrographic data in the Eastern Beaufort Sea at $139^{\circ} \mathrm{W}$ on Nov 5, $2018 \_96$ Figure S2 Hydrographic data in the Eastern Beaufort Sea at $144^{\circ} \mathrm{W}$ on Nov 4-5, $2018 \_$__ 97 Figure S3 Depth-averaged velocity vectors from the shipboard acoustic Doppler current profiler

Figure S4 Radium isotopes in the eastern Beaufort Sea during Period 2, on Nov 4-5 ${ }^{\text {th }}, 2018$ _ 99

Figure S5 Ammonium concentrations in the eastern Beaufort Sea during period 2 100

Figure S6 Sediment efficiencies for the 220-channel of the Radium Delayed Coincidence Counter using Th-232-spiked sediment 101 


\section{List of Tables}

\section{Chapter 2}

Table $1{ }^{222} \mathrm{Rn}$ activities and dissolved $\mathrm{CH}_{4}$ concentrations measured at Landing Lake 44

Table $2{ }^{222} \mathrm{Rn}$ activities and dissolved $\mathrm{CH}_{4}$ concentrations measured in groundwater and incubated soils 45

Table 3 Measured soil and sediment characteristics used in the incubation experiments 46 Table 4 Groundwater samples collected in 2017 (including those near Landing Lake and other lakes) and the associated ${ }^{222} \mathrm{Rn}$ activities and methane concentrations

Table 5 Estimates of groundwater fluxes, residence times, and methane fluxes for Landing Lake compared to other studies

Table 6 The methane concentrations, measured fluxes, and measured gas exchange coefficients for Landing Lake, July 2018

Table 7 The parameters in the mass balance and the methods for estimating the uncertainty in each parameter

\section{Chapter 3}

Table 1 Radium isotope samples from cruise HLY1803, Oct-Nov 2018. 
Chapter 1: Introduction 


\subsection{Importance of sediment-water interaction in the Arctic}

The Arctic is warming two times faster than the global average, with $8^{\circ} \mathrm{C}$ of warming expected by 2100 (Schuur et al., 2008), causing rapid loss of sea ice, increased river runoff, coastal erosion, glacial melting, and permafrost thawing (Holmes et al., 2012; IPCC, 2014). These shifts impact local ecosystems and people living in the Arctic, and have significant consequences for the global carbon cycle (Anderson \& Macdonald, 2015; Walter Anthony et al., 2018), ocean circulation (Jungclaus et al., 2005), and global trade (Borgerson, 2008). Further, many processes are still not fundamentally understood due to lack of data coverage, especially in winter, and geopolitical obstacles.

Arctic research is especially needed at the land-ocean interface, a dominant environment in this system. This basin is surrounded by land containing thawing permafrost (Schuur et al., 2015), is $1 \%$ of the global ocean volume but receives $>10 \%$ of global river discharge (McClelland et al., 2012), and is made up of 50\% continental shelves by area (Jakobsson, 2002). Sediment-water interactions (SWI) are common across the land-ocean continuum and are key areas for biogeochemical transformations such as redox reactions, supplying nutrients, organic matter leaching and degradation, and mineral weathering. Examples of SWI are groundwater discharge, resuspension, and diffusive exchange. As permafrost thaws and the hydrologic cycle intensifies, groundwater flow is expected to increase relative to surface runoff (Walvoord \& Kurylyk, 2016), and open water will drive enhanced vertical mixing on shelves and increased coastal erosion (Carmack et al., 2016; Couture et al., 2018; Rainville et al., 2011; Rutgers van der Loeff et al., 2018). We are already observing increased phytoplankton biomass in the Arctic Ocean due to increasing nutrient inputs (Lewis et al., 2020). Hence, SWI will become increasingly important with climate change.

\subsection{Radioactive isotopes as tracers of sediment-water interaction}

Radium and radon isotopes have proven to be useful tools for quantifying groundwater discharge, solute fluxes, residence times in estuaries and on shelves, sediment-water interaction, and shelf-basin exchange (Charette et al., 2008, 2016; Elsinger \& Moore, 1984; Moore, 2000a). These radionuclides are produced in soils and sediments by naturally occurring uranium and thorium, and are soluble in water, unlike their particle-bound parents (Charette, 2007), so they also trace movement of other solutes enriched in soils and sediments such as inorganic nutrients, trace metals, and organic matter. Once removed from their source, the isotopes decay at known rates according to their half-lives $\left({ }^{222} \mathrm{Rn}: \mathrm{t}_{1 / 2}=3.82 \mathrm{~d},{ }^{223} \mathrm{Ra}: \mathrm{t}_{1 / 2}=11.4 \mathrm{~d},{ }^{224} \mathrm{Ra}: \mathrm{t}_{1 / 2}=3.66 \mathrm{~d}\right.$, ${ }^{226} \mathrm{Ra}: \mathrm{t}_{1 / 2}=1600 \mathrm{y},{ }^{228} \mathrm{Ra}: \mathrm{t}_{1 / 2}=5.75 \mathrm{y}$ ), allowing us to quantify rates of processes and dates of specific events. Their radioactivity also makes these radionuclides easy to measure through alpha and gamma spectroscopy (Charette et al., 2001; Corbett et al., 1997; Key et al., 1979; Moore, 2008). For this thesis, I will apply radium and radon isotopes to study SWI in two different high latitude environments: a lake on the Alaskan tundra and the Beaufort and Chukchi continental shelves. 


\subsubsection{Subarctic lakes}

High latitude lakes are in close contact with thawing permafrost and are sources of methane to the atmosphere (Bastviken et al., 2011; Vonk et al., 2015), but their hydrology and connection to the subsurface is not well characterized (Bring et al., 2016; Lecher, 2017). Although permafrost can impede groundwater flow, increasing thaw depths in surface soils and expansions of taliks - thawed sediments beneath surface water bodies-will allow for more groundwater flow in the future (Walvoord \& Kurylyk, 2016; Woo, 2012). Groundwater discharge has been documented as a source of methane in temperate, tropical, and Arctic coastal environments (Dulaiova et al., 2010; Jeffrey et al., 2018; Lecher et al., 2016), but more work is needed to investigate the role of groundwater in northern lakes and wetlands that are large natural sources of methane to the atmosphere (Holgerson \& Raymond, 2016; Wik et al., 2016).

In Chapter 2, I investigated the importance of groundwater as a source of $\mathrm{CH}_{4}$ to a shallow tundra lake on the Yukon-Kuskowkim Delta in Alaska. Radon $\left({ }^{222} \mathrm{Rn}\right)$ was used as a natural geochemical tracer of groundwater discharge (Charette et al., 2008; Dimova et al., 2013; Dimova \& Burnett, 2011), an approach that is advantageous in regions like northern wetlands because it captures groundwater flow despite their low landscape gradients and microtopographic features that inhibit the use of traditional hydrologic methods such as seepage meters and water table elevation measurements (Morison et al., 2017b). In contrast, ${ }^{222} \mathrm{Rn}$ allows for the integration of these heterogeneities. As radon is produced naturally from decay of uranium-series radionuclides in sediments and soils, it is an ideal tracer of all groundwater sources including those present above the permafrost in the seasonally-thawed active layer, in permafrost, and in subpermafrost aquifers (Woo, 2012). Additional sources of ${ }^{222} \mathrm{Rn}$ in Arctic lakes include in-situ ${ }^{226} \mathrm{Ra}$ and diffusion from bottom sediments; sinks include decay $\left(\mathrm{t}_{1 / 2}=3.82\right.$ d), loss to the atmosphere since it is naturally a gas, and loss via outflow through streams and groundwater recharge. All sources and sinks other than groundwater discharge are measured and then groundwater discharge rates are then solved through a "flux-by-difference" approach (Charette et al., 2008). Then groundwater-derived $\mathrm{CH}_{4}$ fluxes to the lake are estimated and compared to measured air-water diffusive fluxes and stable isotopes.

\subsubsection{Arctic continental shelves}

Climate warming is causing sea ice loss over shelves allowing for increased vertical mixing and shelf-basin exchange (Carmack \& Chapman, 2003; Rainville et al., 2011; W. J. Williams \& Carmack, 2015). In the past two decades, increases in shelf-derived materials have been observed in the central Arctic (Kipp et al., 2018; Rutgers van der Loeff et al., 2018). These material inputs are in part due to SWI, which chemically transform water as it moves across the shelf, transferring nutrients, carbon, and trace metals from sediments into the water column ( $\mathrm{Z}$. W. Brown et al., 2015; Shen et al., 2016; Vieira et al., 2019). Because these inputs can influence biological productivity and greenhouse gas cycling, it is important to understand the drivers of SWI on Arctic continental shelves. On the Beaufort shelf, storms have been well-studied as drivers of upwelling (Lin et al., 2019; Pickart et al., 2009, 2011), but their impact on SWI has not 
been thoroughly investigated. Additionally, during late autumn through early spring, shelf water is transformed physically and chemically via ice formation that rejects brine and causes vertical convection, creating an Arctic water mass known as Newly Ventilated Winter Water (WW, e.g. Pacini et al., 2019). However, little is known about WW formation in late autumn and its effect on sediment-water interaction (SWI), in part due to the lack of shipboard measurements that time of year.

In Chapter 3, I investigate storms and winter water formation as drivers of SWI using a unique combination of physical and chemical observations during repeated occupations of the central Beaufort shelf in November 2018. The quartet of radium isotopes $\left({ }^{223} \mathrm{Ra}, \mathrm{t}_{1 / 2}=11.4 \mathrm{~d}\right.$; ${ }^{224} \mathrm{Ra}, \mathrm{t}_{1 / 2}=3.66 \mathrm{~d} ;{ }^{226} \mathrm{Ra}, \mathrm{t}_{1 / 2}=1600 \mathrm{y} ;{ }^{228} \mathrm{Ra}, \mathrm{t}_{1 / 2}=5.75 \mathrm{y}$ ) is used as natural tracers of SWI which can be released into the water column by diffusion, bioturbation, or sediment resuspension (Cochran et al., 1986; Macdonald \& Thomas, 1991; Moore et al., 1996). Radium-228 and ${ }^{228} \mathrm{Ra} /{ }^{226} \mathrm{Ra}$ activity ratios are well characterized as tracers of SWI on the other Arctic shelves (Kipp et al., 2018, 2020; Rutgers van der Loeff et al., 2003; Vieira et al., 2019). The short-lived radium isotopes ${ }^{224} \mathrm{Ra}$ and ${ }^{223} \mathrm{Ra}$ have a similar shelf sediment source, but their distribution is influenced by decay on timescales of days to weeks (Colbert \& Hammond, 2008; Hancock et al., 2000; Moore et al., 2006), so they can be used to observe SWI occurring due to storms and WW formation on the order of days. Ammonium produced in sediments can also be released simultaneously into coastal waters due to SWI (Bianchi et al., 1997; Z. W. Brown et al., 2015; Moore et al., 2019). Sediment-derived ammonium is similarly short-lived to ${ }^{223} \mathrm{Ra}$ and ${ }^{224} \mathrm{Ra}$, though its loss is due to biological processes in the water column (Lee et al., 2010; Tremblay et al., 2006). Together, these tracers have low backgrounds in the water column, which makes them more sensitive than ${ }^{228} \mathrm{Ra}$ or ${ }^{226} \mathrm{Ra}$ to recent SWI (Ardyna et al., 2017; Bianchi et al., 1997; Charette et al., 2008; Ku \& Luo, 2008; Moore, 2000b). The short- and long-lived chemical tracers are compared to wind and sea ice conditions on the shelf and hydrographic observations to examine the timing and chemical response of SWI due to WW formation and wind events. 


\section{References}

Anderson, L. G., \& Macdonald, R. W. (2015). Observing the Arctic Ocean carbon cycle in a changing environment. Polar Research, 34(1), 26891. https://doi.org/10.3402/polar.v34.26891

Ardyna, M., Babin, M., Devred, E., Forest, A., Gosselin, M., Raimbault, P., \& Tremblay, J. (2017). Shelf-basin gradients shape ecological phytoplankton niches and community composition in the coastal Arctic Ocean (Beaufort Sea). Limnology and Oceanography, 62(5), 2113-2132. https://doi.org/10.1002//no.10554

Bastviken, D., Tranvik, L. J., Downing, J. A., Crill, P. M., \& Enrich-Prast, A. (2011, January 7). Freshwater methane emissions offset the continental carbon sink. Science. American Association for the Advancement of Science. https://doi.org/10.1126/science.1196808

Bianchi, M., Feliatra, F., Tréguer, P., Vincendeau, M. A., \& Morvan, J. (1997). Nitrification rates, ammonium and nitrate distribution in upper layers of the water column and in sediments of the Indian sector of the Southern Ocean. Deep-Sea Research Part II: Topical Studies in Oceanography, 44(5), 1017-1032. https://doi.org/10.1016/S0967-0645(96)00109-9

Borgerson, S. G. (2008). Arctic Meltdown - The Economic and Security Implications of Global Warming. Foreign Affairs, 87. Retrieved from https://heinonline.org/HOL/Page?handle=hein.journals/fora87\&id=281\&div=\&collection= Bring, A., Fedorova, I., Dibike, Y., Hinzman, L., Mård, J., Mernild, S. H., et al. (2016). Arctic terrestrial hydrology: A synthesis of processes, regional effects, and research challenges. Journal of Geophysical Research: Biogeosciences, 121(3), 621-649.

https://doi.org/10.1002/2015JG003131

Brown, Z. W., Casciotti, K. L., Pickart, R. S., Swift, J. H., \& Arrigo, K. R. (2015). Aspects of the marine nitrogen cycle of the Chukchi Sea shelf and Canada Basin. Deep-Sea Research Part II: Topical Studies in Oceanography, 118, 73-87. https://doi.org/10.1016/j.dsr2.2015.02.009

Carmack, E. C., \& Chapman, D. C. (2003). Wind-driven shelf/basin exchange on an Arctic shelf: The joint roles of ice cover extent and shelf-break bathymetry. Geophysical Research Letters, 30(14). https://doi.org/10.1029/2003GL017526

Carmack, E. C., Yamamoto-Kawai, M., Haine, T. W. N., Bacon, S., Bluhm, B. A., Lique, C., et al. (2016). Freshwater and its role in the Arctic Marine System: Sources, disposition, storage, export, and physical and biogeochemical consequences in the Arctic and global oceans. Journal of Geophysical Research G: Biogeosciences, 121(3), 675-717.

https://doi.org/10.1002/2015JG003140

Charette, M. A. (2007). Hydrologic forcing of submarine groundwater discharge: Insight from a seasonal study of radium isotopes in a groundwater-dominated salt marsh estuary. Limnology and Oceanography, 52(1), 230-239. https://doi.org/10.4319/lo.2007.52.1.0230

Charette, M. A., Buesseler, K. O., \& Andrews, J. E. (2001). Utility of radium isotopes for evaluating the input and transport of groundwater-derived nitrogen to a Cape Cod estuary. Limnology and Oceanography, 46(2), 465-470. https://doi.org/10.4319/lo.2001.46.2.0465 
Charette, M. A., Moore, W. S., \& Burnett, W. C. (2008). Uranium-and Thorium-Series Nuclides as Tracers of Submarine Groundwater Discharge. Radioactivity in the Environment, 13, 155191.

Charette, M. A., Lam, P. J., Lohan, M. C., Kwon, E. Y., Hatje, V., Jeandel, C., et al. (2016). Coastal ocean and shelf-sea biogeochemical cycling of trace elements and isotopes: lessons learned from GEOTRACES. Transactions of the Royal Society, In press. https://doi.org/https://ora.ox.ac.uk:443/objects/uuid:ef5c9aa2-478a-407f-b183-3cc4d42366d5

Cochran, J. K., Carey, A. E., Sholkovitz, E. R., \& Surprenant, L. D. (1986). The geochemistry of uranium and thorium in coastal marine sediments and sediment pore waters. Geochimica et Cosmochimica Acta, 50(5), 663-680. https://doi.org/10.1016/0016-7037(86)90344-3

Colbert, S. L., \& Hammond, D. E. (2008). Shoreline and seafloor fluxes of water and short-lived $\mathrm{Ra}$ isotopes to surface water of San Pedro Bay, CA. Marine Chemistry, 108(1-2), 1-17. https://doi.org/10.1016/j.marchem.2007.09.004

Corbett, D. R., Burnett, W. C., Cable, P. H., \& Clark, S. B. (1997). Radon tracing of groundwater input into Par Pond, Savannah River Site. Journal of Hydrology, 203, 209-227.

Couture, N. J., Irrgang, A., Pollard, W., Lantuit, H., \& Fritz, M. (2018). Coastal Erosion of Permafrost Soils Along the Yukon Coastal Plain and Fluxes of Organic Carbon to the Canadian Beaufort Sea. Journal of Geophysical Research: Biogeosciences, 123(2), 406-422. https://doi.org/10.1002/2017JG004166

Dimova, N. T., \& Burnett, W. C. (2011). Evaluation of groundwater discharge into small lakes based on the temporal distribution of radon-222. Limnology and Oceanography, 56(2), 486-494. https://doi.org/10.4319/1o.2011.56.2.0486

Dimova, N. T., Burnett, W. C., Chanton, J. P., \& Corbett, J. E. (2013). Application of radon-222 to investigate groundwater discharge into small shallow lakes. Journal of Hydrology, 486, 112122. https://doi.org/10.1016/j.jhydrol.2013.01.043

Dulaiova, H., Camilli, R., Henderson, P. B., \& Charette, M. A. (2010). Coupled radon, methane and nitrate sensors for large-scale assessment of groundwater discharge and non-point source pollution to coastal waters. Journal of Environmental Radioactivity, 101(7), 553-563. https://doi.org/10.1016/j.jenvrad.2009.12.004

Elsinger, R. J., \& Moore, W. S. (1984). 226Ra and 228Ra in the mixing zones of the Pee Dee River-Winyah Bay, Yangtze River and Delaware Bay Estuaries. Estuarine, Coastal and Shelf Science, 18(6), 601-613. https://doi.org/10.1016/0272-7714(84)90033-7

Hancock, G. J., Webster, I. T., Ford, P. W., \& Moore, W. S. (2000). Using Ra isotopes to examine transport processes controlling benthic fluxes into a shallow estuarine lagoon. Geochimica et Cosmochimica Acta, 64(21), 3685-3699. https://doi.org/10.1016/S00167037(00)00469-5 
Holgerson, M. A., \& Raymond, P. A. (2016). Large contribution to inland water CO2 and CH4 emissions from very small ponds. Nature Geoscience, 9(3), 222-226.

https://doi.org/10.1038/ngeo2654

Holmes, R. M., Coe, M. T., Fiske, G. J., Gurtovaya, T., McClelland, J. W., Shiklomanov, A. I., et al. (2012). Climate Change Impacts on the Hydrology and Biogeochemistry of Arctic Rivers. In C. R. Goldman, M. Kumagai, \& R. D. Robarts (Eds.), Climatic Change and Global Warming of Inland Waters: Impacts and Mitigation for Ecosystems and Societies (pp. 1-26). Wiley. https://doi.org/10.1002/9781118470596.ch1

IPCC. (2014). Climate Change 2014: Synthesis Report; Chapter Observed Changes and their Causes. IPCC. Geneva, Switzerland. https://doi.org/10.1046/j.1365-2559.2002.1340a.X

Jakobsson, M. (2002). Hypsometry and volume of the Arctic Ocean and its constituent seas. Geochemistry, Geophysics, Geosystems, 3(5), 1-18. https://doi.org/10.1029/2001GC000302

Jeffrey, L. C., Maher, D. T., Santos, I. R., Call, M., Reading, M. J., Holloway, C., \& Tait, D. R. (2018). The spatial and temporal drivers of pCO2, pCH4 and gas transfer velocity within a subtropical estuary. Estuarine, Coastal and Shelf Science, 208, 83-95. https://doi.org/10.1016/j.ecss.2018.04.022

Jungclaus, J. H., Haak, H., Latif, M., \& Mikolajewicz, U. (2005). Arctic-North Atlantic interactions and multidecadal variability of the meridional overturning circulation. Journal of Climate, 18(19), 4013-4031. https://doi.org/10.1175/JCLI3462.1

Key, R. M., Brewer, R. L., Stockwell, J. H., Guinasso, N. L., \& Schink, D. R. (1979). Some improved techniques for measuring radon and radium in marine sediments and in seawater. Marine Chemistry, 7(3), 251-264. https://doi.org/10.1016/0304-4203(79)90042-2

Kipp, L. E., Charette, M. A., Moore, W. S., Henderson, P. B., \& Rigor, I. G. (2018). Increased fluxes of shelf-derived materials to the central Arctic Ocean. Science Advances, 4(1), 1-10. https://doi.org/10.1126/sciadv.aao1302

Kipp, L. E., Spall, M. A., Pickart, R. S., Kadko, D. C., Moore, W. S., Dabrowski, J. S., \& Charette, M. A. (2020). Observational and Modeling Evidence of Seasonal Trends in SedimentDerived Material Inputs to the Chukchi Sea. Journal of Geophysical Research: Oceans, 125(5), 1-13. https://doi.org/10.1029/2019jc016007

Ku, T. L., \& Luo, S. (2008, January 1). Chapter 9 Ocean Circulation/Mixing Studies with DecaySeries Isotopes. Radioactivity in the Environment. Elsevier. https://doi.org/10.1016/S15694860(07)00009-5

Lecher, A. L. (2017). Groundwater Discharge in the Arctic: A Review of Studies and Implications for Biogeochemistry. Hydrology, 4(3), 41. https://doi.org/10.3390/hydrology4030041

Lecher, A. L., Kessler, J., Sparrow, K., Garcia-Tigreros Kodovska, F., Dimova, N., Murray, J., et al. (2016). Methane transport through submarine groundwater discharge to the North Pacific and 
Arctic Ocean at two Alaskan sites. Limnology and Oceanography, 61, S344-S355. https://doi.org/10.1002//no.10118

Lee, S. H., Stockwell, D., \& Whitledge, T. E. (2010). Uptake rates of dissolved inorganic carbon and nitrogen by under-ice phytoplankton in the Canada Basin in summer 2005. Polar Biology, 33(8), 1027-1036. https://doi.org/10.1007/s00300-010-0781-4

Lewis, K. M., van Dijken, G. L., \& Arrigo, K. R. (2020). Changes in phytoplankton concentration now drive increased Arctic Ocean primary production. Science (New York, N.Y.), 369(6500), 198-202. https://doi.org/10.1126/science.aay8380

Lin, P., Pickart, R. S., Moore, G. W. K., Spall, M. A., \& Hu, J. (2019). Characteristics and dynamics of wind-driven upwelling in the Alaskan Beaufort Sea based on six years of mooring data. Deep-Sea Research Part II: Topical Studies in Oceanography, 162, 79-92. https://doi.org/10.1016/j.dsr2.2018.01.002

Macdonald, R. W., \& Thomas, D. J. (1991). Chemical interactions and sediments of the western Canadian Arctic Shelf. Continental Shelf Research, 11(8-10), 843-863. https://doi.org/10.1016/0278-4343(91)90082-H

McClelland, J. W., Holmes, R. M., Dunton, K. H., \& Macdonald, R. W. (2012). The Arctic Ocean Estuary. Estuaries and Coasts, 35(2), 353-368. https://doi.org/10.1007/s12237-010-93573

Moore, W. S. (2000a). Ages of continental shelf waters determined from 223Ra and 224Ra. Journal Geophysical Research, 105, 117-122. https://doi.org/10.1029/1999JC000289

Moore, W. S. (2000b). Ages of continental shelf waters determined from 223Ra and 224Ra. Journal of Geophysical Research: Oceans, 105(C9), 22117-22122. https://doi.org/10.1029/1999JC000289

Moore, W. S. (2008). Fifteen years experience in measuring 224Ra and 223Ra by delayedcoincidence counting. Marine Chemistry, 109(3-4), 188-197. https://doi.org/10.1016/j.marchem.2007.06.015

Moore, W. S., Demaster, D. J., Joseph, M., Mckee, B. A., \& Swarzenski, P. W. (1996). Radionuclide tracers of sediment-water interactions on the Amazon shelf. Continental Shelf Research, 16(5), 645-665.

Moore, W. S., Blanton, J. O., \& Joye, S. B. (2006). Estimates of flushing times, submarine groundwater discharge, and nutrient fluxes to Okatee Estuary, South Carolina. Journal of Geophysical Research: Oceans, 111(9), 1-14. https://doi.org/10.1029/2005JC003041

Moore, W. S., Humphries, M. S., Benitez-Nelson, C. R., Pillay, L., \& Higgs, C. (2019). Transport of Radium and Nutrients Through Eastern South African Beaches. Journal of Geophysical Research: Oceans, 124(3), 2010-2027. https://doi.org/10.1029/2018JC014772 
Morison, M. Q., Macrae, M. L., Petrone, R. M., \& Fishback, L. A. (2017). Seasonal dynamics in shallow freshwater pond-peatland hydrochemical interactions in a subarctic permafrost environment. Hydrological Processes, 31(2), 462-475. https://doi.org/10.1002/hyp.11043

Pacini, A., Moore, G. W. K., Pickart, R. S., Nobre, C., Bahr, F., Våge, K., \& Arrigo, K. R. (2019). Characteristics and Transformation of Pacific Winter Water on the Chukchi Sea Shelf in Late Spring. Journal of Geophysical Research: Oceans, 124(10), 7153-7177. https://doi.org/10.1029/2019JC015261

Pickart, R. S., Moore, G. W. K., Torres, D. J., Fratantoni, P. S., Goldsmith, R. A., \& Yang, J. (2009, September 17). Upwelling on the continental slope of the alaskan beaufort sea: Storms, ice, and oceanographic response. Journal of Geophysical Research: Oceans. Blackwell Publishing Ltd. https://doi.org/10.1029/2008JC005009

Pickart, R. S., Spall, M. A., Moore, G. W. K., Weingartner, T. J., Woodgate, R. A., Aagaard, K., \& Shimada, K. (2011). Upwelling in the Alaskan Beaufort Sea: Atmospheric forcing and local versus non-local response. Progress in Oceanography, 88(1-4), 78-100.

https://doi.org/10.1016/j.pocean.2010.11.005

Rainville, L., Lee, C. M., \& Woodgate, R. A. (2011). Impact of wind-driven mixing in the Arctic Ocean. Oceanography, 24(3), 136-145. https://doi.org/10.5670/oceanog.2011.65

Rutgers van der Loeff, M. M., Kühne, S., Wahsner, M., Höltzen, H., Frank, M., Ekwurzel, B., et al. (2003). 228Ra and226Ra in the Kara and Laptev seas. Continental Shelf Research, 23(1), 113-124. https://doi.org/10.1016/S0278-4343(02)00169-3

Rutgers van der Loeff, M. M., Kipp, L., Charette, M. A., Moore, W. S., Black, E., Stimac, I., et al. (2018). Radium Isotopes Across the Arctic Ocean Show Time Scales of Water Mass Ventilation and Increasing Shelf Inputs. Journal of Geophysical Research: Oceans, 123(7), 4853-4873. https://doi.org/10.1029/2018JC013888

Schuur, E. A. G., Bockheim, J., Canadell, J. G., Euskirchen, E., Field, C. B., Goryachkin, S. V, et al. (2008). Vulnerability of Permafrost Carbon to Climate Change : Implications for the Global Carbon Cycle. BioScience, 58(8), 701-714.

Schuur, E. A. G., McGuire, A. D., Schädel, C., Grosse, G., Harden, J. W., Hayes, D. J., et al. (2015). Climate change and the permafrost carbon feedback. Nature, 520, 171-179. https://doi.org/10.1038/nature14338

Shen, Y., Benner, R., Robbins, L. L., \& Wynn, J. G. (2016). Sources, Distributions, and Dynamics of Dissolved Organic Matter in the Canada and Makarov Basins. Frontiers in Marine Science, 3. https://doi.org/10.3389/fmars.2016.00198

Tremblay, J. É., Michel, C., Hobson, K. A., Gosselin, M., \& Price, N. M. (2006). Bloom dynamics in early opening waters of the Arctic Ocean. Limnology and Oceanography, 51(2), 900-912. https://doi.org/10.4319/lo.2006.51.2.0900 
Vieira, L. H., Achterberg, E. P., Scholten, J., Beck, A. J., Liebetrau, V., Mills, M. M., \& Arrigo, K. R. (2019). Benthic fluxes of trace metals in the Chukchi Sea and their transport into the Arctic Ocean. Marine Chemistry, 208, 43-55. https://doi.org/10.1016/j.marchem.2018.11.001

Vonk, J. E., Tank, S. E., Bowden, W. B., Laurion, I., Vincent, W. F., Alekseychik, P., et al. (2015). Reviews and syntheses: Effects of permafrost thaw on Arctic aquatic ecosystems. Biogeosciences, 12(23), 7129-7167. https://doi.org/10.5194/bg-12-7129-2015

Walter Anthony, K., Schneider von Deimling, T., Nitze, I., Frolking, S., Emond, A., Daanen, R., et al. (2018). 21st-century modeled permafrost carbon emissions accelerated by abrupt thaw beneath lakes. Nature Communications, 9(1), 3262. https://doi.org/10.1038/s41467-018-05738-9

Walvoord, M. A., \& Kurylyk, B. L. (2016). Hydrologic Impacts of Thawing Permafrost-A Review. Vadose Zone Journal, 15(6), 1-20. https://doi.org/10.2136/vzj2016.01.0010

Wik, M., Varner, R. K., Anthony, K. W., MacIntyre, S., \& Bastviken, D. (2016, February 4). Climate-sensitive northern lakes and ponds are critical components of methane release. Nature Geoscience. Nature Publishing Group. https://doi.org/10.1038/ngeo2578

Williams, W. J., \& Carmack, E. C. (2015). The "interior" shelves of the Arctic Ocean: Physical oceanographic setting, climatology and effects of sea-ice retreat on cross-shelf exchange. Progress in Oceanography, 139, 24-41. https://doi.org/10.1016/j.pocean.2015.07.008

Woo, M. K. (2012). Permafrost hydrology. Permafrost Hydrology (Vol. 9783642234). Springer. https://doi.org/10.1007/978-3-642-23462-0 
Chapter 2: Using radon to quantify groundwater discharge and methane fluxes to a shallow, tundra lake on the Yukon-Kuskokwim Delta, Alaska

\begin{abstract}
Northern lakes are a source of greenhouse gases to the atmosphere and contribute substantially to the global carbon budget. However, the sources of methane $(\mathrm{CH} 4)$ to northern lakes are poorly constrained limiting our ability to the assess impacts of future Arctic change. Here we present measurements of the natural groundwater tracer, radon, and $\mathrm{CH} 4$ in a shallow lake on the Yukon-Kuskokwim Delta, AK and quantify groundwater discharge rates and fluxes of groundwater-derived $\mathrm{CH} 4$. We found that groundwater was significantly enriched $(2000 \%)$ in radon and $\mathrm{CH} 4$ relative to lake water. Using a mass balance approach, we calculated average groundwater fluxes of $1.2 \pm 0.6$ and $4.3 \pm 2.0 \mathrm{~cm} \mathrm{~d}-1$, respectively as conservative and upper limit estimates. Groundwater $\mathrm{CH} 4$ fluxes were 7 - 24 mmol m-2 d-1 and significantly exceeded diffusive air-water $\mathrm{CH} 4$ fluxes $(1.3-2.3 \mathrm{mmol} \mathrm{m}-2 \mathrm{~d}-1)$ from the lake to the atmosphere, suggesting that groundwater is an important source of $\mathrm{CH} 4$ to Arctic lakes and may drive observed $\mathrm{CH} 4$ emissions. Isotopic signatures of $\mathrm{CH} 4$ were depleted in groundwaters, consistent with microbial production. Higher methane concentrations in groundwater compared to other high latitude lakes were likely the source of the comparatively higher $\mathrm{CH} 4$ diffusive fluxes, as compared to those reported previously in high latitude lakes. These findings indicate that deltaic lakes across warmer permafrost regions may act as important hotspots for $\mathrm{CH} 4$ release across Arctic landscapes.
\end{abstract}

This chapter was originally published in Biogeochemistry by Elsevier in 2020 and is reproduced here with their permission.

Dabrowski, J. S., Charette, M. A., Mann, P. J., Ludwig, S. M., Natali, S. M., Holmes, R. M., Schade, J. D., Powell, M., Henderson, P. H. Using radon to quantify groundwater discharge and methane fluxes to a shallow, tundra lake on the Yukon-Kuskokwim Delta, Alaska. Biogeochemistry 148, 69-89 (2020). https://doi.org/10.1007/s10533-020-00647-w 


\subsection{Introduction}

Perennially frozen ground, also known as permafrost, underlies up to $25 \%$ of the land in the Northern Hemisphere (J. Brown et al., 2002). On average, 16\% of the terrestrial permafrost landscape is covered by water (Lehner \& Döll, 2004), and in some areas, like on the YukonKuskokwim Delta in Alaska, it exceeds 30\% (US Fish \& Wildlife Service, 2002). These aquatic systems are closely linked to the terrestrial environment through hydrology. Intense Arctic warming and permafrost thaw may alter the tight connection between terrestrial and aquatic ecosystems. For example, permafrost thaw is causing changes in aquatic systems by changing transit times and shifting flow paths between organic and mineral-rich soils (Vonk et al., 2015).

Groundwater is a source of water and solutes to marine and freshwater systems. In temperate and tropical environments, groundwater discharge has been well-documented as a source of nutrients (Charette \& Buesseler, 2004; Paytan et al., 2006) and carbon (Beck et al., 2007; Kim \& Kim, 2017; Richardson et al., 2017) to surface waters. In Arctic environments, there are few studies on groundwater discharge, many of which lack information on quantified fluxes of solutes like carbon and nitrogen (see (Lecher, 2017) for a review). Permafrost limits most groundwater flow to the shallow, thawed active layer (J. R. Williams, 1970; Woo, 2012). Potential groundwater supply through sediment beds also depends on the presence or absence of continuous permafrost. Taliks - or perennially unfrozen sediments often found beneath lakes and streams - allow for groundwater exchange between a lake and underlying sediments (Woo, 2012). Expanding taliks in a warming climate are expected to enhance exchange between lakes, rivers and underlying aquifers via groundwater supply (Walvoord \& Kurylyk, 2016).

Many lakes in polar regions are known to be substantial sources of carbon to the atmosphere ((Wik et al., 2016) and references therein), which may be influenced by groundwater-surface water interactions. In addition to delivering dissolved organic carbon that can be mineralized to $\mathrm{CO}_{2}$ and $\mathrm{CH}_{4}$, groundwater may directly transport carbon dioxide $\left(\mathrm{CO}_{2}\right)$ and methane $\left(\mathrm{CH}_{4}\right)$ that was produced in active layer soils to lakes (Kling et al., 1992) where $\mathrm{CH}_{4}$ can be oxidized or released to the atmosphere. Paytan et al. quantified $\mathrm{CH}_{4}$ transport to a lake in the Arctic suggesting that carbon-rich soils in the northern latitudes, and the release of carbon from permafrost thaw, provide fuel for $\mathrm{CH}_{4}$ production (Natali et al., 2015; Paytan et al., 2015; Schuur et al., 2008). With the expected shift to greater subsurface flow due to warming combined with future permafrost thaw (Bring et al., 2016; Walvoord \& Kurylyk, 2016; Walvoord \& Striegl, 2007), groundwater may become an increasingly important source of $\mathrm{CH}_{4}$ to lakes in permafrost environments. This is important in the context of the global carbon cycle because lakes in the Arctic constitute a substantial portion of Arctic $\mathrm{CH}_{4}$ sources and represent $6 \%$ of global natural $\mathrm{CH}_{4}$ emissions (Wik et al., 2016).

In this study, we investigated the importance of groundwater as a source of $\mathrm{CH}_{4}$ to a shallow tundra lake. Radon $\left({ }^{222} \mathrm{Rn}\right)$ was used as a natural geochemical tracer of groundwater discharge (Charette et al., 2008; Dimova et al., 2013; Dimova \& Burnett, 2011), an approach that is advantageous in regions like northern wetlands because it captures groundwater flow despite 
their low landscape gradients and microtopographic features that inhibit the use of traditional hydrologic methods such as seepage meters and water table elevation measurements (Morison et al., 2017b). In contrast, ${ }^{222} \mathrm{Rn}$ allows for the integration of these heterogeneities. As radon is produced naturally from decay of uranium-series radionuclides in sediments and soils, it is an ideal tracer of all groundwater sources including those present above the permafrost in the seasonally-thawed active layer, in permafrost, and in subpermafrost aquifers (Woo, 2012). We used a mass-balance approach (Charette et al., 2008) to quantify groundwater discharge rates and estimate groundwater-derived $\mathrm{CH}_{4}$ fluxes to the lake and compared them to measured air-water diffusive fluxes and stable isotopes.

\subsection{Materials and Methods}

\subsubsection{Study site}

The study site (Fig. $1 ; 61.264^{\circ} \mathrm{N}, 163.246^{\circ} \mathrm{W}$ ) is located $93 \mathrm{~km} \mathrm{NW}$ of Bethel, AK in the Yukon Delta National Wildlife Refuge (YDNWR). Fieldwork was conducted over two field seasons from July 1 - 13, 2017 and June 30 - July 10, 2018. The majority of groundwater and lake sampling was conducted in 2017. Gas exchange coefficients and $\mathrm{CH}_{4}$ air-water fluxes were measured in 2018. Average air temperatures in this region (1981 - 2010 average for Bethel; US National Weather Service) are $-0.8^{\circ} \mathrm{C}$ annually, $-14.4{ }^{\circ} \mathrm{C}$ in January, $13.4{ }^{\circ} \mathrm{C}$ in July, with above freezing average monthly air temperatures from April to October. Annual precipitation is $\sim 470$ $\mathrm{mm}$, with $60 \mathrm{~mm}$ occurring in July on average. The average temperatures in July 2017 and 2018, respectively, were $14.4^{\circ} \mathrm{C}$ and $13.9^{\circ} \mathrm{C}$. The recorded precipitation in July 2017 was $92 \mathrm{~mm}$ and in July 2018 was $38 \mathrm{~mm}$ (US National Weather Service). The study site is located in a zone of continuous to discontinuous permafrost (J. Brown et al., 2002) that is moderate in thickness $(\sim 180 \mathrm{~m})$ (Ferrians Jr., 1965) with taliks underlying most wetlands and water bodies. Thaw depth was $30-40 \mathrm{~cm}$ in July 2017 in areas without taliks. The sediments beneath the thick organic layer in this region were deposited in the early Pleistocene (F. H. Wilson et al., 2015). This region is characterized by polygonal peat plateaus beside low-lying wetlands. The maximum elevation in this region is approximately 15 meters above sea level and the minimum elevation is approximately $8 \mathrm{~m}$. The elevation of the lake surface and neighboring peat plateaus are 13 and $15 \mathrm{~m}$, respectively.

Lakes and ponds occupy about one third of the YDNWR in surface area (US Fish \& Wildlife Service, 2002). Most lakes in this region have a maximum depth of <1-3 $\mathrm{m}$ (Bartlett et al., 1992) and range widely in surface area from several square meters to several square kilometers. The lake in this study, colloquially termed "Landing Lake," has an average depth of $0.53 \pm 0.03 \mathrm{~m}$ and a surface area of approximately $0.36 \mathrm{~km}^{2}$ and is therefore representative of the numerous small, high latitude lakes of the YDNWR. Much of the lake's watershed is in a region of the YDNWR that experienced a wildfire in 2015, as visible by satellite imagery and evident in the field by a lack of vegetation and the presence of leftover charred materials (Fig. 1). Fire frequency has been found to increase with warming in northern Alaska (Higuera et al., 2011) and on the Yukon-Kuskokwim Delta (Sae-Lim et al., 2019), and can cause permafrost thawing, 
vegetation shifts, and carbon release (Loranty et al., 2016). Although fire effects were not the focus of this study, statistical tests were performed when enough data was available, and potential implications are discussed (Section 4.1.3). Only one surface water channel was connected to Landing Lake at its southeast corner; it was $\sim 0.33 \mathrm{~m}$ wide and $\sim 0.15 \mathrm{~m}$ deep, and discharge flowed away from the lake at $0.003 \mathrm{~m}^{3} \mathrm{~s}^{-1}$.

\subsubsection{Sample collection}

Surface water and groundwater samples for all analyses were collected on July $1-12$, 2017 and June 30 - July 10, 2018 (Fig. 1, Table 1). Samples from active layer soils and lake and pond bottom sediments were collected in 2017 for analysis and incubation experiments in the laboratory. A lake sediment sample (groundwater symbol next to the weather station, Fig. 1) was collected from the top $5 \mathrm{~cm}$ using gloved hands, stored in a clean plastic bag, and frozen until analysis ( 4 months). Active layer soils $(n=4,0-30 \mathrm{~cm})$ were cored using a sharpened steel coring barrel, sample tube and hand drill, and then frozen within 48 hours of collection. Samples were thawed for biogeochemical analyses (available online: (Ludwig, Holmes, Natali, Mann, Schade, Jardine, et al., 2017)) 2 weeks after sample collection and refrozen for $\sim 4$ months before radionuclide analyses. Air temperature, wind speed and direction, and rainfall rates were collected every 12 minutes using a weather station (AcuRite 5-in-1 Weather Sensor) placed $\sim 5 \mathrm{~m}$ above the lake surface on a peninsula (Fig. 1). At each surface water and groundwater sampling event, we measured temperature, dissolved oxygen, and electrical conductivity (YSI 6-Series Sonde (2017), YSI ProPlus multiparameter probe (2018)). Instruments were calibrated immediately prior to fieldwork and in the field.

Lake water samples $(2017, n=18$, Table 1$)$ for ${ }^{222} \mathrm{Rn}$ were collected in two ways. A RAD AQUA system (Durridge Inc.; (Schubert et al., 2012)) was used for ${ }^{222} \mathrm{Rn}$ collection for 17 of the samples. One sample, WP4, was collected in a calibrated 2-L plastic bottle with no headspace that was analyzed within four hours. One 100-L surface water sample (5 20-L "cubitainers") was collected to estimate ${ }^{222} \mathrm{Rn}$ supported by its parent, ${ }^{226} \mathrm{Ra}$. At the sampling sites in both years, dissolved $\mathrm{CH}_{4}$ was collected by vigorously shaking $30-\mathrm{mL}$ of the water sample with $30-\mathrm{mL}$ of ambient air for 60 seconds. The headspace was then transferred into pre-evacuated $12-\mathrm{mL}$ Exetainer vials until slightly over-pressurized. Two separate gas samples were collected for separate analyses of $\mathrm{CH}_{4}$ concentration and $\delta^{13} \mathrm{CH}_{4}$, respectively. Samples for water isotope $\left(\delta^{2} \mathrm{H}\right.$ and $\delta^{18} \mathrm{O}$ ) analysis were also collected in 2017 in 4.5-mL glass vials with no headspace.

Groundwater samples (2017, $n=7$, Table 2) were collected from the active layer at 20-40 $\mathrm{cm}$ depth below the soil surface using a push-point piezometer (MHE Products, Inc.) and peristaltic pump with gas impermeable tubing. Groundwater samples were limited by the maximum thaw depth of $\sim 40 \mathrm{~cm}$. Samples for ${ }^{222} \mathrm{Rn}$ were collected in $250-\mathrm{mL}$ glass bottles (RAD H2O, Durridge) that were flushed by at least three volumes of sample water and then sealed with no headspace. The same sampling procedures described above for dissolved $\mathrm{CH}_{4}$ and $\delta^{2} \mathrm{H}$ and $\delta^{18} \mathrm{O}$ isotopes were used for groundwater samples. One set of water samples was also 
collected from the southeastern stream discharging Landing Lake for $\mathrm{CH}_{4}$ and water isotopes (Fig. 1, Table 1).

Spatial and temporal variation in $\mathrm{CH}_{4}$ flux was examined across Landing Lake in 2018 to provide context for groundwater fluxes of $\mathrm{CH}_{4}$. Seven chambers were deployed for a 24-hour measurement period around the lake. Gas samples from chamber headspace and dissolved surface water were collected upon chamber deployment and after 12-24 hours (Bastviken et al., 2004). Flux rates were calculated from the difference in initial and final concentrations of $\mathrm{CH}_{4}$ in the chamber, assuming the flux decreased over time in response to a decreasing concentration gradient between the lake water and chamber headspace (Bastviken et al., 2004). To compare the impact of different flux estimate approaches, instantaneous $\mathrm{CH}_{4}$ fluxes (averaged triplicate measures, each 5 min duration) were measured during the same period. The $\mathrm{CH}_{4}$ concentrations in the chamber headspace were measured instantaneously using a Los Gatos Research Ultraportable Greenhouse Gas analyzer, and the increase in concentration over the sampling period was used to calculate chamber fluxes by fitting a linear slope to the data.

\subsubsection{Sample analysis}

\subsubsection{Radioisotopes}

Surface water measurements of ${ }^{222} \mathrm{Rn}$ were conducted in two ways. At all lake sampling locations (except WP4) ${ }^{222} \mathrm{Rn}$ was measured using a radon-in-air monitoring system (RAD7, Durridge) connected to a drying unit, spray chamber (RAD AQUA, Durridge, Inc.) and bilge pump. The temperature in the spray chamber was recorded using a stainless-steel temperature probe and data logger (HOBO U12-008, ONSET). At each station, the detector was run for $45-$ 75 minutes, including 30 minutes of equilibration. Uncertainties (standard errors) were $\sim 3 \%$ for each sample for the integrated measurement periods. The amount of ${ }^{222} \mathrm{Rn}$ in water was calculated using the measured temperature in the spray chamber and its solubility (Dimova \& Burnett, 2011). At station WP4, ${ }^{222} \mathrm{Rn}$ was measured in a 2-L sample at the field site using the Big Bottle accessory (Durridge) for the RAD7. The uncertainty or standard error for this method was $\sim 16 \%$.

Groundwater ${ }^{222} \mathrm{Rn}$ activities were measured using two different techniques. In the field, groundwater samples ( $n=7$ ) were analyzed using the RAD H2O accessory (Durridge, Inc.) within 24 hours of collection. Activities were corrected for decay between collection and measurement times. Uncertainties were $9-45 \%$ ( $1 \sigma$, standard error). To determine equilibrium ${ }^{222} \mathrm{Rn}$ activities in groundwater as additional endmembers in the model, soils $(n=4)$ and lake sediments $(n=1)$ were incubated in the laboratory (Chanyotha et al., 2014; Corbett et al., 1997). One soil sample (B2, Table 2) was collected $>5 \mathrm{~km}$ away from the lake, but was included as an endmember due to its similar bulk density to the average bulk density of all other burned soils (Table 3). Radon activities were measured using a radon emanation approach (Key et al., 1979). Efficiencies were determined using a set of radium-fiber standards containing $20 \mathrm{dpm}{ }^{226} \mathrm{Ra}$

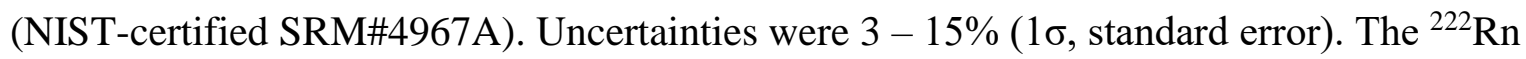


activities were converted into groundwater endmember activities using porosity and bulk density (Section 2.3.4, Table 3) (Chanyotha et al., 2014).

Experiments in the laboratory were carried out with lake bottom sediments to determine the diffusive flux of ${ }^{222} \mathrm{Rn}$ to the lake. Wet sediments were incubated in gas tight flasks with air stones and radium-free water and connected in a closed loop with two charcoal columns as described by Chanyotha et al. (2016). Radon activities were monitored for $10-20$ hours. The exponential ingrowth of ${ }^{222} \mathrm{Rn}$ activity was linearly approximated (errors of $4-10 \%$ at $10-25$ hours) (Chanyotha et al., 2016). This slope was used to calculate the diffusive flux of ${ }^{222} \mathrm{Rn}$. Leakage of the system over 20 hours was corrected for using a radium-fiber standard containing $20 \mathrm{dpm}{ }^{226} \mathrm{Ra}$. A second method was used in which lake bottom sediments were incubated and analyzed with the radon emanation approach described above (Chanyotha et al., 2014; Corbett et al., 1997; Key et al., 1979). The total equilibrium ${ }^{222} \mathrm{Rn}$ activity was multiplied by the decay constant and normalized to the area of the flask to obtain an estimate of the diffusive flux of ${ }^{222} \mathrm{Rn}$ to overlying water. The standard error of 3 trials was reported as the uncertainty. Blanks were run using the same experimental setups and subtracted from any reported values.

To determine the amount of ${ }^{226} \mathrm{Ra}$ dissolved in the Landing Lake that was supporting ${ }^{222} \mathrm{Rn}$ in the water column, the $\sim 100-\mathrm{L}$ sample was filtered onsite at $<1 \mathrm{~L} \mathrm{~min}^{-1}$ through a Mnimpregnated acrylic fiber to extract the radium (Moore \& Reid, 1973). The fiber was analyzed for the activity of ${ }^{222} \mathrm{Rn}$ supported by ${ }^{226} \mathrm{Ra}$. The fiber was ashed, packed in a polystyrene vial, and sealed with epoxy to prevent ${ }^{222} \mathrm{Rn}$ loss (Charette et al., 2001). The activity of ${ }^{226} \mathrm{Ra}$ was measured by gamma spectrometry in a well-type germanium gamma detector (Canberra). The detector was calibrated using a ${ }^{226} \mathrm{Ra}$ standard (NIST-certified SRM\#4967A) in the same geometry as the sample. The standard error $(1 \sigma)$ was reported as the uncertainty in this measurement.

\subsubsection{Methane}

Methane concentrations were analyzed using a greenhouse gas chromatograph (Shimadzu GC-2014) at the Woods Hole Research Center, and stable carbon isotopic composition of $\mathrm{CH}_{4}$ was measured at Northumbria University using a Delta V Plus IRMS interfaced to a Trace Gas Pre-Concentrator and Gas Bench (Thermo Scientific). Each isotope measurement run contained three standards (Liso1, Tiso1, Hiso1; Isometric Instruments), run in full at the beginning and end, with individual standards interleaved throughout (precision $<0.5 \%$ ). Both $\mathrm{CH}_{4}$ concentration and isotopic signatures were blank corrected for atmospheric contamination assuming the global mean surface atmospheric $\mathrm{CH}_{4}$ concentration of $1.8 \mathrm{ppm}$ and $\delta^{13} \mathrm{C}_{-} \mathrm{CH}_{4}$ of $-47.2 \%$ (Warwick et al., 2016) and reported relative to Pee Dee Belemnite (PDB).

In 2018, air-water diffusive fluxes $\left(\mathrm{F}_{\mathrm{atm}}\right)$ of $\mathrm{CH}_{4}$ from the lake were measured directly via the instantaneous and 24-hr measurement period methods described above. From these data, we calculated the gas transfer coefficient $\left(\mathrm{k}_{\mathrm{x}}\right)$ from the following equation: 


$$
\mathrm{k}_{\mathrm{X}}\left(\mathrm{m} \mathrm{d}^{-1}\right)=\mathrm{F}_{\mathrm{atm}}\left(\mathrm{mol} \mathrm{m}^{-1} \mathrm{~d}^{-1}\right) /\left([\mathrm{X}]_{\text {water }}\left(\mathrm{mol} \mathrm{m}^{-3}\right)-[\mathrm{X}]_{\text {air }}\right),
$$

where $[\mathrm{X}]_{\text {water }}$ is the measured concentration of dissolved $\mathrm{CH}_{4}$ in the lake, and $[\mathrm{X}]_{\text {air }}$ is the concentration of $\mathrm{CH}_{4}$ expected in the lake when in equilibrium with the ambient air (Emerson \& Hedges, 2008). The equilibrium concentration of $\mathrm{CH}_{4}$ was calculated using lake temperature, ambient air $\mathrm{CH}_{4}$ concentration, and Bunsen solubility constants (Wiesenburg \& Guinasso, 1979). Two models of gas exchange coefficients $\left(\mathrm{k}_{\mathrm{x}}\right)$ (Crusius \& Wanninkhof, 2003; Holgerson \& Raymond, 2016) for the lake was used to derive air-water diffusive fluxes of $\mathrm{CH}_{4}$ concentrations for Landing Lake in 2017 given similar average wind speed observations for the two years.

\subsubsection{3 $\delta^{18} \mathrm{O}$ and $\delta^{2} \mathrm{H}$}

To examine hydrologic processes and sources of water into the lake, $\delta^{18} \mathrm{O}$ and $\delta^{2} \mathrm{H}$ stable isotope values of lake water, stream, and groundwater samples were measured at Northumbria University using a Water Isotope Analyzer (LGR LWIA-24d, San Jose, USA). Ratios were measured to a precision of $0.2 \%$ for $\delta^{2} \mathrm{H}$ and $0.03 \%$ for $\delta^{18} \mathrm{O}$ and reported relative to Vienna Standard Mean Ocean Water (VSMOW).

\subsubsection{Soil characterization}

Porosity and bulk density were measured in order to calculate equilibrium groundwater radon $\left({ }^{222} \mathrm{Rn}\right.$ ) activities (Table 3) (Chanyotha et al., 2014). Soil and sediment were sampled volumetrically, dried at $60^{\circ} \mathrm{C}$ (organic soils) or $100^{\circ} \mathrm{C}$ (sediments) for 48 hours, and bulk densities $\left(\mathrm{B}_{\mathrm{D}}\right)$ calculated as dry mass/volume. Landing Lake bottom sediment characteristics were averaged for the top $5 \mathrm{~cm}$ (measured in $0.5 \mathrm{~cm}$ intervals, (Ludwig, Holmes, Natali, Mann, Schade, \& Sae-Lim, 2017)). For porosity measurements, soils and sediments were dried in an oven at $50{ }^{\circ} \mathrm{C}$. Dry sediment/soil was gently packed into a pre-weighed, volume-calibrated test tube. Deionized water was added to the test tube until it just covered the soil surface. The mass of the dry soil and test tube was subtracted from the new mass of the test tube, soil and water. Porosity $(\varphi)$ was then calculated as follows:

$$
\varphi=\left[\text { Water added }(\mathrm{g}) / \text { Density of water }\left(\mathrm{g} \mathrm{cm}^{-3}\right)\right] / \text { Volume of soil }\left(\mathrm{cm}^{3}\right) \text {. }
$$

After measuring the equilibrium ${ }^{222} \mathrm{Rn}$ activities $\left(\mathrm{A}_{222}\right.$. TOTAL) via radon emanation (see section 2.3.1), the following equation was used to calculate groundwater $(\mathrm{GW})^{222} \mathrm{Rn}$ activities (Chanyotha et al., 2014) :

$$
\begin{aligned}
\mathrm{GW}{ }^{222} \mathrm{Rn}\left(\mathrm{dpm} \mathrm{m}^{-3}\right)= & {\left[\mathrm{A}_{222, \text { TотAL }} / \text { wet mass of soil }(\mathrm{g})\right] \cdot \mathrm{B}_{\mathrm{D}}\left(\mathrm{g} \mathrm{cm}^{-3}\right) } \\
& \cdot\left(1 \mathrm{~cm}^{3} / 1 \times 10^{-6} \mathrm{~m}^{3}\right) / \varphi .
\end{aligned}
$$

Other soil and sediment characteristics were measured (C, N, moisture, etc.) and can be found online (Ludwig, Holmes, Natali, Mann, Schade, \& Sae-Lim, 2017; Ludwig, Holmes, Natali, Mann, Schade, Jardine, et al., 2017). 


\subsubsection{Statistical analyses}

Linear regressions were fit to $\mathrm{CH}_{4}$ and water stable isotope data with a $99 \%$ confidence interval. ANOVAs were used to report $p$-values indicating the significance of the relationship. These analyses were performed across all samples and with the two groups of surface waters and groundwaters, but only statistically significant relationships $(p<0.05)$ were reported.

Although the effects of wildfires on groundwater hydrology and $\mathrm{CH}_{4}$ are beyond the scope of this study, statistical tests (t-test, two-sample, unequal variances) were performed with sample data to test the potential impacts of the 2015 wildfire. First, the relationship between fire and activities of ${ }^{222} \mathrm{Rn}$ in groundwater samples was examined across all groundwater samples taken during the field campaign, including those not adjacent to Landing Lake (Table 4). The same statistical test was performed for $\mathrm{CH}_{4}$ in burned and unburned groundwaters. The impact of fire on soil bulk density was also tested using a two-sample t-test, assuming unequal variances for soils collected in 2017 (see data online: (Ludwig, Holmes, Natali, Mann, Schade, Jardine, et al., 2017)). Only soils from peat plateaus in 2017 were included to eliminate other environmental variables.

\subsection{Results}

Water quality data from Landing Lake and nearby groundwaters are presented in Tables 1 and 2 . The conductivity of surface water and groundwater was on average $0.073 \pm 0.004$ and $0.113 \pm 0.031 \mathrm{mS} \mathrm{cm}^{-1}$, respectively. All measurements in Landing Lake indicated that it was well oxygenated and thermally well mixed. The average dissolved oxygen concentration was $11.4 \pm 0.4 \mathrm{mg} \mathrm{L}^{-1}$ (115\% saturation). Water temperatures were 15.6 to $19.9^{\circ} \mathrm{C}$ with an average of $17.9^{\circ} \mathrm{C}$. Groundwater had a lower average dissolved oxygen concentration of $3.5 \pm 0.7 \mathrm{mg} \mathrm{L}^{-1}$ and a lower average temperature of $9.9 \pm 2.0^{\circ} \mathrm{C}$. The stream outlet of Landing Lake had an intermediate dissolved oxygen concentration of $6.4 \mathrm{mg} \mathrm{L}^{-1}$ and a temperature of $8.5^{\circ} \mathrm{C}$, which was similar to that of groundwater.

\subsubsection{Radioisotopes}

Radon activities were $~ 20$ times more enriched in groundwater than in surface water samples (Tables 1 and 2). Groundwater samples in burned soils did not significantly differ with respect to ${ }^{222} \mathrm{Rn}$ compared to other soils ( $p=0.84$, Table 4). However, soils collected in 2017 (see data online: [30]), did significantly differ $(p<0.01)$ in bulk density between recently burned (mean $=0.170 \mathrm{~g} \mathrm{~cm}^{-3}, \sigma^{2}=0.024 \mathrm{~g} \mathrm{~cm}^{-3}$ ) and unburned peat plateaus soils (mean $=0.087 \mathrm{~g} \mathrm{~cm}^{-3}$, $\sigma^{2}=0.005 \mathrm{~g} \mathrm{~cm}^{-3}$ ). In the lake, ${ }^{222} \mathrm{Rn}$ activities were on average $1,400 \pm 300 \mathrm{dpm} \mathrm{m}^{-3}$ (range $=$ $570-2,700 \mathrm{dpm} \mathrm{m}^{-3}$ ) while groundwater activities were 24,000 $\pm 5,000 \mathrm{dpm} \mathrm{m}^{-3}$ (range $=1,000$ $-48,000 \mathrm{dpm} \mathrm{m}^{-3}$, Tables 1 and 2). The highest surface water activities were near the southern and western edges of the lake, and the lowest activities were in the center of the lake (Fig. 2a). The lowest radon activities in groundwater were for the three soil samples incubated in the laboratory (Table 2). The measured activity of ${ }^{226} \mathrm{Ra}$ in lake water was $24 \pm 2 \mathrm{dpm} \mathrm{m}^{-3}$ (standard error) and was a minor contributor to the ${ }^{222} \mathrm{Rn}$ inventory in the lake. The diffusive flux of ${ }^{222} \mathrm{Rn}$ from bottom sediments was $850 \pm 90 \mathrm{dpm} \mathrm{m}^{-2} \mathrm{~d}^{-1}$ and $640 \pm 90 \mathrm{dpm} \mathrm{m}^{-2} \mathrm{~d}^{-1}$ as found using the 
hourly flux method (Chanyotha et al., 2016) and equilibration method (Corbett et al., 1997), respectively. The average of the two techniques was $740 \pm 140 \mathrm{dpm} \mathrm{m}^{-2} \mathrm{~d}^{-1}$.

\subsubsection{Methane}

Like radon, dissolved $\mathrm{CH}_{4}$ was more enriched in groundwater ( 200x) than in lake water (Tables 1 and 2). Groundwater samples in burned soils did not significantly differ in dissolved $\mathrm{CH}_{4}$ compared to unburned soils ( $p=0.85$, Table 4). In the lake, $\mathrm{CH}_{4}$ varied from 0.1 to 6.1 $\mu \mathrm{mol} \mathrm{L}{ }^{-1}$ (Fig. 2b) with an average concentration of $1.8 \pm 0.5 \mu \mathrm{mol} \mathrm{L}{ }^{-1}$ (Table 1). The highest concentrations were at stations WP46 and WP47 at the southwestern edge of the lake (Fig. 2b). The lowest concentrations were in the center of the lake. Dissolved $\mathrm{CH}_{4}$ concentrations in groundwater varied over a larger range from 8 to $612 \mu \mathrm{mol} \mathrm{L} \mathrm{L}^{-1}$, and the average groundwater concentration of $\mathrm{CH}_{4}$ was $370 \pm 110 \mu \mathrm{mol} \mathrm{L}^{-1}$ (Table 1). Dissolved $\mathrm{CH}_{4}$ in the stream was $\sim 5.5$ $\mu \mathrm{mol} \mathrm{L} \mathrm{L}^{-1}$, intermediate between average lake waters and groundwaters.

Dissolved $\mathrm{CH}_{4}$ in groundwater was on average more depleted in ${ }^{13} \mathrm{C}$ than surface water ($61.9 \pm 4.4 \%$ and $-47.1 \pm 0.6 \%$, respectively; Tables 1 and 2$)$. The most depleted $\delta^{13} \mathrm{C}$ value of $51.4 \%$ in surface water was found at station WP46, coinciding with the highest concentration of $\mathrm{CH}_{4}$ observed in the lake (Fig. 2b). The stream outlet had a $\delta^{13} \mathrm{C}$ value of $-47.0 \%$, similar to lake waters. There was a significant negative relationship between $\delta^{13} \mathrm{C}$ and logged $\mathrm{CH}_{4}$ concentrations in all samples $\left(\delta^{13} \mathrm{C}=-5.98 \log \left[\mathrm{CH}_{4}, \mu \mathrm{mol} \mathrm{L}{ }^{-1}\right]-46.9 \%\right.$., $\mathrm{R}^{2}=0.729, p<0.01$, Fig. 3); however, this was largely driven by differences between lake and groundwater samples, and there was no detected relationship between $\delta^{13} \mathrm{C}$ and dissolved $\mathrm{CH}_{4}$ within each group $(p>$ $0.01)$.

In 2018, the average $\mathrm{CH}_{4}$ concentration in Landing Lake was $1.1 \pm 0.4 \mu \mathrm{mol} \mathrm{L}^{-1}$ (Table 6), similar to the average in 2017 of $1.8 \pm 0.5 \mu \mathrm{mol} \mathrm{L}^{-1}$. Air-water $\mathrm{CH}_{4}$ fluxes measured using the instantaneous and 24-hr measurement period methods were $13.5 \pm 3.3 \mathrm{mmol} \mathrm{m}^{-2} \mathrm{~d}^{-1}$ and $2.7 \pm$ $1.0 \mathrm{mmol} \mathrm{m}^{-2} \mathrm{~d}^{-1}$, respectively. The calculated gas exchange coefficients, $\mathrm{k} 600$, using the instantaneous and 24-hr measurement period flux methods were $1.32 \pm 0.50 \mathrm{~m} \mathrm{~d}^{-1}$ and $0.251 \pm$ $0.014 \mathrm{~m} \mathrm{~d}^{-1}$, respectively (Table 6).

\subsection{3 $\delta^{18} \mathrm{O}$ and $\delta^{2} \mathrm{H}$}

Stable isotopes of $\mathrm{H}$ and $\mathrm{O}$ in groundwater were more depleted than lake water (Tables 1 and 2, Fig. 4). Lake water $\delta^{2} \mathrm{H}$ and $\delta^{18} \mathrm{O}$ values were $-66.8 \pm 0.2 \%$ and $-7.3 \pm 0.1 \%$, respectively, and groundwater $\delta^{2} \mathrm{H}$ and $\delta^{18} \mathrm{O}$ values were $-95.6 \pm 2.2 \%$ and $-13.5 \pm 0.3 \%$, respectively. The stream draining Landing Lake had intermediate $\delta^{2} \mathrm{H}$ and $\delta^{18} \mathrm{O}$ values, respectively, of -87.2\%o and $-11.5 \%$. When $\delta^{2} \mathrm{H}$ values were plotted as a function of $\delta^{18} \mathrm{O}$ values (Fig. 4), groundwater samples (Table 2) fell close to the Global Meteoric Water Line (Craig, 1961), and were represented by following best-fit line: $\delta^{2} \mathrm{H}_{\mathrm{H} 2 \mathrm{O}}=6.87\left(\delta^{18} \mathrm{O}\right)-2.90 \%$ o $\left(\mathrm{R}^{2}=0.70, p=0.04\right)$. Stable isotope values for all lake and pond samples collected in 2017 (see data online: (Ludwig, Holmes, Natali, Mann, Schade, Jimmie, et al., 2017)) were represented by the following relationship: $\delta^{2} \mathrm{H}_{\mathrm{H} 2 \mathrm{O}}=4.31\left(\delta^{18} \mathrm{O}\right)-36.55 \%$ o $\left(\mathrm{R}^{2}=0.96, p<<0.01\right)$. Landing Lake surface water 
samples fell below the GMWL line, but within the range of all lake samples. The stream sample was more depleted than Landing Lake surface waters and was on the line represented by all lakes and ponds.

\subsection{Discussion}

\subsubsection{Radon sources and sinks}

Consistent with previous studies, ${ }^{222} \mathrm{Rn}$ was much more enriched in groundwater than in surface water (Dimova et al., 2013; Dimova \& Burnett, 2011; Paytan et al., 2015). Groundwater ${ }^{222} \mathrm{Rn}$ activities $\left(1,000-48,000 \mathrm{dpm} \mathrm{m}^{-3}\right)$ were less than those observed in sandy, Floridian soils $\left(\sim 170,000 \mathrm{dpm} \mathrm{m}^{-3}\right)$ (Dimova et al., 2013) and in silty soils near Toolik Lake, Alaska ( 490,000 $\mathrm{dpm} \mathrm{m}^{-3}$ ) (Paytan et al., 2015). The lower activity of ${ }^{222} \mathrm{Rn}$ in soils near Landing Lake was likely due to the organic-rich soils that are low in mineral content (by weight) than most sandy or silty soils and therefore lower in its parent isotope ${ }^{238} \mathrm{U}$ that produces ${ }^{222} \mathrm{Rn}$. The surface water activities (Fig. 2a, $570-2,710 \mathrm{dpm} \mathrm{m}^{-3}$ ) were similar to those reported in a small lake in Florida $\left(1200-4800 \mathrm{dpm} \mathrm{m}^{-3}\right)$ (Dimova \& Burnett, 2011) and Toolik Lake in Alaska (2900 - $5700 \mathrm{dpm}$ $\mathrm{m}^{-3}$ ) (Paytan et al., 2015).

To quantify groundwater discharge to Landing Lake using ${ }^{222} \mathrm{Rn}$ as a tracer, we constructed a mass balance model that includes all sources and sinks of radon to the lake (Fig. 5). Similar models have been used to study groundwater discharge in both marine and lacustrine environments (Corbett et al., 1997; Dimova et al., 2013; Dimova \& Burnett, 2011; Dulaiova et al., 2010). The spatial and temporal heterogeneity of groundwater discharge precludes direct quantification; therefore, we use a "flux-by-difference" approach (Charette et al., 2008). Assuming steady state over a few weeks, the change in ${ }^{222} \mathrm{Rn}$ over time should be equal to zero, and the sources must be balanced by the sinks:

$$
0=d^{222} R n / d t\left(d p m m^{-2} d^{-1}\right)=F_{222, G W}+F_{226}+F_{\text {benthic }}-F_{a t m}-\lambda \cdot I_{222}-F_{\text {stream }}-F_{\text {recharge }} .
$$

The sources in this equation other than groundwater $\left(\mathrm{F}_{222, \mathrm{GW}}\right)$ of ${ }^{222} \mathrm{Rn}$ include alpha-decay of ${ }^{226} \mathrm{Ra}$ in the water column $\left(\mathrm{F}_{226}\right)$ and diffusive inputs from lake bottom sediments ( $\left.\mathrm{F}_{\text {benthic }}\right)$. We found no surface water streams entering the lake. The sinks in this model include loss to the atmosphere via gas exchange $\left(\mathrm{F}_{\mathrm{atm}}\right)$, decay $\left(\mathrm{t}_{1 / 2}=3.82\right.$ days $)$, which is equivalent to the inventory of ${ }^{222} \mathrm{Rn}\left(\mathrm{I}_{222}\right)$ multiplied by its decay constant $\left(\lambda=0.181\right.$ days $\left.^{-1}\right)$, and loss via the stream draining Landing Lake $\left(\mathrm{F}_{\text {stream }}\right)$. Recharge of lake water into downgradient soils and sediments ( $F_{\text {recharge }}$ ) was not measured, although its potential impact on the mass balance is discussed below. Sources of uncertainty for each mass balance model term are described in Table 7. Generally, the largest sources of uncertainty in ${ }^{222} \mathrm{Rn}$ mass balances are natural variability in endmember ${ }^{222} \mathrm{Rn}$ activities and atmospheric evasion, as well as mixing with offshore waters for coastal zones (Burnett et al., 2007). 


\subsubsection{Sinks of ${ }^{222} \mathrm{Rn}$ : gas exchange, decay, streams, and recharge}

To determine the loss of radon via gas exchange, two empirical models were compared to field measurements of the gas exchange coefficient at Landing Lake. The air-water flux of radon was calculated using Equation 1 (Emerson \& Hedges, 2008). In this case, $[\mathrm{X}]_{\text {water }}$ and $[\mathrm{X}]_{\text {air }}$ are the activities of radon measured in the lake and the activity expected when the lake is in equilibrium with the atmosphere, respectively. We assumed that atmospheric ${ }^{222} \mathrm{Rn}$ was negligible relative to the lake ${ }^{222} \mathrm{Rn}\left([\mathrm{X}]_{\mathrm{air}}=0\right)$. The gas exchange coefficient, $\mathrm{k}_{\mathrm{Rn}}$, was first estimated based on relationships to temperature (Wanninkhof, 1992) and wind speed (Crusius \& Wanninkhof, 2003). For this mass balance, we used the linear relationship for the $\mathrm{SF}_{6}$ gas exchange coefficient as a function of wind speed $\left(0-5 \mathrm{~m} \mathrm{~s}^{-1}, 20^{\circ} \mathrm{C}\right)$ for a lake similar in surface area $\left(0.13 \mathrm{~km}^{2}\right)$ to Landing Lake $\left(0.36 \mathrm{~km}^{2}\right)$ (Crusius \& Wanninkhof, 2003). Then, $\mathrm{k}_{\mathrm{SF} 6}(\mathrm{n}=14$, (Crusius \& Wanninkhof, 2003)) was converted to $\mathrm{k}_{\mathrm{Rn}}$ for the average water temperature in this study $\left(17.9 \pm 0.3^{\circ} \mathrm{C}\right)$ using the appropriate Schmidt numbers $\left(\mathrm{Sc}\left(\mathrm{SF}_{6}, 20^{\circ} \mathrm{C}\right)=956, \mathrm{Sc}(\mathrm{Rn}, 20\right.$ $\left.\left.{ }^{\circ} \mathrm{C}\right)=883, \operatorname{Sc}\left(\operatorname{Rn}, 17.9^{\circ} \mathrm{C}\right)=991\right)$ (Crusius \& Wanninkhof, 2003; Wanninkhof, 1992). This resulted in the following best-fit linear relationship as a function of wind speed, $u: \mathrm{k}_{\mathrm{Rn}}\left(17.9^{\circ} \mathrm{C}, \mathrm{m}\right.$ $\left.\mathrm{d}^{-1}\right)=0.28 \cdot u\left(\mathrm{~m} \mathrm{~s}^{-1}\right)-0.13$, which had a slope error of $19 \%$, similar to the $20 \%$ error that is typical for empirical wind-speed relationships (Dimova \& Burnett, 2011). We used the average water temperature $\left(17.9 \pm 0.3{ }^{\circ} \mathrm{C}, \mathrm{n}=18\right)$ and wind speed $\left(3.83 \pm 0.05 \mathrm{~m} \mathrm{~s}^{-1}, \mathrm{n}>1000\right)$ over the 12-day study period, which resulted in an average gas exchange coefficient of $\mathrm{k}_{\mathrm{Rn}}=1.1 \pm 0.2 \mathrm{~m} \mathrm{~d}^{-1}$ and atmospheric flux ( $\mathrm{F}_{\mathrm{atm}}$ ) of 1,600 $\pm 300 \mathrm{dpm} \mathrm{m}^{-2} \mathrm{~d}^{-1}$ (upper limit of gas exchange, Fig. 6).

In another study, an empirical relationship based on surface area, rather than wind speed, across 309 small lakes and ponds over a range of latitudes was used to estimate gas exchange (Holgerson \& Raymond, 2016). To apply this to Landing Lake, we used the gas exchange coefficient for surface areas of $0.1-1 \mathrm{~km}^{2}\left(\mathrm{k}_{600}=0.80 \mathrm{~m} \mathrm{~d}^{-1}\right)$ (Holgerson \& Raymond, 2016) and the Schmidt number for radon at the average lake temperature of $17.9 \pm 0.3{ }^{\circ} \mathrm{C}(\mathrm{Sc}=991)$ (Wanninkhof, 1992) to obtain a second estimate for the gas exchange coefficient of $\mathrm{k}_{\mathrm{Rn}}=0.62 \mathrm{~m}$ $\mathrm{d}^{-1}$. This produced a lower estimated atmospheric flux $\left(\mathrm{F}_{\mathrm{atm}}\right)$ of $900 \pm 200 \mathrm{dpm} \mathrm{m}^{-2} \mathrm{~d}^{-1}$ (lower limit, Fig. 6).

We compared these literature-derived estimates of the gas transfer coefficient with those obtained from direct measurements of gas exchange in 2018 on Landing Lake via 2-min (instantaneous) and 24-hr measurement floating chambers (Sections 2.2, 2.3.2, Table 6). The coefficients $\left(\mathrm{k}_{600}, 12.5^{\circ} \mathrm{C}\right)$ were $1.3 \pm 0.5$ and $0.25 \pm 0.01 \mathrm{~m} \mathrm{~d}^{-1}$, respectively, according to each method. When the coefficients were converted for radon at the average lake temperature in 2017, it resulted in values of $1.0 \pm 0.4$ and $0.20 \pm 0.01 \mathrm{~m} \mathrm{~d}^{-1}$, respectively for $\mathrm{k}_{\mathrm{Rn}}\left(17.9^{\circ} \mathrm{C}\right) . \mathrm{CH}_{4}$ concentrations and weather conditions were similar in 2017 and 2018, so we expect these gas exchange coefficients to apply to both years. The instantaneous method resulted in gas transfer coefficients similar to the wind speed model, but was likely influenced by ebullition, resulting in overestimates of the diffusive flux, and thus the gas transfer coefficient. The 24-hr measurement period fluxes were less than both the surface area model and wind speed model, which may have 
been due to the lower temperature of Landing Lake in 2018 compared to 2017 and the shielding of surface water from wind due to the chamber. To encompass uncertainty due to gas exchange in the ${ }^{222} \mathrm{Rn}$ mass balance, we used the surface area model as a conservative estimate and the wind speed model as an upper limit estimate of groundwater fluxes.

To calculate radon loss from the lake due to decay, we first estimated the inventory of radon in the lake by multiplying the average depth $(0.53 \pm 0.03 \mathrm{~m})$ by the average activity of ${ }^{222} \mathrm{Rn}$ in the lake $\left(1400 \pm 300 \mathrm{dpm} \mathrm{m}^{-3}\right.$, Table 1$)$. The flux due to decay is the product of this inventory and the decay constant $\left(\lambda \cdot \mathrm{I}_{222}\right)$, and was equal to $130 \pm 10 \mathrm{dpm} \mathrm{m}^{-2} \mathrm{~d}^{-1}$ (Fig. 6). Of the combined sinks for ${ }^{222} \mathrm{Rn}$, decay accounted for $8 \pm 1 \%$ and $13 \pm 1 \%$, while atmospheric exchange was $92 \pm 18 \%$ and $87 \pm 17 \%$ of total losses of ${ }^{222} \mathrm{Rn}$, for the upper limit and conservative gas exchange estimates, respectively.

We were not able to directly measure the loss of ${ }^{222} \mathrm{Rn}$ due to recharge or the single stream outlet. However, if we assume negligible evaporation and negligible stream outflow to determine the maximum impact of recharge on the mass balance, we expect that lake water would recharge into adjacent wetland areas at the same rate as groundwater influx $\left(\sim 1-4 \mathrm{~cm} \mathrm{~d}^{-}\right.$ $\left.{ }^{1}\right)$ with a ${ }^{222} \mathrm{Rn}$ activity equal to average lake water $\left(1400 \mathrm{dpm} \mathrm{m}^{-3}\right)$. The ${ }^{222} \mathrm{Rn}$ loss rate for this process would be $20-60 \mathrm{dpm} \mathrm{m} \mathrm{m}^{-2} \mathrm{~d}^{-1}$, or only $2-3 \%$ of the combined losses due to decay and gas exchange. In the case of the stream outlet, discharge was $\sim 0.003 \mathrm{~m}^{3} \mathrm{~s}^{-1}$, which is equivalent to $0.07 \mathrm{~cm} \mathrm{~d}^{-1}$ when integrated over the lake's area, as with the other mass balance terms. If the ${ }^{222} \mathrm{Rn}$ activity of the stream is assumed to be that of average lake water $\left(1400 \mathrm{dpm} \mathrm{m}^{3}\right)$, then the

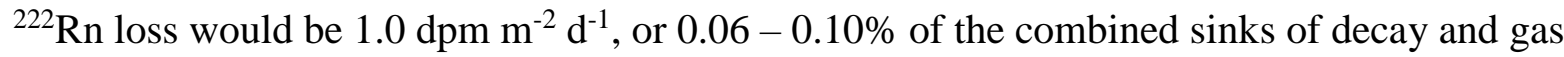
exchange. Therefore, both recharge and the stream outlet are considered negligible sinks in the ${ }^{222} \mathrm{Rn}$ mass balance, well within the uncertainty of most of the model terms (Table 7).

\subsubsection{Sources of ${ }^{222} \mathrm{Rn}$ : dissolved ${ }^{226} \mathrm{Ra}$, sediments, groundwater}

Potential sources of ${ }^{222} \mathrm{Rn}$ in this system other than groundwater are production via decay of dissolved ${ }^{226} \mathrm{Ra}$ and diffusive inputs from bottom sediments (Fig. 5). We first calculated the dissolved inventory of ${ }^{226} \mathrm{Ra}$ by multiplying the measured activity of ${ }^{226} \mathrm{Ra}$ in the lake (24 $\mathrm{dpm} \mathrm{m}{ }^{-}$ ${ }^{3}$ ) by the average depth $(0.53 \mathrm{~m})$. The inventory of ${ }^{222} \mathrm{Rn}$ supported by ${ }^{226} \mathrm{Ra}$ is equivalent to the dissolved inventory of ${ }^{226} \mathrm{Ra}\left(12 \pm 1 \mathrm{dpm} \mathrm{m}^{-2}\right)$ multiplied by the decay constant of ${ }^{222} \mathrm{Rn}$. This results in a flux $\left(\mathrm{F}_{226}\right)$ of $30 \pm 2 \mathrm{dpm} \mathrm{m}^{-2} \mathrm{~d}^{-1}$ (Fig. 6). In our steady state model where we assume that sources are equal to sinks, the input of ${ }^{222} \mathrm{Rn}$ from ${ }^{226} \mathrm{Ra}$ can only account for $2-3 \%$ of the radon inputs to the lake, consistent with other lake ${ }^{222} \mathrm{Rn}$ budgets (Corbett et al., 1997; Dimova et al., 2013).

The diffusive input of ${ }^{222} \mathrm{Rn}$, which was measured in the laboratory using Landing Lake sediments, agreed well between the two methods. The short-term measurement over $10-20$ hours resulted in a greater flux than the equilibration method, likely due to the larger concentration gradient between sediment and overlying water for shorter incubation periods. Because the short-term measurement approximates the decay as a linear function, up to $10 \%$ 
error is expected in addition to any experimental error. In the mass balance, we used the average of the two techniques $\left(740 \pm 140 \mathrm{dpm} \mathrm{m}^{-2} \mathrm{~d}^{-1}\right)$ for the sediment-water diffusive flux (Fig. 6). The flux was less than that of freshwater lake sediments from Cambodia $\left(2040 \mathrm{dpm} \mathrm{m}^{-2} \mathrm{~d}^{-1}\right)$ (Chanyotha et al., 2016), although this is expected because radon is derived from natural uranium in minerals (Charette et al., 2008), and the lake sediments in the YDNWR have a low mineral content. The ${ }^{222} \mathrm{Rn}$ diffusive flux accounted for 42 and $72 \%$ of sources in the radon budget for the upper limit and conservative estimates, respectively (Fig. 6). This contribution from diffusion is higher than most lake budgets (Dimova et al., 2013, 2015); since Landing Lake is only $\sim 0.5 \mathrm{~m}$ deep, the ratio of bottom sediment area to lake volume is relatively large, which likely explains why diffusion is estimated to be a major contributor to the Landing Lake ${ }^{222} \mathrm{Rn}$ inventory.

Together, diffusive inputs and dissolved ${ }^{226} \mathrm{Ra}$ decay account for 44 to $73 \%$ of the sources in the mass balance. Assuming negligible transport of ${ }^{222} \mathrm{Rn}$ out of Landing Lake via recharge and streams (Section 4.1.1), groundwater must be the missing source that contributes 27 to $56 \%$ of radon to the lake inventory (Fig. 6).

\subsubsection{Quantifying groundwater fluxes}

With measurements of groundwater endmembers, one can convert the ${ }^{222} \mathrm{Rn}$ fluxes into groundwater fluxes and volumetric discharge estimates. The remaining $25 \pm 10$ to $58 \pm 24 \%$ of the ${ }^{222} \mathrm{Rn}$ inventory was $300 \pm 100$ to $1000 \pm 400 \mathrm{dpm} \mathrm{m}^{-2} \mathrm{~d}^{-1}$, for the conservative and upper limit estimates, respectively (Fig. 6). In the following equation (Charette et al., 2008),

$$
\mathrm{F}_{\mathrm{GW}}\left(\mathrm{m} \mathrm{d}^{-1}\right)=\mathrm{F}_{222, \mathrm{GW}}\left(\mathrm{dpm} \mathrm{m}{ }^{-2} \mathrm{~d}^{-1}\right) / \mathrm{A}_{\mathrm{GW}}\left(\mathrm{dpm} \mathrm{m}^{-3}\right),
$$

$\mathrm{F}_{222, \mathrm{GW}}$ is the flux of ${ }^{222} \mathrm{Rn}$ via groundwater and $\mathrm{A}_{\mathrm{GW}}$ is the activity of ${ }^{222} \mathrm{Rn}$ in groundwater. There is a significant amount of variability in the groundwater samples when considering both field samples and incubations. ${ }^{222} \mathrm{Rn}$ activities in groundwater at Landing Lake are likely controlled by the mineral content of soils, which is known to increase with depth in peatlands (Morison et al., 2017a). Using the average endmember (Table 2, 24,000 $\pm 5,000 \mathrm{dpm} \mathrm{m}^{-3}$ ), the ${ }^{222} \mathrm{Rn}$ flux via groundwater ( $300 \pm 100$ to $\left.1000 \pm 400 \mathrm{dpm} \mathrm{m}^{-2} \mathrm{~d}^{-1}\right)$ and Equation 3, we calculated groundwater fluxes of $0.012 \pm 0.006$ and $0.043 \pm 0.020 \mathrm{~m} \mathrm{~d}^{-1}\left(1.2 \pm 0.6,4.3 \pm 2.0 \mathrm{~cm} \mathrm{~d}^{-1}\right.$, Table 5 ), respectively, for conservative and upper limit estimates. If we use the highest activity endmember $\left(48,000 \mathrm{dpm} \mathrm{m}^{-3}\right.$ ), the groundwater flux is $0.6 \pm 0.3$ to $2.1 \pm 0.9 \mathrm{~cm} \mathrm{~d}^{-1}$ (Table 5), for conservative and upper limit estimates, respectively. Since these groundwater fluxes were calculated using the average ${ }^{222} \mathrm{Rn}$ inventory for the whole lake surface, they represent inflow averaged over the lake's area. We only have one sample for lake bottom sediment porewater $\left({ }^{222} \mathrm{Rn}=38,000 \mathrm{dpm} \mathrm{m}^{-3}\right)$ that may be representative of possible subpermafrost groundwater, which is higher in activity that the average groundwater endmember. If subpermafrost groundwater were a significant source of water to this lake, it would likely have a ${ }^{222} \mathrm{Rn}$ activity similar to that of our porewater sample, which is greater than our average groundwater endmember but less than the highest activity endmember; therefore, it would not impact our 
estimate of ${ }^{222} \mathrm{Rn}$-based groundwater discharge fluxes. Another factor that could influence these groundwater fluxes is the impact of the 2015 wildfire. Fire did not seem to have a significant impact on ${ }^{222} \mathrm{Rn}$ activities in groundwater, but it did result in significantly higher bulk densities (Table 3). Higher soil density usually lowers hydraulic conductivity, which could cause the groundwater fluxes to be lower in fire-affected areas of the watershed. A dedicated process study would be needed to truly determine the environmental impacts of fire on groundwater hydrology.

The volumetric input of groundwater to the lake of 4,000 $\pm 2,000$ to $15,000 \pm 7000 \mathrm{~m}^{3} \mathrm{~d}^{-1}$ was estimated by multiplying the groundwater flux $\left(1.2 \pm 0.6\right.$ to $\left.4.3 \pm 2.0 \mathrm{~cm} \mathrm{~d}^{-1}\right)$ by the lake area $\left(3.6 \times 10^{5} \mathrm{~m}^{2}\right)$. Such a discharge rate would flush the lake about $3-7 \%$ by volume per day, equivalent to a residence time of $15-53$ days (Table 2). For lakes in the US with depths $<2 \mathrm{~m}$, residence times on average are $30-300$ days (Brooks et al., 2014), which agrees well with the residence times calculated here.

Unless the lake volumes were increasing over the study period, any groundwater inputs to the lake must be lost to surface water flow, wetland recharge, or evaporation. Surface water flow was estimated to drain only $0.5 \%$ of Landing Lake's volume per day, and we had no means to quantify recharge from the lake to the subsurface. If the talik beneath the lake does not penetrate the permafrost completely, the main recharge pathway for water flow would be through the wetland areas near the lake, visible as a darker green color just north and west of the lake (Fig. 1), or through outlet streams. The elevation difference between the plateaus and low-lying areas, such as the lake surface and wetlands, was approximately 2 meters, likely enough to support some level of hydrologic outflow.

Stable isotopes $\left(\delta^{18} \mathrm{O}\right.$ and $\delta^{2} \mathrm{H}$ of $\left.\mathrm{H}_{2} \mathrm{O}\right)$ provide quantitative evidence for evaporation at Landing Lake (Fig. 4). All lakes and ponds sampled in 2017 (Ludwig, Holmes, Natali, Mann, Schade, Jimmie, et al., 2017) fall on the following best-fit line: $\delta^{2} \mathrm{H}_{\mathrm{H} 2 \mathrm{O}}=4.31\left(\delta^{18} \mathrm{O}\right)-36.55 \%$ $\left(R^{2}=0.96\right)$, which we define as the Local Evaporation Line (LEL). A slope of 4.31 is within modeled slopes of $4-6$ for lakes at $60^{\circ} \mathrm{N}$ (Gibson et al., 2008) and measured slopes of $4.1-7.1$ in Canadian lakes and wetlands (Gibson et al., 2005). Landing Lake surface waters fell on the LEL and seem to be more impacted by evaporation than the majority of the lakes and ponds sampled, which is expected since Landing Lake had the highest surface area and a similar depth compared to the other sampling sites. The intersection of this evaporation line with the meteoric water line indicates the source of water to the lake (Fontes, 1980) was locally sampled active layer groundwaters. Stable isotopes in groundwaters were close to the GMWL and therefore were similar to precipitation. Another study of water stable isotopes in also found that summer precipitation was the major source of water to the active layer on the Alaskan tundra (Throckmorton et al., 2016). These data show that evaporation was a significant loss of water during the study period, although the exact percentage is not quantifiable with the available data. 


\subsubsection{Methane in Landing Lake}

Using the radon-derived groundwater fluxes $\left(\mathrm{F}_{\mathrm{GW}}=1.2 \pm 0.6\right.$ to $4.3 \pm 2.0$ and $0.6 \pm 0.3$ to $2.1 \pm 0.9 \mathrm{~cm} \mathrm{~d}^{-1}$ ) and dissolved $\mathrm{CH}_{4}$ concentration measurements, we estimated groundwater fluxes of $\mathrm{CH}_{4}$ to Landing Lake from the following equation,

$$
\mathrm{F}_{\mathrm{CH} 4, \mathrm{GW}}\left(\mathrm{mmol} \mathrm{m}^{-2} \mathrm{~d}^{-1}\right)=\mathrm{F}_{\mathrm{GW}}\left(\mathrm{m} \mathrm{d}^{-1}\right) \cdot\left[\mathrm{CH}_{4}\right]_{\mathrm{GW}}\left(\mathrm{mmol} \mathrm{m}^{-3}\right) \text {, }
$$

in which $\mathrm{F}_{\mathrm{CH} 4, \mathrm{GW}}$ is the flux of $\mathrm{CH}_{4}$ to Landing Lake via groundwater, and $\left[\mathrm{CH}_{4}\right]_{\mathrm{GW}}$ is the concentration of $\mathrm{CH}_{4}$ in groundwater (average $=370 \mu \mathrm{mol} \mathrm{L}^{-1}$ ). The groundwater flux of $\mathrm{CH}_{4}$ to Landing Lake ( $\mathrm{F}_{\mathrm{CH} 4, \mathrm{GW}}$ ) for July 2017 was $4 \pm 2$ to $16 \pm 7 \mathrm{mmol} \mathrm{m}^{-2} \mathrm{~d}^{-1}\left(\mathrm{High}^{222} \mathrm{Rn}\right.$ endmember: $2 \pm 1$ to $8 \pm 3 \mathrm{mmol} \mathrm{m}^{-2} \mathrm{~d}^{-1}$, Table 5). A study at Toolik Lake, AK conducted during July in 2011 and 2012, the same time of year as this study, included similar methods to determine radon-derived groundwater fluxes (Paytan et al., 2015). The groundwater flux of $\mathrm{CH}_{4}$ to Landing Lake is an order of magnitude greater than to Toolik Lake (Table 5, $0.1-0.7 \mathrm{mmol}$ $\mathrm{m}^{-2} \mathrm{~d}^{-1}$ ), despite having similar groundwater fluxes (Table 5, $1.2 \pm 0.6$ to $4.3 \pm 2.0 \mathrm{~cm} \mathrm{~d}^{-1}$ at Landing Lake; $0.5-2.3 \mathrm{~cm} \mathrm{~d}^{-1}$ at Toolik Lake). This is largely due to the greater Landing Lake groundwater $\mathrm{CH}_{4}$ concentrations $\left(370 \mu \mathrm{mol} \mathrm{L}^{-1}\right)$ compared to Toolik $\left(21 \mu \mathrm{mol} \mathrm{L} \mathrm{L}^{-1}\right)$. These higher fluxes may lead to the observed higher surface water dissolved $\mathrm{CH}_{4}$ in Landing Lake than at Toolik (Table 5, $1.8 \pm 0.3 \mu \mathrm{mol} \mathrm{L}-1$ and $0.02-0.8 \mu \mathrm{mol} \mathrm{L}^{-1}$, respectively). A fraction of $\mathrm{CH}_{4}$ measured in groundwaters may be oxidized before reaching lake surface waters, and other sources of $\mathrm{CH}_{4}$, such as methanogenesis in lake sediments may drive the observed differences. Further investigation is recommended to confirm the role that groundwater plays in $\mathrm{CH}_{4}$ lake budgets.

The depleted carbon-isotopic signature of $\mathrm{CH}_{4}$ in groundwater (-61.9 $\pm 4.4 \%$, Table 2$)$ is consistent with microbial production (Hornibrook et al., 1997; M J Whiticar, 1999), and the large range in isotopic values suggests both methanogenesis and oxidation may be occurring. If oxidation is a dominant process removing $\mathrm{CH}_{4}$, it is expected that $\delta^{13} \mathrm{C}$ will increase logarithmically as $\mathrm{CH}_{4}$ decreases because lighter $\mathrm{CH}_{4}$ is preferred in the reaction (M J Whiticar, 1999; Michael J. Whiticar \& Faber, 1986), a pattern which was observed in Landing Lake between groundwater and lake water samples (Fig. 3). We assume that the highest concentration of $\mathrm{CH}_{4}$ observed in groundwater was the starting concentration and stable isotopic composition before any oxidation $\left(\left[\mathrm{CH}_{4}\right]_{\mathrm{GW}}=612 \mu \mathrm{mol} \mathrm{L}^{-1}, \delta^{13} \mathrm{C}_{\mathrm{CH} 4, \mathrm{GW}}=-65.2 \%\right.$, Table 2$)$. The final composition after oxidation was assumed to be the average concentration and stable isotope value in Landing Lake $\left(\left[\mathrm{CH}_{4}\right]_{\mathrm{LAKE}}=1.8 \mu \mathrm{mol} \mathrm{L}^{-1}, \delta^{13} \mathrm{C}_{\mathrm{CH} 4, \mathrm{LAKE}}=-47.1 \%\right.$, Table 1). Following the equation below (Michael J. Whiticar \& Faber, 1986):

$$
\delta^{13} \mathrm{C}_{\mathrm{CH} 4, \mathrm{LAKE}}=\left[\delta^{13} \mathrm{C}_{\mathrm{CH} 4, \mathrm{GW}}+1000\left(\left[\mathrm{CH}_{4}\right]_{\mathrm{LAKE}} /\left[\mathrm{CH}_{4}\right]_{\mathrm{GW}}\right)^{1 / \alpha-1}\right]-1000,
$$

The fractionation factor $(\alpha)$ between starting groundwater $\mathrm{CH}_{4}$ and average lake $\mathrm{CH}_{4}$ was 1.003 , in good agreement, considering the margin of error, with the expected $\alpha$ of $1.005-1.030$ for bacterial $\mathrm{CH}_{4}$ oxidation (M J Whiticar, 1999), which supports the idea that $\mathrm{CH}_{4}$ in the lake was 
produced in the active layer and then transported by groundwater movement, as has been qualitatively observed in other lakes and streams (Crawford et al., 2013; Kling et al., 1992).

Additionally, $\mathrm{CH}_{4}$ produced in bottom sediments may also be transported into the lake by diffusion and ebullition. Additional measurements of $\mathrm{CH}_{4}$ concentrations and $\delta^{13} \mathrm{C}_{\mathrm{CH} 4}$ in sediment porewater profiles and floating chambers would be necessary to completely quantify sediment-water diffusive fluxes and ebullitive fluxes, respectively, and their contribution to the lake's $\mathrm{CH}_{4}$ budget. Diffusion, ebullition and advection may collectively contribute to the $\mathrm{CH}_{4}$ budget, and each may be impacted by environmental changes. As precipitation increases in the Arctic (Rawlins et al., 2010; Wrona et al., 2016), groundwater flow is expected to increase, impacting advective transport of $\mathrm{CH}_{4}$ (Walvoord \& Kurylyk, 2016). Recent work has also revealed that abrupt thaw beneath Arctic lakes can accelerate carbon emissions from lakes (Walter Anthony et al., 2018), potentially increasing future diffusive and ebullitive $\mathrm{CH}_{4}$ fluxes from sediments.

Once $\mathrm{CH}_{4}$ enters a lake, it may be lost in the water column via oxidation, to the atmosphere by gas exchange, to groundwater recharge, or surface transport. We calculated diffusive air-water $\mathrm{CH}_{4}$ (Section 2.3.2), using the observed $\left(1.8 \pm 0.3 \mu \mathrm{mol} \mathrm{L}{ }^{-1}\right)$ and saturated concentrations of $\mathrm{CH}_{4}$ in the lake $\left(0.004 \mu \mathrm{mol} \mathrm{L}^{-1}\right)$ and two modeled gas exchange coefficients $\left(\mathrm{k}_{\mathrm{CH} 4}=1.36 \mathrm{~m} \mathrm{~d}^{-1}\right.$ and $0.79 \mathrm{~m} \mathrm{~d}^{-1}$, at $\left.17.9^{\circ} \mathrm{C}\right)$. The flux from Landing Lake to the atmosphere for July 2017 was $1.3-2.3 \mathrm{mmol} \mathrm{m}^{-2} \mathrm{~d}^{-1}$, approximately $3-18$ times less than lake input of $\mathrm{CH}_{4}$ via groundwater (Table 5). The 24-hr measurement period $\mathrm{CH}_{4}$ fluxes in 2018 were $1.3-5.7 \mathrm{mmol}$ $\mathrm{m}^{-2} \mathrm{~d}^{-1}$ (Tables 5 and 6), which agreed well with the calculated diffusive air-water fluxes. This suggests that groundwater sources of $\mathrm{CH}_{4}$ can support all observed diffusion of $\mathrm{CH}_{4}$ from the lake surface and that they may be a driver of observed diffusive $\mathrm{CH}_{4}$ emissions.

That the groundwater fluxes of $\mathrm{CH}_{4}$ were higher than air-water diffusive losses is likely due to the additional removal of $\mathrm{CH}_{4}$ via oxidation in the water column (Bastviken et al., 2002; M J Whiticar, 1999), a determination supported by $\delta^{13} \mathrm{C}_{\mathrm{CH} 4}$ (Fig. 3). Oxidation of $\mathrm{CH}_{4}$ in the water column of freshwater lakes is expected by $\mathrm{CH}_{4}$ oxidizing bacteria (M J Whiticar, 1999) and is typically $30-99 \%$ of $\mathrm{CH}_{4}$ produced in sediments or anoxic waters (e.g. (Bastviken et al., 2002, 2008)). Typical oxidation rates can therefore account for this "missing" $\mathrm{CH}_{4}$ in Landing Lake. Climate warming will increase both methanogenesis and $\mathrm{CH}_{4}$ oxidation, but oxidation rates are typically less temperature dependent than production rates, and lower solubility of $\mathrm{CH}_{4}$ in warmer warmers may cause $\mathrm{CH}_{4}$ release via bubbles that escape oxidation (Dean et al., 2018).

The air-water diffusive flux in this study was similar to the diffusive methane flux of 2 $10 \mathrm{mmol} \mathrm{m} \mathrm{m}^{-1}$ for 38 peatland ponds across the Arctic and subarctic (Table 5) (Wik et al., 2016). Another study of 40 lakes in Alaska $\left(\sim 65^{\circ} \mathrm{N}\right)$ with similar surface areas found average airwater $\mathrm{CH}_{4}$ fluxes in summer of $0.6 \mathrm{mmol} \mathrm{m}^{-2} \mathrm{~d}^{-1}$ (Sepulveda-Jauregui et al., 2015). It is important to note that this study was done in the summer season, so these fluxes are likely to change with better temporal coverage. Polar regions are expected to become warmer (Schuur et 
al., 2008, 2015; Vihma et al., 2016) and wetter (Rawlins et al., 2010; Wrona et al., 2016) over the following decades, so higher $\mathrm{CH}_{4}$ production in soils is expected if increasing precipitation increases soil moisture (Natali et al., 2015) which can then be transported to aquatic systems by groundwater flow.

In this study, we used naturally occurring ${ }^{222} \mathrm{Rn}$ to quantify groundwater discharge and dissolved $\mathrm{CH}_{4}$ fluxes to a lake in a subarctic terrestrial wetland. Groundwater fluxes were similar to those at another lake in Alaska measured with the same radon-budget method (Paytan et al., 2015). We found that groundwater is a source of $\mathrm{CH}_{4}$ to the lake as suggested by the fact that groundwater $\mathrm{CH}_{4}$ fluxes substantially exceeded diffusive fluxes from the lake surface. The concentrations of $\mathrm{CH}_{4}$ and diffusive fluxes were higher than the well-studied Toolik Lake. Increased $\mathrm{CH}_{4}$ production with warming and wetting of the Arctic may lead to higher rates of delivery of $\mathrm{CH}_{4}$ to aquatic environments due to the combined increase in $\mathrm{CH}_{4}$ production (Natali et al., 2015) and the shift to greater subsurface flow as permafrost thaws (Walvoord \& Kurylyk, 2016).

Author Contributions: Conceptualization, J.S.D., M.A.C., R.M.H, S.M.N, J.D.S. and P.J.M.; methodology, J.S.D., M.A.C. P.J.M., and S.M.L.; validation, J.S.D. and M.A.C.; formal analysis, J.S.D., S.M.L., and M.P.; investigation, J.S.D., P.J.M, S.M.L., M.P., and P.B.H.; resources, J.S.D., P.B.H., M.A.C., R.M.H, S.M.N, J.D.S. and P.J.M.; data curation, J.S.D., S.M.L., P.J.M., and M.P.; writing — original draft preparation, J.S.D.; writing—review and editing, J.S.D, M.A.C., P.J.M, S.M.L, M.P., P.B.H, R.M.H, S.M.N, J.D.S..; visualization, J.S.D.; supervision, M.A.C.; project administration, M.A.C.; funding acquisition, M.A.C., P.J.M, R.M.H, S.M.N, J.D.S..

Conflicts of Interest: The authors declare no conflict of interest. The funders had no role in the design of the study; in the collection, analyses, or interpretation of data; in the writing of the manuscript, or in the decision to publish the results.

\section{Acknowledgements}

The authors acknowledge the help of the Polar Field Services Team and helicopter pilot, Stan Herman, for assistance and support in the field. They also thank the other Polaris 2017 and 2018 participants for field assistance, ideas, and companionship. J.S.D. thanks Laura Jardine for sharing her soil samples (B2, U1, U3, B3) (Ludwig, Holmes, Natali, Mann, Schade, Jardine, et al., 2017) and to Jordan Jimmie for stream discharge data and sampling. This work was funded by National Science Foundation awards OCE-1458305 to M.A.C., 1561437 to S.M.N, J.D.S., and R.M.H and 1624927 to S.M.N., P.J.M. and R.M.H. We thank the two reviewers for their constructive comments that improved the quality of this manuscript. 


\section{References}

Bartlett KB, Crill PM, Sass RL, et al (1992) Methane emissions from tundra environments in the Yukon-Kuskokwim delta, Alaska. J Geophys Res 97:16645-16660. doi: 10.1029/91JD00610

Bastviken D, Cole J, Pace M, Tranvik L (2004) Methane emissions from lakes: Dependence of lake characteristics, two regional assessments, and a global estimate. Global Biogeochem Cycles 18:1-12. doi: 10.1029/2004GB002238

Bastviken D, Cole JJ, Pace ML, Van de-Bogert MC (2008) Fates of methane from different lake habitats: Connecting whole-lake budgets and $\mathrm{CH} 4$ emissions. J Geophys Res Biogeosciences 113:G02024. doi: 10.1029/2007JG000608

Bastviken D, Ejlertsson J, Tranvik L (2002) Measurement of methane oxidation in lakes: A comparison of methods. Environ Sci Technol 36:3354-3361. doi: 10.1021/es010311p

Beck AJ, Tsukamoto Y, Tovar-Sanchez A, et al (2007) Importance of geochemical transformations in determining submarine groundwater discharge-derived trace metal and nutrient fluxes. Appl Geochemistry 22:477-490. doi: 10.1016/J.APGEOCHEM.2006.10.005

Bring A, Fedorova I, Dibike Y, et al (2016) Arctic terrestrial hydrology: A synthesis of processes, regional effects, and research challenges. J Geophys Res Biogeosciences 121:621649. doi: 10.1002/2015JG003131

Brooks JR, Gibson JJ, Birks SJ, et al (2014) Stable isotope estimates of evaporation : inflow and water residence time for lakes across the United States as a tool for national lake water quality assessments. Limnol Oceanogr 59:2150-2165. doi: 10.4319/lo.2014.59.6.2150

Brown J, Ferrians Jr. OJ, Heginbottom JA, Melnikov ES (2002) Circum-Arctic Map of Permafrost and Ground-Ice Conditions, version 2. National Snow and Ice Data Center

Burnett WC, Santos IR, Weinstein Y, et al (2007) Remaining uncertainties in the use of Rn-222 as a quantitative tracer of submarine groundwater discharge. In: IAHS-AISH Publication. pp $109-118$

Chanyotha S, Kranrod C, Burnett WC (2014) Assessing diffusive fluxes and pore water radon activities via a single automated experiment. J Radioanal Nucl Chem 301:581-588. doi: $10.1007 / \mathrm{s} 10967-014-3157-3$

Chanyotha S, Kranrod C, Kritsananuwat R, et al (2016) Optimizing laboratory-based radon flux measurements for sediments. J Environ Radioact 158-159:47-55. doi: 10.1016/j.jenvrad.2016.03.023

Charette M a, Moore WS, Burnett WC (2008) Uranium-and Thorium-Series Nuclides as Tracers of Submarine Groundwater Discharge. Radioact Environ 13:155-191 
Charette MA, Buesseler KO (2004) Submarine groundwater discharge of nutrients and copper to an urban subestuary of Chesapeake Bay (Elizabeth River). Limnol Oceanogr 49:376-385. doi: 10.4319/lo.2004.49.2.0376

Charette MA, Buesseler KO, Andrews JE (2001) Utility of radium isotopes for evaluating the input and transport of groundwater-derived nitrogen to a Cape Cod estuary. Limnol Oceanogr 46:465-470. doi: 10.4319/1o.2001.46.2.0465

Corbett DR, Burnett WC, Cable PH, Clark SB (1997) Radon tracing of groundwater input into Par Pond, Savannah River Site. J Hydrol 203:209-227

Craig H (1961) Isotopic Variations in Meteoric Waters. Science (80- ) 133:1702-1703. doi: 10.1126/science.133.3465.1702

Crawford JT, Striegl RG, Wickland KP, et al (2013) Emissions of carbon dioxide and methane from a headwater stream network of interior Alaska. J Geophys Res Biogeosciences 118:482494. doi: 10.1002/jgrg.20034

Crusius J, Wanninkhof R (2003) Gas transfer velocities measured at low wind speed over a lake. Limnol Oceanogr 48:1010-1017. doi: 10.4319/lo.2003.48.3.1010

Dean JF, Middelburg JJ, Röckmann T, et al (2018) Methane Feedbacks to the Global Climate System in a Warmer World. Rev Geophys 56:207-250. doi: 10.1002/2017RG000559

Dimova NT, Burnett WC (2011) Evaluation of groundwater discharge into small lakes based on the temporal distribution of radon-222. Limnol Oceanogr 56:486-494. doi:

10.4319/lo.2011.56.2.0486

Dimova NT, Burnett WC, Chanton JP, Corbett JE (2013) Application of radon-222 to investigate groundwater discharge into small shallow lakes. J Hydrol 486:112-122. doi:

10.1016/j.jhydrol.2013.01.043

Dimova NT, Paytan A, Kessler JD, et al (2015) Current Magnitude and Mechanisms of Groundwater Discharge in the Arctic: Case Study from Alaska. Environ Sci Technol 49:1203612043. doi: 10.1021/acs.est.5b02215

Dulaiova H, Camilli R, Henderson PB, Charette MA (2010) Coupled radon, methane and nitrate sensors for large-scale assessment of groundwater discharge and non-point source pollution to coastal waters. J Environ Radioact 101:553-563. doi: 10.1016/j.jenvrad.2009.12.004

Emerson SR, Hedges JI (2008) Chemical Oceanography and the Marine Carbon Cycle.

Cambridge University Press, New York

Ferrians Jr. OJ (1965) Permafrost map of Alaska. U.S. Geological Survey Miscellaneous Geologic Investigations Map 445. Scale 1:2,500,000. 1 
Fontes JC (1980) Handbook of Environmental Isotope Geochemistry. Elsevier Scientific Pub. Co., New York

Garcia-Tigreros Kodovska F, Sparrow KJ, Yvon-Lewis SA, et al (2016) Dissolved methane and carbon dioxide fluxes in Subarctic and Arctic regions: Assessing measurement techniques and spatial gradients. Earth Planet Sci Lett 436:43-55. doi: 10.1016/J.EPSL.2015.12.002

Gibson JJ, Birks SJ, Edwards TWD (2008) Global prediction of $\delta$ A and $\delta 2 H-\delta 18 \mathrm{O}$ evaporation slopes for lakes and soil water accounting for seasonality. Global Biogeochem Cycles 22:1-12. doi: 10.1029/2007GB002997

Gibson JJ, Edwards TWD, Birks SJ, et al (2005) Progress in isotope tracer hydrology in Canada. Process 19:303-327. doi: 10.1002/hyp.5766

Higuera PE, Chipman ML, Barnes JL, et al (2011) Variability of tundra fire regimes in Arctic Alaska: Millennial-scale patterns and ecological implications. Ecol Appl 21:3211-3226. doi: 10.1890/11-0387.1

Holgerson MA, Raymond PA (2016) Large contribution to inland water CO2 and CH4 emissions from very small ponds. Nat Geosci 9:222-226. doi: 10.1038/ngeo2654

Hornibrook ERC, Longstaffe FJ, Fyfe WS (1997) Spatial distribution of microbial methane production pathways in temperate zone wetland soils: Stable carbon and hydrogen isotope evidence. Geochim Cosmochim Acta 61:745-753. doi: 10.1016/S0016-7037(96)00368-7

Key RM, Brewer RL, Stockwell JH, et al (1979) Some improved techniques for measuring radon and radium in marine sediments and in seawater. Mar Chem 7:251-264. doi: 10.1016/03044203(79)90042-2

Kim J, Kim G (2017) Inputs of humic fluorescent dissolved organic matter via submarine groundwater discharge to coastal waters off a volcanic island (Jeju, Korea). Sci Rep 7:7921. doi: 10.1038/s41598-017-08518-5

Kling GW, Kipphut GW, Miller MC (1992) The flux of CO2 and CH4 from lakes and rivers in arctic Alaska. Hydrobiologia 23-36

Lecher A (2017) Groundwater Discharge in the Arctic: A Review of Studies and Implications for Biogeochemistry. Hydrology 4:41. doi: 10.3390/hydrology4030041

Lehner B, Döll P (2004) Development and validation of a global database of lakes, reservoirs and wetlands. J Hydrol 296:1-22. doi: 10.1016/J.JHYDROL.2004.03.028

Loranty MM, Lieberman-Cribbin W, Berner LT, et al (2016) Spatial variation in vegetation productivity trends, fire disturbance, and soil carbon across arctic-boreal permafrost ecosystems. Environ Res Lett 11:. doi: 10.1088/1748-9326/11/9/095008 
Ludwig S, Holmes RM, Natali SM, et al (2017a) Polaris Project 2017: Soil fluxes, carbon, and nitrogen, Yukon-Kuskokwim Delta, Alaska

Ludwig S, Holmes RM, Natali SM, et al (2017b) Polaris Project 2017: Aquatic isotopes, carbon, and nitrogen, Yukon-Kuskokwim Delta, Alaska

Ludwig S, Holmes RM, Natali SM, et al (2017c) Polaris Project 2017: Lake sediment carbon and nitrogen, Yukon-Kuskokwim Delta, Alaska

Moore WS, Reid DF (1973) Extraction of radium from natural waters using manganeseimpregnated acrylic fibers. J Geophys Res 78:8880-8886. doi: 10.1029/JC078i036p08880

Morison MQ, Macrae ML, Petrone RM, Fishback L (2017a) Capturing temporal and spatial variability in the chemistry of shallow permafrost ponds. Biogeosciences 14:5471-5485. doi: 10.5194/bg-14-5471-2017

Morison MQ, Macrae ML, Petrone RM, Fishback LA (2017b) Seasonal dynamics in shallow freshwater pond-peatland hydrochemical interactions in a subarctic permafrost environment. Hydrol Process 31:462-475. doi: 10.1002/hyp.11043

Natali SM, Schuur EAG, Mauritz M, et al (2015) Permafrost thaw and soil moisture driving CO2 and $\mathrm{CH} 4$ release from upland tundra. J Geophys Res Biogeosciences 120:1-13. doi:

10.1002/2014JG002872.Received

Paytan A, Lecher AL, Dimova N, et al (2015) Methane transport from the active layer to lakes in the Arctic using Toolik Lake, Alaska, as a case study. Proc Natl Acad Sci 112:3636-3640. doi: 10.1073/pnas.1417392112

Paytan A, Shellenbarger GG, Street JH, et al (2006) Submarine groundwater discharge: An important source of new inorganic nitrogen to coral reef ecosystems. Limnol Oceanogr 51:343348. doi: 10.4319/lo.2006.51.1.0343

Rawlins MA, Steele M, Holland MM, et al (2010) Analysis of the Arctic System for Freshwater Cycle Intensification: Observations and Expectations. J Clim 23:5715-5737. doi: 10.1175/2010JCLI3421.1

Richardson CM, Dulai H, Popp BN, et al (2017) Submarine groundwater discharge drives biogeochemistry in two Hawaiian reefs. Limnol Oceanogr 62:S348-S363. doi: 10.1002/lno.10654

Sae-Lim J, Russell JM, Vachula RS, et al (2019) Temperature-controlled tundra fire severity and frequency during the last millennium in the Yukon-Kuskokwim Delta, Alaska. Holocene. doi: $10.1177 / 0959683619838036$

Schubert M, Paschke A, Bednorz D, et al (2012) Kinetics of the water/air phase transition of radon and its implication on detection of radon-in-water concentrations: Practical assessment of 
different on-site radon extraction methods. Environ Sci Technol 46:8945-8951. doi: 10.1021/es3019463

Schuur EAG, Bockheim J, Canadell JG, et al (2008) Vulnerability of Permafrost Carbon to Climate Change : Implications for the Global Carbon Cycle. Bioscience 58:701-714

Schuur EAG, McGuire AD, Schädel C, et al (2015) Climate change and the permafrost carbon feedback. Nature 520:171-179. doi: 10.1038/nature14338

Sepulveda-Jauregui A, Walter Anthony KM, Martinez-Cruz K, et al (2015) Methane and carbon dioxide emissions from 40 lakes along a north-south latitudinal transect in Alaska.

Biogeosciences 12:3197-3223. doi: 10.5194/bg-12-3197-2015

Throckmorton HM, Newman BD, Heikoop JM, et al (2016) Active layer hydrology in an arctic tundra ecosystem: quantifying water sources and cycling using water stable isotopes. Hydrol Process 30:4972-4986. doi: 10.1002/hyp.10883

US Fish \& Wildlife Service (2002) Yukon Delta National Wildlife Refuge. In: Fact Sheet. https://www.fws.gov/uploadedFiles/Region_7/NWRS/Zone_1/Yukon_Delta/PDF/yukondelta.pd f. Accessed 24 Jul 2018

Vihma T, Screen J, Tjernström M, et al (2016) The atmospheric role in the Arctic water cycle: A review on processes, past and future changes, and their impacts. J Geophys Res Biogeosciences 121:586-620. doi: 10.1002/2015JG003132

Vonk JE, Tank SE, Bowden WB, et al (2015) Reviews and syntheses: Effects of permafrost thaw on Arctic aquatic ecosystems. Biogeosciences 12:7129-7167. doi: 10.5194/bg-12-7129-2015

Walter Anthony K, Schneider von Deimling T, Nitze I, et al (2018) 21st-century modeled permafrost carbon emissions accelerated by abrupt thaw beneath lakes. Nat Commun 9:3262. doi: 10.1038/s41467-018-05738-9

Walvoord MA, Kurylyk BL (2016) Hydrologic Impacts of Thawing Permafrost-A Review. Vadose Zo J 15:1-20. doi: 10.2136/vzj2016.01.0010

Walvoord MA, Striegl RG (2007) Increased groundwater to stream discharge from permafrost thawing in the Yukon River basin: Potential impacts on lateral export of carbon and nitrogen. Geophys Res Lett 34:. doi: 10.1029/2007GL030216

Wanninkhof R (1992) Relationship Between Wind Speed and Gas Exchange. J Geophys Res 97:7373-7382

Warwick NJ, Cain ML, Fisher R, et al (2016) Using $\delta 13 \mathrm{C}-\mathrm{CH} 4$ and $\delta \mathrm{D}-\mathrm{CH} 4$ to constrain Arctic methane emissions. Atmos Chem Phys 16:14891-14908. doi: 10.5194/acp-16-14891-2016

Whiticar MJ (1999) Carbon and hydrogen isotope systematics of bacterial formation and oxidation of methane. Chem Geol 161:291-314. doi: 10.1016/s0009-2541(99)00092-3 
Whiticar MJ, Faber E (1986) Methane oxidation in sediment and water column environments Isotope evidence. Org Geochem 10:759-768. doi: 10.1016/S0146-6380(86)80013-4

Wiesenburg DA, Guinasso NL (1979) Equilibrium solubilities of methane, carbon monoxide, and hydrogen in water and sea water. J Chem Eng Data 24:356-360. doi: 10.1021/je60083a006

Wik M, Varner RK, Anthony KW, et al (2016) Climate-sensitive northern lakes and ponds are critical components of methane release. Nat. Geosci. 9:99-105

Williams JR (1970) Ground water in the permafrost regions of Alaska

Wilson FH, Hults CP, Mull CG, Karl SM (2015) Geologic Map of Alaska. USGS Scientific Investigations Map 3340, pamphlet

Woo MK (2012) Permafrost hydrology. Springer

Wrona FJ, Johansson M, Culp JM, et al (2016) Transitions in Arctic ecosystems: Ecological implications of a changing hydrologic regime. J Geophys Res Biogeosciences 121:650-674. doi: 10.1002/2015JG003133 
Table $\mathbf{1}^{222} \mathrm{Rn}$ activities and dissolved $\mathrm{CH}_{4}$ concentrations measured at Landing Lake. Latitude (Lat) and longitude (Lon) are in decimal degrees. Depth represents depth of water sample collection. Cond. $=$ conductivity; $\delta^{13} \mathrm{C}$ of methane are presented relative to Pee Dee Belemnite (PDB). $\mathrm{H}_{2} \mathrm{O}$ stable isotopes reported relative to Vienna Standard Mean Ocean Water (VSMOW). Average value \pm standard error is reported. Stream sample not included in average.

\begin{tabular}{|c|c|c|c|c|c|c|c|c|c|c|c|c|}
\hline Station & Type & Lat. & Lon. & $\begin{array}{l}\text { Depth } \\
\mathrm{cm}\end{array}$ & $\begin{array}{c}\text { Cond } \\
\mathrm{mS} \\
\mathrm{cm}^{-1}\end{array}$ & $\begin{array}{c}\mathrm{O}_{2} \\
\\
m g \\
L^{-1}\end{array}$ & $\begin{array}{c}\text { Water } \\
\text { Temp } \\
\text { oC }\end{array}$ & $\begin{array}{c}{ }^{222} \mathrm{Rn} \\
\\
d p m \\
m^{-3}\end{array}$ & $\begin{array}{c}\mathrm{CH}_{4} \\
\mu m o l \\
L^{-1}\end{array}$ & $\begin{array}{c}\delta^{13} \mathrm{C}_{\mathrm{CH} 4} \\
\%\end{array}$ & $\begin{array}{c}\delta^{2} \mathrm{H}_{\mathrm{H} 2 \mathrm{O}} \\
\% \circ\end{array}$ & $\begin{array}{c}\delta^{18} \mathrm{O}_{\mathrm{H} 2 \mathrm{C}} \\
\% \text { o }\end{array}$ \\
\hline WP4 & Lake & 61.264 & -163.246 & 10 & $\mathrm{ND}^{\mathrm{a}}$ & ND & ND & 2700 & ND & ND & ND & ND \\
\hline WP6 & Lake & 61.265 & -163.244 & 45 & 0.133 & 14.7 & 15.7 & 2640 & ND & ND & ND & ND \\
\hline WP7 & Lake & 61.263 & -163.244 & 30 & 0.066 & 13.7 & 17.3 & 1660 & ND & ND & ND & ND \\
\hline WP8 & Lake & 61.264 & -163.243 & 30 & 0.051 & 14.9 & 15.6 & 1140 & 0.1 & -45.7 & -67.3 & -7.5 \\
\hline WP17 & Lake & 61.268 & -163.240 & 50 & 0.072 & 13.9 & 16.5 & 1350 & 1.4 & -47.2 & -67.1 & -7.1 \\
\hline WP18 & Lake & 61.267 & -163.238 & 50 & 0.067 & 10.0 & 17.4 & 1370 & 1.3 & -47.1 & -67 & -7.3 \\
\hline WP19 & Lake & 61.268 & -163.237 & 43 & 0.067 & 10.7 & 17.7 & 1051 & 1.3 & -47.0 & -67 & -7.3 \\
\hline WP20 & Lake & 61.270 & -163.237 & 40 & 0.065 & 9.5 & 17.9 & 1390 & 1.5 & -47.3 & -67.1 & -7.4 \\
\hline WP21 & Lake & 61.269 & -163.241 & 44 & 0.062 & 12.8 & 18.1 & 1080 & 1.5 & -46.3 & -67.1 & -7.3 \\
\hline WP22 & Lake & 61.268 & -163.243 & 45 & 0.062 & 9.2 & 18.3 & 1020 & 1.3 & -41.3 & -66.9 & -7.4 \\
\hline WP31 & Lake & 61.263 & -163.240 & 35 & 0.089 & 10.0 & 18.3 & 1620 & 1.5 & -48.0 & -65.7 & -7.2 \\
\hline WP32 & Lake & 61.264 & -163.239 & 35 & 0.087 & 10.3 & 18.9 & 1394 & 1.8 & -44.6 & -65.8 & -7.2 \\
\hline WP33 & Lake & 61.265 & -163.238 & 35 & 0.080 & 10.4 & 19.9 & 1008 & 1.6 & -46.0 & -65.7 & -7.2 \\
\hline WP34 & Lake & 61.266 & -163.240 & 50 & 0.077 & 11.1 & 19.4 & 570 & 1.5 & -48.7 & -65.5 & -6.5 \\
\hline WP35 & Lake & 61.267 & -163.243 & 45 & 0.072 & 11.1 & 19.7 & 1040 & 1 & -49.2 & -65.6 & -7.3 \\
\hline WP42 & Lake & 61.267 & -163.246 & 50 & 0.076 & 10.5 & 15.9 & 1550 & 1.7 & -47.8 & -67.5 & -7.5 \\
\hline WP46 & Lake & 61.265 & -163.247 & 40 & 0.058 & 10.6 & 18.9 & 1640 & 6.1 & -51.4 & -68.8 & -8.5 \\
\hline WP47 & Lake & 61.264 & -163.248 & 50 & 0.059 & 10.7 & 18.7 & 1650 & 2.9 & -48.5 & -67.9 & -7 \\
\hline Stream & Stream & 61.260 & -163.241 & 10 & 0.020 & 6.4 & 8.5 & ND & 5.5 & -47.0 & -87.2 & -11.5 \\
\hline Avg. & & & & & 0.073 & 11.4 & 17.9 & 1400 & 1.8 & -47.1 & -66.8 & $\begin{array}{l}-7.3 \\
\end{array}$ \\
\hline \pm & & & & & 0.004 & 0.4 & 0.3 & 300 & 0.5 & 0.6 & 0.2 & 0.1 \\
\hline
\end{tabular}

${ }^{\mathrm{a}} \mathrm{ND}=$ no data. 
Table ${ }^{222} \mathrm{Rn}$ activities and dissolved $\mathrm{CH}_{4}$ concentrations measured in groundwater and incubated soils. Evidence of the 2015 wildfire is noted for each sample. Depth is below the soil surface. Cond. $=$ conductivity. $\delta^{13} \mathrm{C}$ of dissolved $\mathrm{CH}_{4}$ are presented relative to Pee Dee Belemnite (PDB). $\mathrm{H}_{2} \mathrm{O}$ stable isotopes reported relative to Vienna Standard Mean Ocean Water (VSMOW). Average value \pm standard error is reported.

\begin{tabular}{|c|c|c|c|c|c|c|c|c|c|c|c|c|c|}
\hline Station & Type & Fire $^{a}$ & Lat. & Lon. & $\begin{array}{l}\text { Depth } \\
\mathrm{cm}\end{array}$ & $\begin{array}{c}\text { Cond } \\
\mathrm{mS} \\
\mathrm{cm}^{-1}\end{array}$ & $\begin{array}{l}\mathrm{O}_{2} \\
m g \\
L^{-1}\end{array}$ & $\begin{array}{c}\text { Temp } \\
{ }^{\circ} \mathrm{C}\end{array}$ & $\begin{array}{c}{ }^{222} \mathrm{Rn} \\
d p m \\
m^{-3}\end{array}$ & $\begin{array}{c}\mathrm{CH}_{4} \\
\mu \mathrm{mol}^{-1} \\
L^{-1}\end{array}$ & $\begin{array}{c}\delta^{13} \mathrm{C}_{\mathrm{CH} 4} \\
\% 。\end{array}$ & $\begin{array}{l}\delta^{2} \mathrm{H} \\
\% \circ\end{array}$ & $\begin{array}{c}\delta^{18} \mathrm{O} \\
\% \circ\end{array}$ \\
\hline WP5 & $\mathrm{GW}^{\mathrm{b}}$ & $\mathrm{N}$ & 61.263 & -163.245 & 30 & $\mathrm{ND}^{\mathrm{c}}$ & ND & ND & 48000 & ND & ND & ND & ND \\
\hline WP29 & GW & $\mathrm{Y} / \mathrm{N}$ & 61.270 & -163.237 & 30 & 0.085 & 2.8 & 5.1 & 15000 & 550.8 & -73.6 & -94.8 & -13.2 \\
\hline WT7-3 & $\mathrm{GW}$ & $\mathrm{Y} / \mathrm{N}$ & 61.270 & -163.237 & 30 & 0.030 & 3.3 & 3.7 & 35000 & 7.8 & -50.5 & -90.9 & -13.1 \\
\hline WP43 & $\mathrm{GW}$ & $Y$ & 61.267 & -163.247 & 30 & 0.186 & 5.1 & 16.8 & 36000 & 563.2 & -58.0 & -95.7 & -13.2 \\
\hline WP45 & GW & Y & 61.265 & -163.238 & 40 & 0.215 & 5.7 & 10.4 & 29000 & 612.2 & -65.2 & -106 & -14.6 \\
\hline WP30 & GW & $\mathrm{N}$ & 61.270 & -163.239 & 25 & 0.118 & 3.2 & 10.8 & ND & 456.2 & -50.0 & -94.0 & -14.0 \\
\hline WT8-2 & GW & Y & 61.270 & -163.236 & 30 & 0.043 & 0.9 & 12.6 & ND & 25.1 & -73.9 & -92.1 & -12.9 \\
\hline Bottom & $\operatorname{lnc} c^{d}$ & $\mathrm{Y} / \mathrm{N}$ & 61.264 & -163.246 & $0-5$ & ND & ND & ND & 38000 & ND & ND & ND & ND \\
\hline B2-T1 & Inc & Y & 61.321 & -163.243 & $0-30$ & ND & ND & ND & 5000 & ND & ND & ND & ND \\
\hline U1-T3 & Inc & $\mathrm{N}$ & 61.258 & -163.247 & $0-30$ & ND & ND & ND & 2000 & ND & ND & ND & ND \\
\hline U3-T1 & Inc & $\mathrm{N}$ & 61.270 & -163.237 & $0-30$ & ND & ND & ND & 1000 & ND & ND & ND & ND \\
\hline B3-T2 & Inc & Y & 61.271 & $\begin{array}{c}-163 . \\
235\end{array}$ & $0-30$ & ND & ND & ND & 32000 & ND & ND & ND & ND \\
\hline Avg. & & & & & & 0.113 & 3.5 & 9.9 & 24000 & 370 & -61.9 & -95.6 & -13.5 \\
\hline \pm & & & & & & 0.031 & 0.7 & 2.0 & 5000 & 110 & 4.4 & 2.2 & 0.3 \\
\hline
\end{tabular}

${ }^{\mathrm{a}} \mathrm{Y} / \mathrm{N}=$ yes or no for samples collected within the 2015 fire. ${ }^{\mathrm{b}} \mathrm{GW}=$ groundwater. ${ }^{\mathrm{c}} \mathrm{ND}=$ no data. ${ }^{\mathrm{d}}$ Inc $=$ Incubated soil or sediment. See ref. (Ludwig, Holmes, Natali, Mann, Schade, Jardine, et al., 2017) for more details on soil samples B2, U1, U3 and B3. 
Table 3 Measured soil and sediment characteristics used in the incubation experiments. Visible evidence of the 2015 wildfire is noted for each sample. Sediments were collected from the top $5 \mathrm{~cm}$. Soils were collected from the $0-30 \mathrm{~cm}$. Sample names started with B represent burned soils; U, unburned.

\begin{tabular}{cccccc}
\hline Sample name & Type & Fire in 2015? & Porosity & $\begin{array}{c}\text { Dry bulk density } \\
\mathrm{g} \mathrm{cm}^{-3}\end{array}$ & $\begin{array}{c}\mathrm{GW} \text { 222 } \mathrm{Rn} \\
\mathrm{dpm} \mathrm{m} \mathrm{m}^{-3}\end{array}$ \\
\hline Bottom Sediment & $\begin{array}{c}\text { Landing Lake } \\
\text { Sediment }\end{array}$ & $\mathrm{Y} / \mathrm{N}$ & 0.82 & 0.45 & 38000 \\
B2-T1 & Soil & $\mathrm{Y}$ & 0.86 & 0.19 & 4800 \\
U1-T3 & Soil & $\mathrm{N}$ & 0.93 & 0.09 & 1600 \\
U3-T1 & Soil & $\mathrm{N}$ & 0.90 & 0.13 & 1000 \\
B3-T2 & Soil & $\mathrm{Y}$ & 0.74 & 0.37 & 32000 \\
\hline
\end{tabular}


Table 4 Groundwater samples collected in 2017 (including those near Landing Lake and other lakes) and the associated ${ }^{222} \mathrm{Rn}$ activities and methane concentrations. Evidence of fire in 2015 is indicated by $\mathrm{Y} / \mathrm{N}$.

\begin{tabular}{|c|c|c|c|c|c|c|c|}
\hline Sample name & Type & Fire in $2015 ?$ & Lat. & Lon. & $\begin{array}{c}\text { Depth } \\
\mathrm{cm}\end{array}$ & $\begin{array}{c}{ }^{222} \mathrm{Rn} \\
d p m m^{-3}\end{array}$ & $\begin{array}{c}\mathrm{CH}_{4} \\
\mu \mathrm{mol}^{-1}\end{array}$ \\
\hline WP43 & $\mathrm{GW}^{1}$ & $Y$ & 61.267 & -163.247 & 30 & 36000 & 563.2 \\
\hline WP45 & GW & $Y$ & 61.265 & -163.238 & 40 & 29000 & 612.2 \\
\hline WT8-2 & GW & $Y$ & 61.270 & -163.236 & 22 & $N^{2}$ & 25.1 \\
\hline B1-WP27 & GW & $Y$ & 61.284 & -163.247 & 36 & 18000 & 520 \\
\hline B2-WP28 & GW & $Y$ & 61.273 & -163.230 & 55.5 & 36000 & 418.6 \\
\hline B3-WP37 & GW & $Y$ & 61.284 & -163.259 & 37 & 19000 & ND \\
\hline B4-WP39 & GW & $Y$ & 61.284 & -163.259 & 52 & 32000 & 628.6 \\
\hline B5-WP40 & GW & $Y$ & 61.288 & -163.262 & 52 & 26000 & 2.9 \\
\hline B2-T1 & $\ln c^{3}$ & $Y$ & 61.321 & -163.243 & $0-30$ & 4800 & ND \\
\hline B3-T2 & Inc & $Y$ & 61.271 & -163.235 & $0-30$ & 32000 & ND \\
\hline WP5 & GW & $\mathrm{N}$ & 61.263 & -163.245 & 30 & 48000 & ND \\
\hline UB1-WP10 & GW & $\mathrm{N}$ & 61.258 & -163.246 & 45 & 30000 & 635.3 \\
\hline UB1-WP15 & GW & $\mathrm{N}$ & 61.258 & -163.246 & 36 & 25000 & 517.3 \\
\hline UB2-WP25 & GW & $\mathrm{N}$ & 61.321 & -163.238 & 35 & 65000 & 98.4 \\
\hline WP30 & GW & N & 61.270 & -163.239 & 25 & ND & 456.2 \\
\hline U1-T3 & Inc & $\mathrm{N}$ & 61.258 & -163.247 & $0-30$ & 1600 & ND \\
\hline U3-T1 & Inc & $\mathrm{N}$ & 61.270 & -163.237 & $0-30$ & 1000 & ND \\
\hline Fire, average & & & & & & 26000 & 395.8 \\
\hline$\sigma^{2}$ & & & & & & $1.07 \times 10^{8}$ & $7.3 \times 10^{4}$ \\
\hline No fire, average & & & & & & 28000 & 426.8 \\
\hline$\sigma^{2}$ & & & & & & $6.39 \times 10^{8}$ & $5.4 \times 10^{4}$ \\
\hline
\end{tabular}

${ }^{1} \overline{\mathrm{GW}}=$ groundwater. ${ }^{2} \mathrm{ND}=$ no data. ${ }^{3}$ Inc $=$ incubation (See section 2.3.1) for description of incubation methods. 
Table 5 Estimates of groundwater fluxes, residence times, and methane fluxes for Landing Lake compared to other studies. Average and high activity endmembers refer to the concentrations of radon in groundwater.

\begin{tabular}{|c|c|c|c|c|c|c|}
\hline Lake name & $\begin{array}{l}\text { GWa flux } \\
\mathrm{cm} \mathrm{d-1}\end{array}$ & $\begin{array}{l}\text { Residence } \\
\text { time } \\
\text { days }\end{array}$ & $\begin{array}{c}\mathrm{GW}\left[\mathrm{CH}_{4}\right]^{\mathrm{b}} \\
\mu \mathrm{mol} \mathrm{L}^{-1}\end{array}$ & $\begin{array}{l}\mathrm{GW} \mathrm{CH} \mathrm{CH}_{4} \text { flux } \\
m m o l m^{-2} d^{-1}\end{array}$ & $\begin{array}{l}\text { Lake }\left[\mathrm{CH}_{4}\right] \\
\qquad \mu \mathrm{mol} \mathrm{L}^{-1}\end{array}$ & $\begin{array}{c}\text { Air-water } \mathrm{CH}_{4} \\
\text { flux } \\
\text { mmol } m^{-2} d^{-1}\end{array}$ \\
\hline $\begin{array}{l}\text { Landing Lake } \\
\text { average } \\
\text { endmember }\end{array}$ & $\begin{array}{c}1.2 \pm 0.6 \\
\text { to } 4.3 \pm \\
2.0\end{array}$ & $12-44$ & $370(8-612)$ & $4 \pm 2$ to $16 \pm 7$ & $1.8 \pm 0.3$ & $\begin{array}{l}1.3-2.3 \\
(1.3-5.7)\end{array}$ \\
\hline $\begin{array}{l}\text { Landing Lake } \\
\text { high activity } \\
\text { endmember }\end{array}$ & $\begin{array}{c}0.6 \pm 0.3 \\
\text { to } 2.1 \pm \\
0.9\end{array}$ & $25-88$ & $370(8-612)$ & $2 \pm 1$ to $8 \pm 3$ & $1.8 \pm 0.3$ & $\begin{array}{l}1.3-2.3 \\
(1.3-5.7)\end{array}$ \\
\hline $\begin{array}{c}\text { Toolik Lake } \\
\text { (Garcia-Tigreros } \\
\text { Kodovska et al., } \\
\text { 2016; Paytan et al., } \\
\text { 2015) }\end{array}$ & $1.4 \pm 0.9$ & $N^{d}$ & $\begin{array}{c}8-35 \\
(0.01-150)\end{array}$ & $0.1-0.7$ & $0.02-0.8$ & $0.06-0.2$ \\
\hline $\begin{array}{l}\text { Northern peatland } \\
\text { ponds }(n=38) \\
\text { (Wik et al., 2016) }\end{array}$ & ND & ND & ND & ND & ND & $\begin{array}{c}7 \\
(2-10)\end{array}$ \\
\hline
\end{tabular}

${ }^{\mathrm{a}} \mathrm{GW}=$ groundwater. ${ }^{\mathrm{b}}$ Average listed along with minimum and maximum in parentheses. Other values listed with entire range of estimates or as average \pm standard deviation. ${ }^{c}$ Estimated air-water fluxes calculated using Equation 1 and measured air-water fluxes via 24 -hr measurement period flux chambers in 2018 listed in parentheses. See Table 6 in Appendix for details. ${ }^{\mathrm{d}} \mathrm{ND}=$ no data. 
Table 6 The methane concentrations, measured fluxes, and measured gas exchange coefficients for Landing Lake, July 2018. Each method is described in Section 2.2. Average wind speed over the 3 days was $4.6 \pm 1.1 \mathrm{~m} \mathrm{~s}^{-1}$. All measurements were made at the same location (latitude, longitude): 61.26583, -163.24199.

\begin{tabular}{|c|c|c|c|c|c|c|}
\hline Sample & Method & $\begin{array}{c}\text { Length of } \\
\text { deployment }\end{array}$ & $\begin{array}{l}\text { Temp. } \\
\text { of }\end{array}$ & $\begin{array}{c}\text { Lake } \\
\mathrm{CH}_{4} \\
\mu \mathrm{mol} \mathrm{L}^{-1}\end{array}$ & $\begin{array}{c}\mathrm{CH}_{4} \text { flux } \\
\underset{1}{m m o l ~} m^{-2} d^{-}\end{array}$ & $\begin{array}{l}\mathrm{k}_{600} \\
m d^{-1}\end{array}$ \\
\hline 7_8 & 24-hr period & $3.6 \mathrm{hr}$ & 13.3 & 2.35 & 5.7 & 0.24 \\
\hline 7_8 & Instantaneous & $15 \mathrm{~min}$ & 13.3 & 2.35 & 21.8 & 0.93 \\
\hline 7_9 & 24-hr period & $28.7 \mathrm{hr}$ & 12.1 & 0.93 & 2.0 & 0.23 \\
\hline 7_9 & Instantaneous & $15 \mathrm{~min}$ & 12.1 & 0.93 & 6.3 & 0.71 \\
\hline 7_10A & 24-hr period & $16.6 \mathrm{hr}$ & 11.6 & 0.65 & 1.8 & 0.29 \\
\hline 7_10A & Instantaneous & $15 \mathrm{~min}$ & 11.6 & 0.65 & 17.1 & 2.32 \\
\hline 7_10B & 24-hr period & $21.4 \mathrm{hr}$ & 12.7 & 0.58 & 1.3 & 0.24 \\
\hline 7_10B & Instantaneous & $15 \mathrm{~min}$ & 12.7 & 0.58 & 17.0 & $N D^{a}$ \\
\hline 7_10C & Instantaneous & $15 \mathrm{~min}$ & 13.7 & ND & 5.1 & ND \\
\hline \multicolumn{3}{|c|}{ 24-hr measurement period average } & 12.4 & 1.1 & 2.7 & 0.251 \\
\hline \multicolumn{3}{|l|}{ \pm} & 0.7 & 0.8 & 1.0 & 0.014 \\
\hline \multicolumn{3}{|c|}{ Instantaneous average } & 12.7 & 1.1 & 13.5 & 1.32 \\
\hline \multicolumn{3}{|l|}{ \pm} & 0.9 & 0.8 & 7.4 & 0.50 \\
\hline
\end{tabular}

${ }^{\mathrm{a}} \mathrm{ND}=$ no data. 
Table 7 The parameters in the mass balance and the methods for estimating the uncertainty in each parameter.

\begin{tabular}{|c|c|}
\hline Parameter & Estimation of uncertainty \\
\hline Gas exchange, Wind Speed Model & $\begin{array}{l}\text { Slope error }(19 \%) \text {; standard deviation of measured wind speeds }(<1 \%, \mathrm{n} \\
>1000)\end{array}$ \\
\hline Gas exchange, Size Class Model & Estimated at $20 \%$ (std error $=7-25 \%$ in Holgerson \& Raymond, 2016 ) \\
\hline $\begin{array}{l}\text { Gas exchange, direct } \\
\text { measurement }\end{array}$ & Standard error of measurements (24-37\%) \\
\hline Gas exchange in mass balance & $\begin{array}{l}\text { Two estimates: Conservative = Size Class, Upper Limit }=\text { Wind Speed; } \\
\text { Both errors } \sim 20 \%\end{array}$ \\
\hline Decay & Standard error of lake ${ }^{222} \mathrm{Rn}$ inventories $(11 \%, \mathrm{n}=18)$ \\
\hline Recharge & Impact on mass balance discussed in Section 4.1 .1 \\
\hline Stream discharge (out of lake) & Impact on mass balance discussed in Section 4.1 .1 \\
\hline Diffusion from bottom sediments & Propagated measurement error of the two methods (19\%) \\
\hline Dissolved ${ }^{226} \mathrm{Ra}$ & Measurement error of ${ }^{226} \mathrm{Ra}$ by gamma spectrometry ( $\left.8 \%\right)$ \\
\hline Groundwater ${ }^{222} \mathrm{Rn}$ flux & Propagated uncertainty of all model terms (41\%) \\
\hline Groundwater flux $\left(\mathrm{cm} \mathrm{d}^{-1}\right)$ & $\begin{array}{l}\text { Reported range for each estimate propagated from: } 1) \text { uncertainty of } \\
\left.\text { the }{ }^{222} \mathrm{Rn} \text { flux }(41 \%) ; 2\right) \text { standard error in average groundwater } \\
\text { endmember }(21 \%, \mathrm{n}=10) \text { OR measurement error in high activity } \\
\text { groundwater endmember }(8 \%)\end{array}$ \\
\hline
\end{tabular}




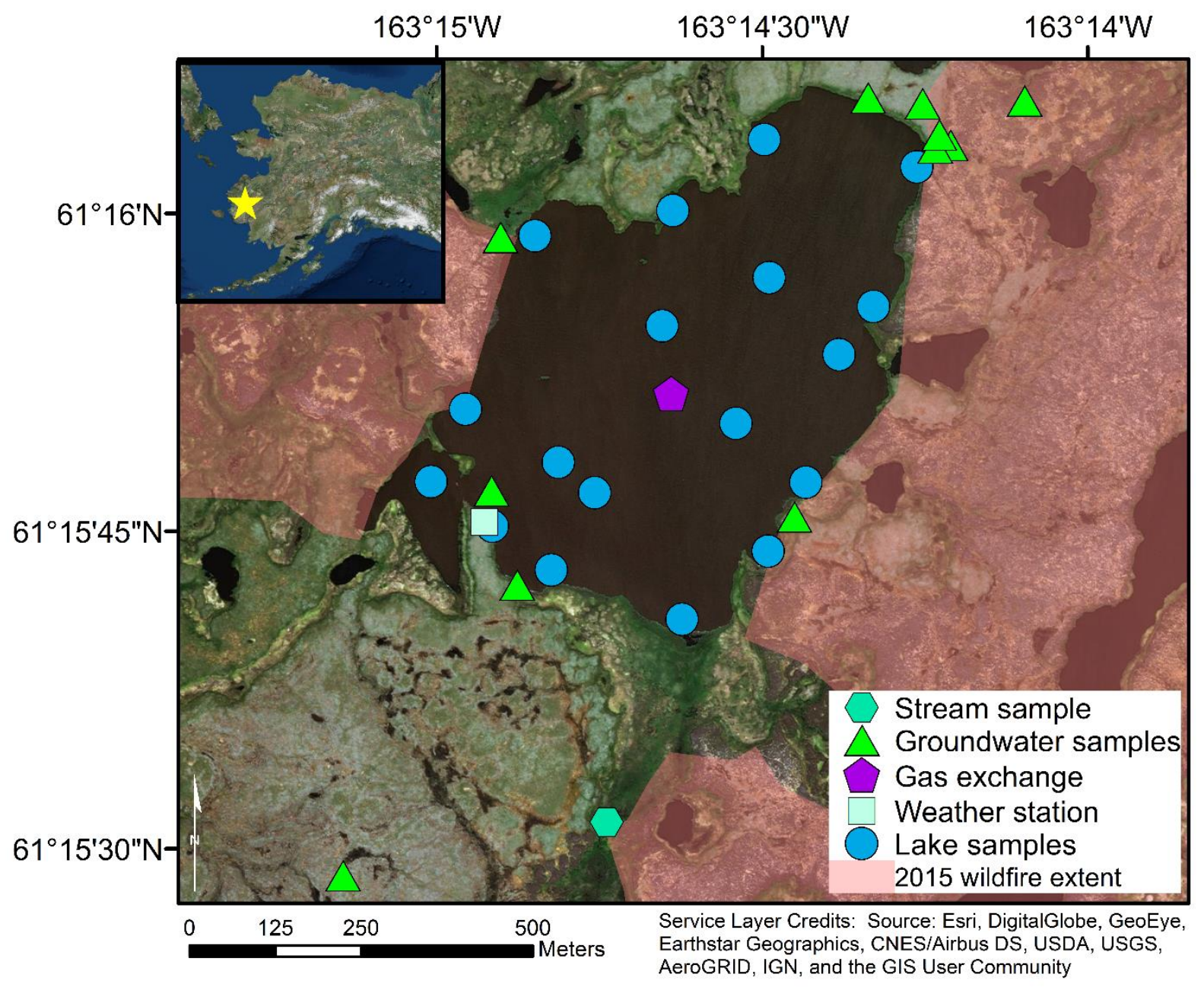

Figure 1 "Landing Lake" sampling locations and the study site location within Alaska, USA shown in inset (star symbol). One groundwater sample (B2) is not shown because it was $5 \mathrm{~km}$ north of Landing Lake (Figure was made using ArcMap 10.5.1). 

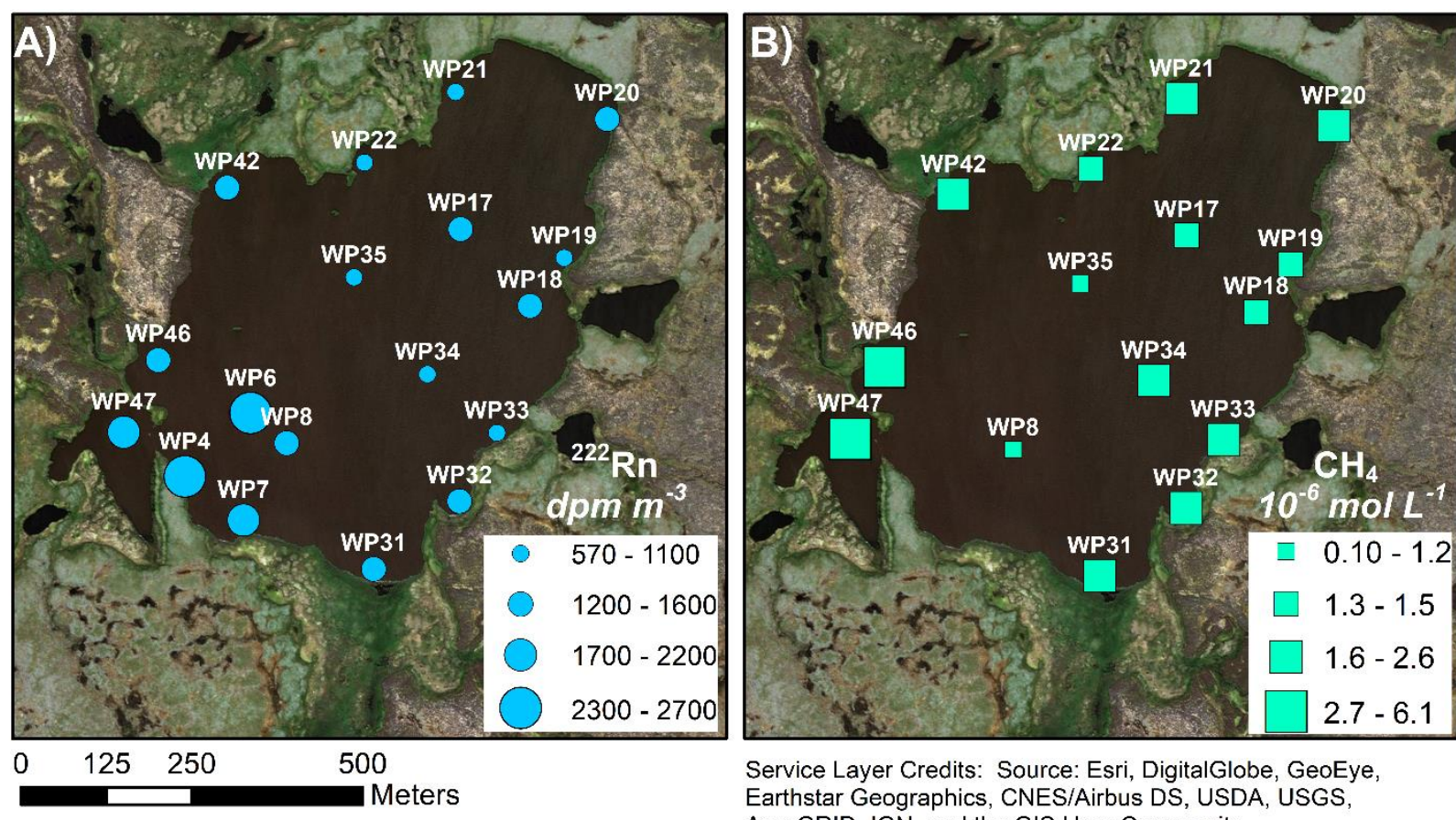

Service Layer Credits: Source: Esri, DigitalGlobe, GeoEye, Earthstar Geographics, CNES/Airbus DS, USDA, USGS, AeroGRID, IGN, and the GIS User Community

Figure 2 Concentrations of (a) dissolved ${ }^{222} \mathrm{Rn}$ and (b) dissolved methane in Landing Lake. Sizes of symbols represent relative concentrations. $\mathrm{CH}_{4}$ error $=30 \%$ for all samples; ${ }^{222} \mathrm{Rn}$ error $=16 \%$ for WP4, 0.1-6\% for all other samples. (Figure was made using ArcMap 10.5.1). 


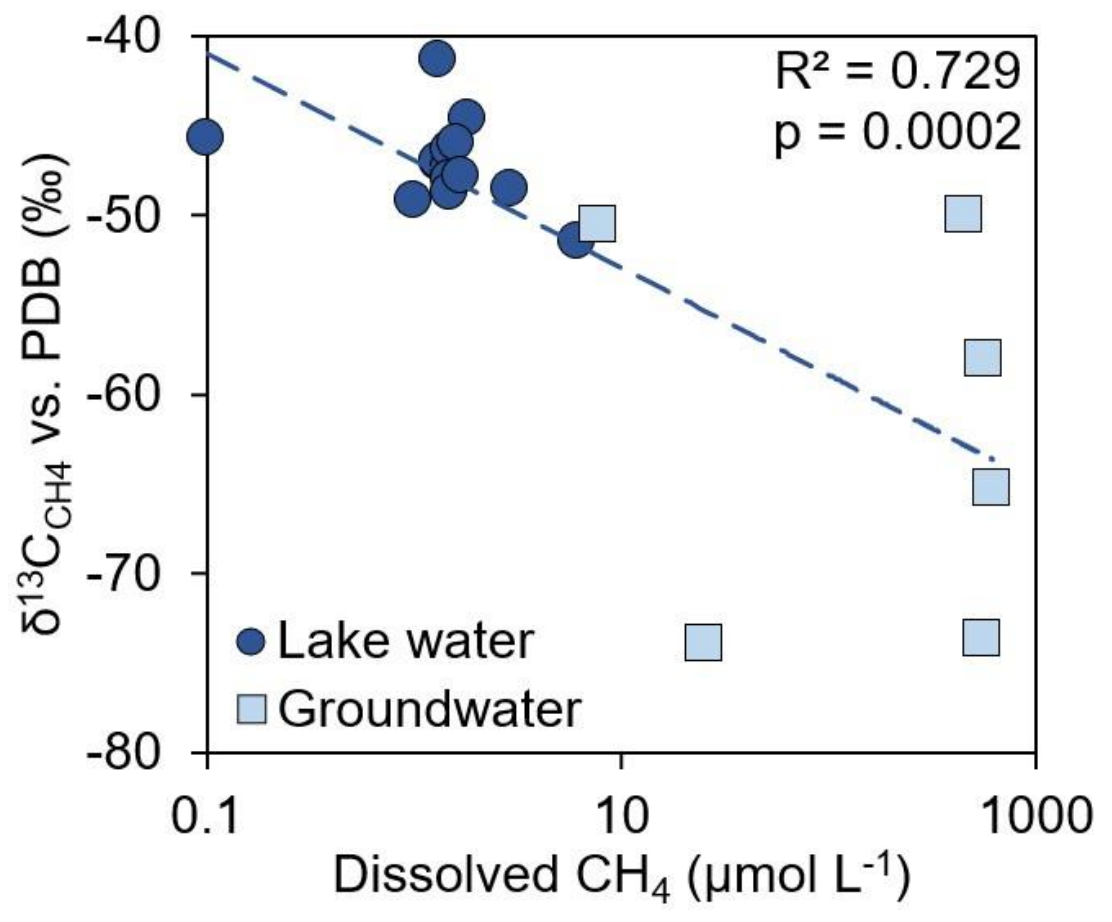

Figure 3 Stable carbon isotopes of dissolved $\mathrm{CH}_{4}$ as a function of $\mathrm{CH}_{4}$ concentration in groundwater (light blue squares) and surface water samples (dark blue circles) at Landing Lake in 2017. Notice the logarithmic scale on the $\mathrm{x}$-axis. The regression equation is $\delta^{13} \mathrm{C}=-5.98 \log$ $\left[\mathrm{CH}_{4}, \mu \mathrm{mol} \mathrm{L} \mathrm{L}^{-1}\right]-46.9 \%$ and includes both the lake waters and groundwaters. PDB $=$ Pee Dee Belemnite standard. (Figure made using Microsoft Excel). 


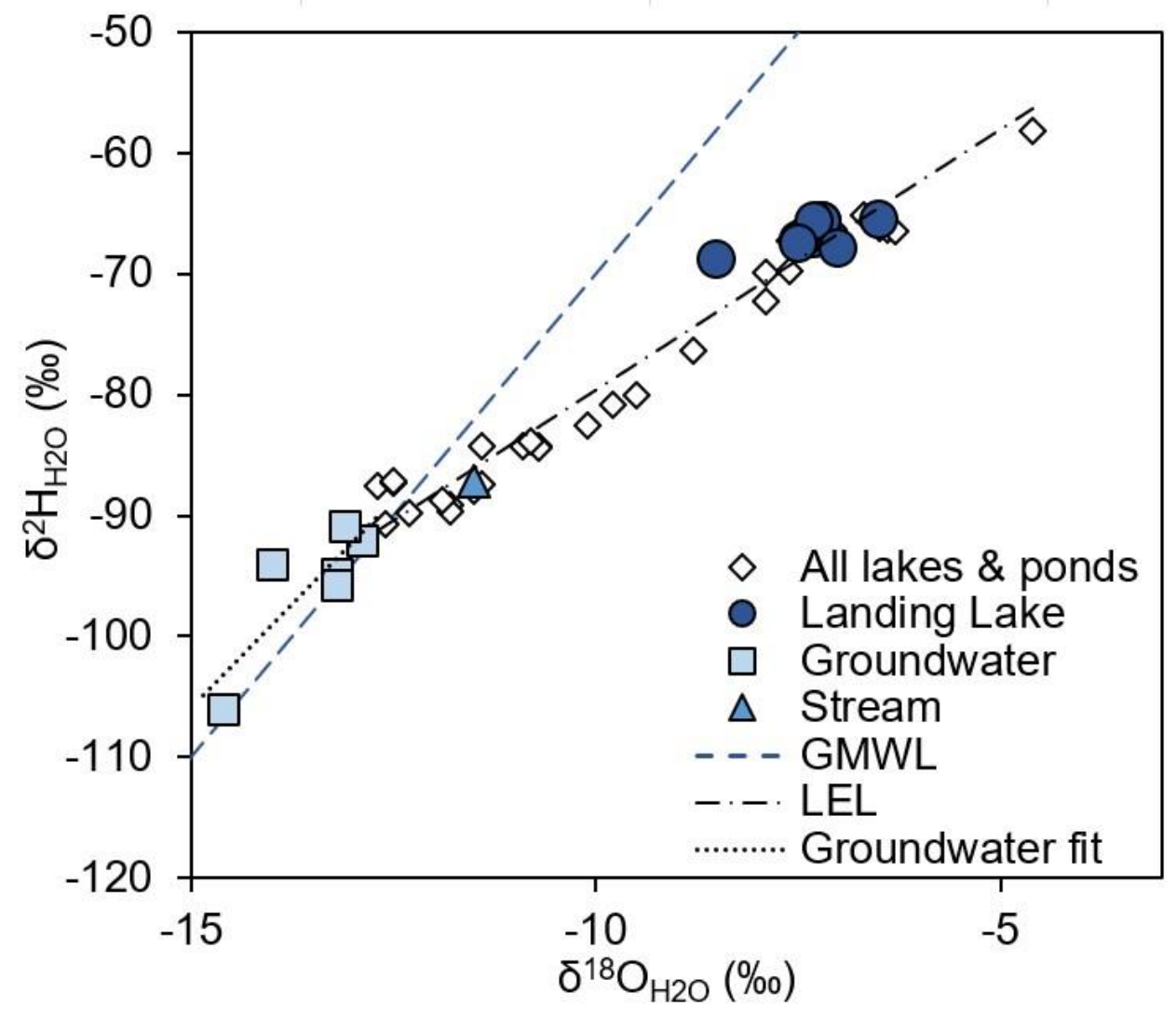

Figure 4 The stable isotope values for $\delta^{2} \mathrm{H}$ and $\delta^{18} \mathrm{O}$ in water for samples collected in 2017. The stream sample (triangle) drains Landing Lake. The dashed line is the Global Meteoric Water Line (Craig, 1961). Diamonds represent all lake and pond samples collected in 2017 (see data online: (Ludwig, Holmes, Natali, Mann, Schade, Jimmie, et al., 2017)) which were fit with a Local Evaporation Line (LEL): $\delta^{2} \mathrm{H}_{\mathrm{H} 2 \mathrm{O}}=4.31\left(\delta^{18} \mathrm{O}\right)-36.55 \%$ o $\left(\mathrm{R}^{2}=0.96, \mathrm{p}<<0.01\right)$. The dotted black line is the best-fit line for Landing Lake groundwaters: $\delta^{2} \mathrm{H}_{\mathrm{H} 2 \mathrm{O}}=6.87\left(\delta^{18} \mathrm{O}\right)-$ $2.90 \%\left(\mathrm{R}^{2}=0.70, \mathrm{p}=0.04\right)$. (Figure made using Microsoft Excel). 


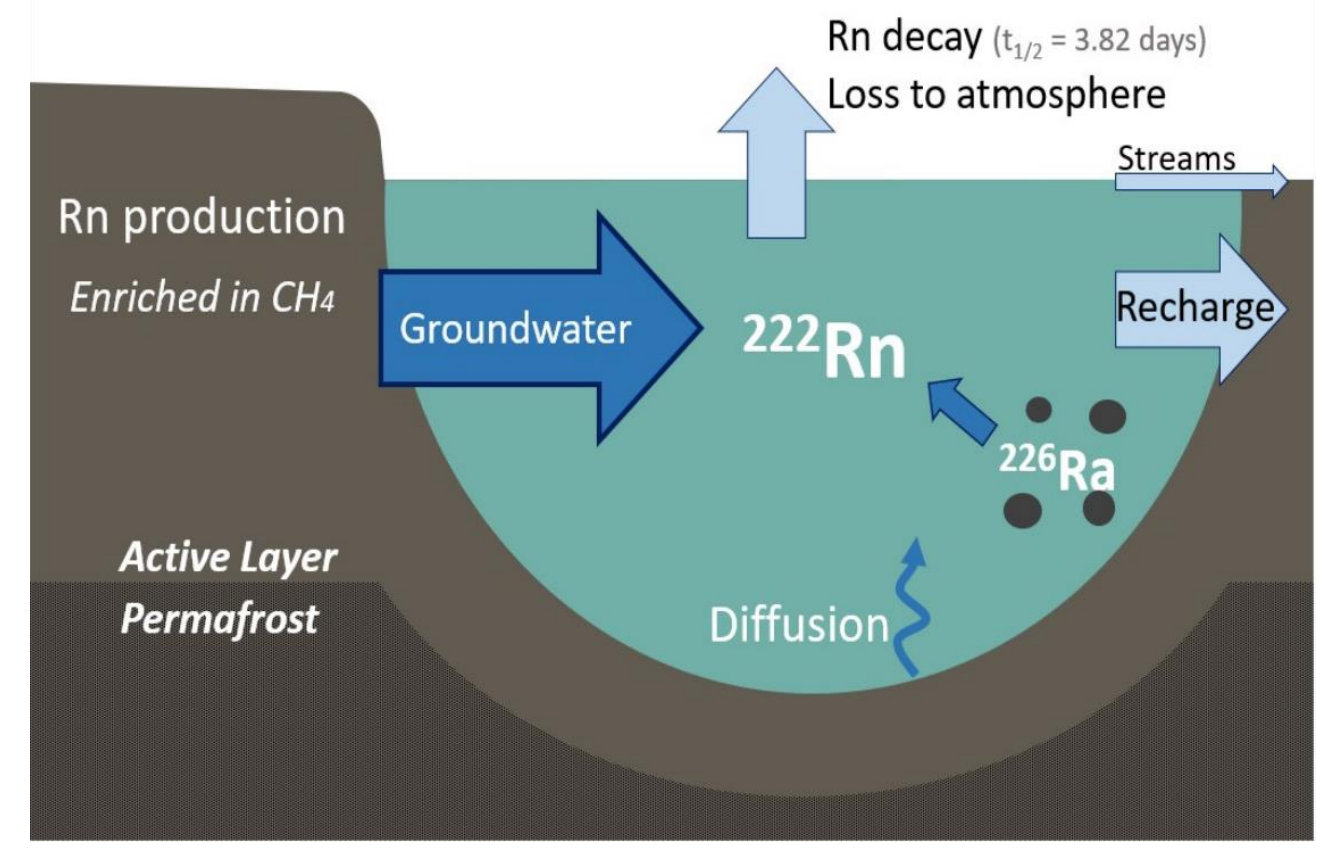

Figure 5 A conceptual model showing the sources and sinks of 222Rn in Landing Lake. Sources (dark blue arrows) include decay of dissolved 226Ra in lake water, diffusion from lake bottom sediments and groundwater. Sinks (light blue arrows) include 222Rn decay, loss to the atmosphere via gas exchange, recharge into soils, and the stream outlet. (Figure made using Microsoft Powerpoint). 


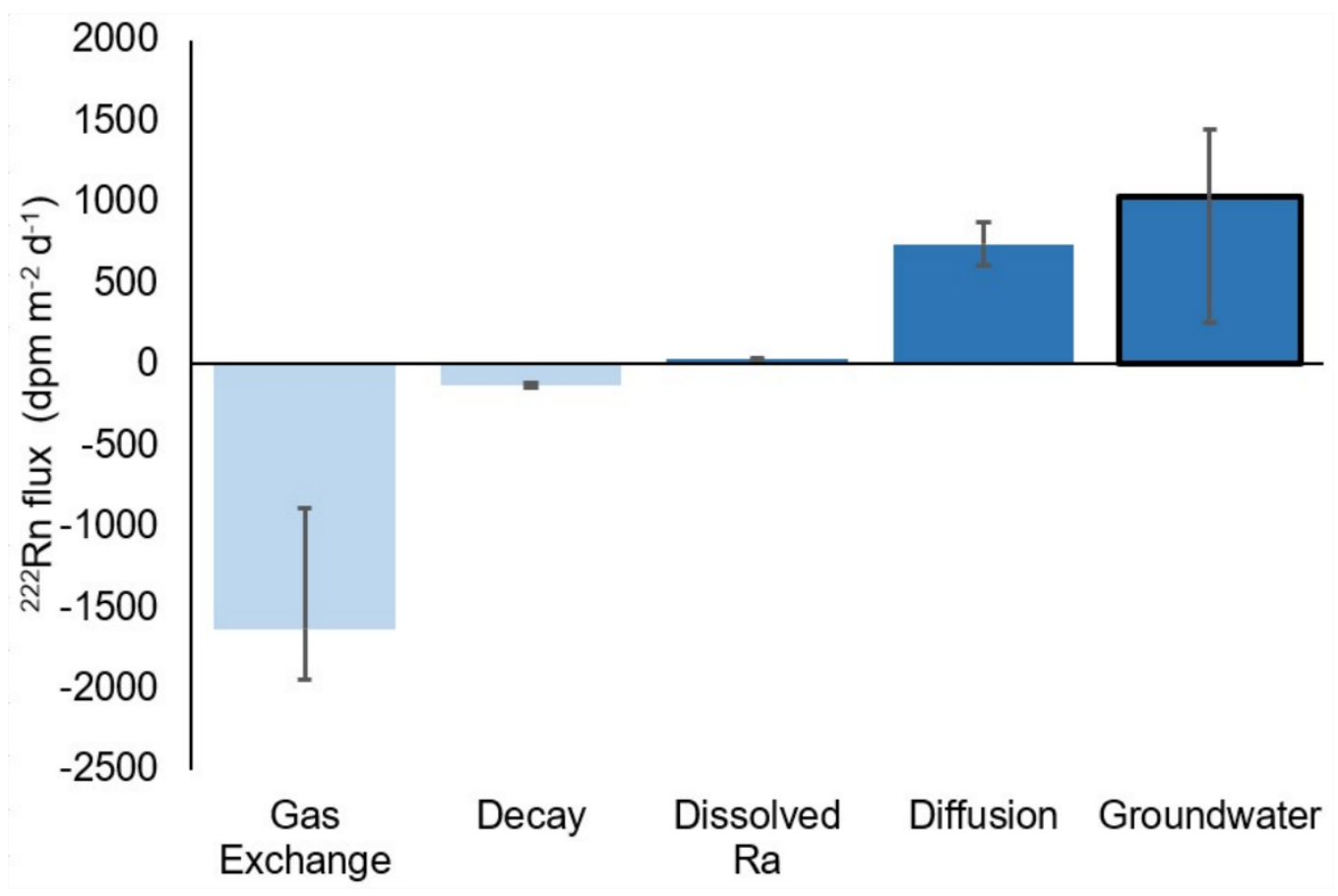

Figure 6 The fluxes of ${ }^{222} \mathrm{Rn}$ for each source (dark blue) and sink (light blue) in the mass balance model for Landing Lake. The radon flux due to groundwater is highlighted with a black outline because it is the difference between the sinks and the other two sources. Error bars are propagated errors. Lower limits are the conservative estimate discussed in the text. (Figure made using Microsoft Excel). 


\title{
Chapter 3: Autumn storms and winter water formation as drivers of sediment-water interaction on the Beaufort Sea Shelf
}

\begin{abstract}
Climate change is causing sea ice loss on Arctic continental shelves, resulting in increases of shelf-derived materials to the Arctic Ocean. Sediment-water interaction can chemically transform water as it moves across the shelf, enriching shelf waters in nutrients and carbon, which can impact primary productivity and greenhouse gas cycling. However, the drivers of sediment-water interaction in the Arctic Ocean are poorly understood. In this study, we use observations from cruise HLY1803 in late October-November, 2018 on the Beaufort shelf to investigate the impact of storms and winter water formation on sediment-water interaction. We observed three storm events with contrasting atmospheric conditions, and therefore different upwelling responses on the shelf. Observations of polynyas on the shelf coincided with locations of newly ventilated winter water. In response to winter water formation, differences between surface and bottom water radium activities decreased, indicating a decrease in stratification. Radium-228 in shelf bottom waters increased from $9.5 \pm 0.9$ to $10.7 \pm 0.8 \mathrm{dpm} 100 \mathrm{~L}^{-1}$. The ${ }^{228} \mathrm{Ra} /{ }^{226} \mathrm{Ra}$ activity ratio increased from $0.79 \pm 0.04$ to $0.82 \pm 0.07$, with a maximum value of 0.91 . Short-lived radium isotopes were used to calculate the water mass time since sedimentwater interaction, and decreased in the first week from 2.3-5.4 days to 0.9-4.1 days, then increased to 5.0 to 7.9 days during the second week, with the exception of one very young sample at $\sim 60 \mathrm{~km}$ from shore that had an age of $\sim 0.1$ days. $\mathrm{NH}_{4}{ }^{+}$concentrations increased from $0-0.5 \mu \mathrm{M}$ to $2-4 \mu \mathrm{M}$ during this time period. Our results suggest that processes related to ice formation have the ability to drive dissolved constituents from sediment porewaters into the water column. The spatial variability in chemical constituents and radium age data also suggest that these sediment-water interaction events are episodic in nature, and that mesoscale water column features can drive local exchange with the benthos.
\end{abstract}




\subsection{Introduction}

The Arctic Ocean is strongly influenced by continental shelves, which make up 50\% of its area (Jakobsson, 2002). Climate warming is causing sea ice loss over shelves, allowing for increased vertical mixing and shelf-basin exchange (Carmack \& Chapman, 2003a; Rainville et al., 2011; Williams \& Carmack, 2015). In the past two decades, increases in shelf-derived materials have been observed in the central Arctic (Kipp et al., 2018; Rutgers van der Loeff et al., 2018). These material inputs are in part due to sediment-water interactions (SWIs), which chemically transform water as it moves across the shelf, transferring nutrients, carbon, and trace metals from sediments into the water column (Z. W. Brown et al., 2015; Shen et al., 2016; Vieira et al., 2019). Because these inputs can influence biological productivity and greenhouse gas cycling, it is important to understand the drivers of SWI on Arctic continental shelves.

During late autumn through early spring, shelf water is transformed physically and chemically via ice formation that rejects brine and causes vertical convection, creating an Arctic water mass known as Newly Ventilated Winter Water (WW, e.g. Pacini et al., 2019). This cold water, near the freezing point, is rich in nutrients and trace metals due to interaction with the sediments (Granger et al., 2018; Jones \& Anderson, 1986; Vieira et al., 2019). Winter water is known to form within large, semi-permanent polynyas (Gong \& Pickart, 2015; Itoh et al., 2012; Weingartner et al., 1998) and in small leads and polynyas throughout the Chukchi Sea (Pacini et al., 2019), which ultimately exits the shelf and ventilates the upper halocline of the Arctic Ocean (Aagaard et al., 1981). However, little is known about WW formation in late autumn and its effect on sediment-water interaction (SWI), in part due to the lack of shipboard measurements that time of year.

The nutrients released from bottom sediments as a result of WW formation, such as dissolved inorganic nitrogen and trace metals, are involved in numerous biogeochemical cycling processes (Bruland \& Lohan, 2003; Cid et al., 2012; Cota et al., 1996; Lee et al., 2010; Tremblay et al., 2006), making it difficult to use them as tracers of SWI and WW formation processes. However, naturally occurring radium isotopes $\left({ }^{223} \mathrm{Ra}, \mathrm{t}_{1 / 2}=11.4 \mathrm{~d} ;{ }^{224} \mathrm{Ra}, \mathrm{t}_{1 / 2}=3.66 \mathrm{~d} ;{ }^{226} \mathrm{Ra}, \mathrm{t}_{1 / 2}\right.$ $=1600 \mathrm{y} ;{ }^{228} \mathrm{Ra}, \mathrm{t}_{1 / 2}=5.75 \mathrm{y}$ ), are similarly sourced and behave conservatively on the time scales of shelf circulation. They are produced through the decay of sediment-bound thorium isotopes, and because of their higher solubility, dissolve into bottom sediment porewaters, which then can be released through diffusive or convective processes (Charette et al., 2008; Webster et al., 1995). Radium isotopes can also enter the coastal ocean through river runoff or submarine groundwater discharge (Moore, 2010; Mulligan \& Charette, 2006; Rutgers van der Loeff et al., 2003). Radium then is lost to decay based on its half-life and dilution through mixing with open ocean waters (Charette et al., 2008). ${ }^{228} \mathrm{Ra}$ has been well studied as a tracer of shelf waters influenced by sediments in the Arctic (Charette et al., 2020; Kipp et al., 2020; Rutgers van der Loeff et al., 1995, 2012, 2018), but comparatively little work has employed the use of the shortlived radium isotopes to observe SWI on shorter timescales of days to weeks. 
Here, we combine physical and chemical observations from an autumn field program in late October to mid November 2018 to elucidate the influence of wind-driven and ice-formationdriven vertical convection and SWI on the Beaufort shelf. We first describe the atmospheric and sea ice conditions during the cruise, followed by an analysis of the hydrographic data as they relate to the water column response to storms and ice formation. We then present water column measurements of radium isotopes and ammonium, a common form of inorganic nitrogen in marine sediments, along with sedimentary measurements of radium isotopes to inform the water column observations. Finally, we discuss a timeseries of storm events and WW formation during three periods in early November across the Beaufort shelf, and use chemical evidence to investigate the extent of SWI as WW forms and spreads.

\subsection{Study Area}

The Chukchi and Beaufort continental shelves of the Arctic are characterized as inflow shelves due to inflow of Pacific Water through Bering Strait (W. J. Williams \& Carmack, 2015). This water is transported across the Chukchi shelf, and some of it turns to the east after exiting Barrow canyon to form the Beaufort Shelfbreak Jet (Figure 1a, Nikolopoulos et al., 2009; Pickart, 2004). This eastward flow can be temporarily reversed during wind-driven upwelling events (Pickart et al., 2009, 2011; Pickart, Spall, et al., 2013), or be strengthened during winddriven downwelling (Foukal et al., 2019). The upwelling is often associated with low pressure systems passing over the Aleutian Islands, which, in combination with the Beaufort High, a quasi-stationary high-pressure system over the Beaufort Sea (Walsh, 1978), cause strong easterly winds in the Beaufort Sea (e.g. Pickart et al., 2009). The upwelling at the shelfbreak is most common in autumn (Lin et al., 2019), with an increase in frequency in recent years (Pickart, Schulze, et al., 2013). When winds exceed 4-5 $\mathrm{m} \mathrm{s}^{-1}$ for at least 6-18 hours, the along-shelf flow reverses to the west, followed roughly 10 hours later by upwelling of water from the halocline. Outside of the summer months, the majority of the events bring warm, salty, nutrient-rich Atlantic Water onto the shelf (Lin et al., 2019). Downwelling occurs when cyclonic low-pressure systems replace the Beaufort High, leading to strong westerly winds over the region. This occurs most commonly in July and August (Foukal et al., 2019). This leads to an acceleration of the shelfbreak jet, followed roughly 10 hours later by downwelling of near-bottom water off the Beaufort shelf that ventilates the upper halocline of the Canada Basin (Foukal et al., 2019).

In this study, we collected samples during the autumn freeze-up in 2018 across the entire Alaskan Beaufort shelf between the eastern Chukchi Sea and the Mackenzie Canyon. The focus of the paper is on the set of samples from the central Beaufort shelf $\left(145-150^{\circ} \mathrm{W}\right.$; Figure $\left.2 \mathrm{~b}\right)$. We occupied multiple hydrographic sections in this region over two weeks in early November, and although they were not precisely co-located, we assume that they were similarly impacted by ice formation and changes in circulation due to storm activity. In terms of SWI, the mineral and organic carbon content of the sediments is relatively consistent from east to west in this portion of the Alaskan Beaufort Sea, with some inner to outer shelf gradients in terrestrial organic matter sources (Goñi et al., 2013; Naidu et al., 2000; Naidu \& Mowatt, 1983), so we assume that 
benthic sources of radium isotopes and nutrients do not vary strongly between transects. The paper is further divided into three sampling periods based on easterly wind events and progressive cooling of the water column with time due to sea ice and WW formation. Period 1 (Oct 30-Nov 1) is characterized by a short, easterly wind event at the early stages of WW formation on the inner shelf. In Period 2 (Nov 3-7), a strong, easterly wind event extends over several days associated with further ice formation. During Period 3 (Nov 10-14), a weaker easterly wind event occurs as average sea ice concentrations increase to nearly $100 \%$ on the shelf, while the presence of WW continues to increase.

\subsection{Methods}

\subsubsection{Sample collection and analysis}

Samples were collected from October 25 - November 19, 2018 aboard USCGC Healy cruise HLY1803. A total of 196 stations were occupied along 19 transects, a subset of which we present in Figure 2b. At all stations, hydrographic data were collected using a Sea-Bird 911+ conductivity-temperature-depth (CTD) system, configured to measure pressure, temperature, conductivity and beam transmission on a 24-position rosette with 12-L bottles. A laboratory calibration of the temperature and beam transmission sensors was done before and after the cruise, and an in-situ calibration of the conductivity sensors was carried out during the cruise via bottle salinity measurements. Accuracies were determined to be $0.001{ }^{\circ} \mathrm{C}$ for temperature and 0.002 for salinity (practical salinity scale). Vertical sections were constructed using a Laplacianspline interpolation scheme with a typical grid spacing of $5 \mathrm{~km}$ and $2 \mathrm{~m}$, in the horizontal and vertical, respectively. The variables considered are potential temperature referenced to the sea surface (hereafter referred to simply as temperature), salinity, and potential density referenced to the sea surface (hereafter referred to as density).

Velocity of the water column was measured using the ship's hull-mounted RDI Ocean Surveyor $150 \mathrm{kHz}$ acoustic Doppler current profiler (ADCP). Data coverage was typically from $18 \mathrm{~m}$ depth to approximately $10 \mathrm{~m}$ above the seafloor. Because of the presence of sea ice, most ADCP profiles were collected while on station. The data were processed following the procedure described in Pickart et al. (2016). Barotropic tidal signals were removed using the Oregon State University model (Padman \& Erofeeva, 2004). Absolute geostrophic velocity sections were made by referencing the thermal wind shear to the direct ADCP measurements following Pickart et al. (2016).

Samples $(\sim 250 \mathrm{~L})$ for radium isotopes were collected at 72 stations using Niskin bottles on the CTD rosette. At shelf stations, samples were collected 4-7 $\mathrm{m}$ above the seafloor in order to focus on the influence of SWI. On the slope, samples were collected in the same potential density range as the bottom water on the shelf to maximize the chance of sampling the same water masses on and off the shelf. Surface water samples were collected for comparison with bottom water samples. Samples were pre-filtered through $10 \mu \mathrm{m}$ and $1 \mu \mathrm{m}$ Hytrex cartridges and transferred to plastic barrels. The samples were then filtered at $\sim 1 \mathrm{~L} \mathrm{~min}^{-1}$ through $\mathrm{MnO}_{2}$-coated acrylic fibers to quantitatively capture radium (Moore \& Reid, 1973). Fibers were rinsed with 
radium-free deionized water and dried partially with filtered air prior to analysis for short-lived isotopes $\left({ }^{223} \mathrm{Ra},{ }^{224} \mathrm{Ra}\right)$ on the Radium Delayed Coincidence Counter (RaDeCC) system (Moore $\&$ Arnold, 1996). Initial analyses were performed on the ship within 3 days of collection; samples were further analyzed in the lab after 1 and 2 months to determine the ${ }^{224} \mathrm{Ra}$ and ${ }^{223} \mathrm{Ra}$ activities supported by ${ }^{228} \mathrm{Th}$ and ${ }^{227} \mathrm{Ac}$, respectively; therefore, all reported values of ${ }^{224} \mathrm{Ra}$ and ${ }^{223} \mathrm{Ra}$ are excess $\left({ }^{224} \mathrm{Ra}\right.$ ex and ${ }^{223} \mathrm{Ra}$ ex $)$ activities in the water column not supported by their parents.

For analysis of long-lived radium isotopes, fibers were ashed in a muffle furnace at $820^{\circ} \mathrm{C}$ for 24 hours. The ash was sealed in polystyrene vials with epoxy (to prevent ${ }^{222} \mathrm{Rn}$ loss), stored for at least 1 month to allow for daughter-product ingrowth, and counted on a high-purity, well-type germanium gamma detector to measure ${ }^{228} \mathrm{Ra}$ and ${ }^{226} \mathrm{Ra}$ using the spectral lines for ${ }^{228} \mathrm{Ac}(338$ and $911 \mathrm{keV})$ and ${ }^{214} \mathrm{~Pb}(352 \mathrm{keV})$, respectively. Detector efficiencies were determined using standards prepared in the same geometry as the samples. Analytical uncertainties for all radium isotopes are reported as $1 \sigma$.

At most of the hydrographic stations, nutrient samples were collected from Niskin bottles at $\sim 10 \mathrm{~m}$ intervals. These samples were not filtered due to relatively low particulate load during the cruise. Samples were frozen until analysis at the University of Alaska using a Seal Analytical continuous-flow QuAAtro39 AutoAnalyzer. Following each run, the data were manually inspected, any blank was subtracted and final concentrations were calculated based on a linear curve fit using Seal Analytical AACE 7.07 software. Reagent solutions and primary and secondary standards were prepared with fresh Milli-Q water and working standards were prepared daily with low nutrient artificial seawater and primary standards with $>99 \%$ purity from Fisher Scientific and/or VWR. A second set of nutrient samples was collected coincident with radium samples, after pre-filtering but prior to plastic barrel storage. These samples were similarly analyzed at the Woods Hole Oceanographic Institution Nutrient Analytical Facility using a four-channel segmented flow Seal AA3 HR Autoanalyzer. The detection limits for $\mathrm{NH}_{4}$ was $\sim 0.015 \mu \mathrm{M}$ for both sets of nutrient analyses.

Bulk surface sediments (upper 5-10 cm) were collected at 28 of the hydrographic stations using a van Veen Grab. Sediments were stored in clean plastic bags and kept frozen until analysis. Sediments were weighed, dried, then re-weighed to determine water content and porosity assuming a mineral grain density of $2.65 \mathrm{~g} \mathrm{~cm}^{-3}$ and corrected for sea salt. Aliquots of these sediment samples were analyzed for radium isotopes. Surface available ${ }^{223} \mathrm{Ra}$ and ${ }^{224} \mathrm{Ra}$ were measured using a modified procedure described by Cai et al. (2012). MilliQ water was added to dried, weighed sediments to form a slurry, followed by co-precipitation of any desorbed radium, thorium or actinium by $\mathrm{MnO}_{2}$ suspension. The precipitate and sediments were filtered onto a $142 \mathrm{~mm} 0.7 \mu \mathrm{m}$ GFF filter, and analyzed in a sample chamber in the same geometry as the standards. In addition to creating a ${ }^{228} \mathrm{Th}$ set of standards for ${ }^{224} \mathrm{Ra}$, a set of standards was also made for ${ }^{223}$ Ra by spiking sediments with a ${ }^{227}$ Ac solution. A set of filter standards and sediment standards were made for each transect to determine efficiencies based on sediment type (Figure 
S6). We ensured that moisture content and radioisotope counts were stable during the measurement. Values are reported as averages and standard deviations of at least 3 measurements. Bulk Ra isotopes were measured via gamma spectrometry as described above using 4-5 g of dried sediment packed into polystyrene vials. ${ }^{228} \mathrm{Ra}$ and ${ }^{226} \mathrm{Ra}$ were measured relative to a sediment standard (Certified Reference Material: IAEA-385). Analytical uncertainties are reported as $1 \sigma$.

\subsubsection{Meteorological and sea ice data}

To investigate the impacts of storm events during the cruise, we use sea level pressure (SLP) and $10 \mathrm{~m}$ wind speed data from the ECMWF Integrated Forecast System (IFS) ERA5 reanalysis product (Hersbach \& Dee, 2016). The spatial and temporal resolution are $0.25^{\circ}$ and 1 $\mathrm{hr}$, respectively. Wind speed and air temperature data were also downloaded from the Barrow Atmospheric Baseline Observatory (BABO) (NOAA Earth Systems Reach Laboratory, https://www.esrl.noaa.gov/gmd/obop/brw/) near Utqiagivik (formerly known as Barrow). To evaluate the reanalysis data compared to independent meteorological station data, we extracted the ERA5 data at the grid point closest to BABO and compared the two timeseries. Figure $3 \mathrm{a}$ shows the alongcoast windspeed from the ERA5 reanalysis and BABO, where the positive alongcoast direction is 105 degrees true. As shown by Nikolopoulos et al. (2009), the alongcoast winds are most highly correlated with the currents on the Beaufort shelf and slope. The two wind timeseries agree well in both phase and amplitude throughout the period of the cruise. The $2 \mathrm{~m}$ air temperature measured at BABO indicates that temperatures were less than $0^{\circ} \mathrm{C}$ throughout the study period (Figure $3 b$ ).

We use the Advanced Microwave Scanning Radiometer 2 (AMSR-2) data to characterize sea ice concentration over the shelf in autumn of 2018. AMSR-2 has a $6.25 \mathrm{~km}$ spatial resolution and daily temporal resolution. The data originate from the Global Change Observation Mission 1st-Water satellite, which measures seven frequency bands from 6.925 to $89.0 \mathrm{GHz}$ (Beitsch et al., 2014). The data were downloaded from the University of Bremen (http://www.iup.unibremen.de:8084/amsr2data/asi_daygrid_swath/n6250/2014/).

\subsection{Results}

This study centers around three storm events in November 2018. As noted in the introduction, upwelling events in the Beaufort Sea are most common in Oct-Nov (Lin et al., 2019; Pickart, Schulze, et al., 2013), and this year was no exception. The three events were defined using the alongcoast wind record (Figure 3a). Event \#1 was from Oct 30-Nov 1, event \#2 from Nov 3-7, and event \#3 from Nov 10-14. Hydrographic sampling was done during and between each of the events (Figure 3a). We first examine the atmospheric conditions during the events followed by characterization of the sea ice concentration and the occurrence of polynyas on the shelf. We then contrast the hydrographic conditions associated with these periods on the central Beaufort shelf, followed by radium isotopes and nutrients in the water column. Finally, radium isotopes in the shelf sediments are presented and compared to water column values to calculate time since SWI. 


\subsubsection{Wind events and sea ice concentration}

To understand the atmospheric circulation during the three events, we constructed composite SLP maps for each period (Figure 4) along with an enlarged view of the corresponding winds in the study region (Figure 5). This revealed that, even though each event was associated with easterly winds, they had different atmospheric patterns. Event \#1, which was very brief, had high pressure over the Beaufort Sea but was not associated with an Aleutian lowpressure system (in fact there was high pressure in the region of the Alaskan Peninsula, Figure 4a). Event \#2 also had a Beaufort High, but, in contrast to event \#1, had a weak Aleutian low in the Bering Sea with a trough of low pressure extending into the Gulf of Alaska (Figure 4b). The easterly winds were strongest for this event (Figure 5b), associated with the enhanced meridional gradient of SLP. However, this scenario does not correspond to the canonical case of an Aleutian low / Beaufort High identified by Pickart et al. (2009), since the SLP gradient in the southern Beaufort was supported in part by the local weak low-pressure trough situated south of the Beaufort coast.

The final event is the closest of the three cases to a canonical upwelling scenario in that there is a deep Aleutian low in the western Gulf of Alaska, together with high pressure in the Beaufort Sea. However, the high SLP is associated with a ridge extending from the East Siberian High (Figure 4c), not an isolated Beaufort High. This ridge is strong enough that it is acting as a blocking high which has prohibited the Aleutian low from progressing farther north. It is a wellknown pattern in winter (e.g. Wilson \& Overland, 1986), and is one of the two blocking scenarios discussed by Pickart et al. (2009) that can prevent the occurrence of upwelling. This is the reason that the winds are only moderately strong during the event (Figure 5c), despite the deep Aleutian Low. The wind threshold for upwelling (4-5 $\left.\mathrm{m} \mathrm{s}^{-1}\right)$ was reached in each of the cases (Figure 3). During event \#2 it exceeded $10 \mathrm{~m} \mathrm{~s}^{-1}$, which only occurs in about $25 \%$ of the storms in this region (Schulze \& Pickart, 2012).

Throughout the cruise, sea ice covered much of the Beaufort Sea and shelf. As discussed above, WW formation occurs due to refreezing in polynyas and leads (e.g. Jackson et al., 2015; Pacini et al., 2019). Here we define polynyas as areas where the ice concentration is $<80 \%$. In Figure 6, we show three snapshots of polynya presence in the study area during the cruise: one snapshot per event (we note that composite polynya maps are not as informative due to the averaging). During period 1, polynyas existed mainly on the innermost shelf, inshore of the hydrographic stations. During period 2, corresponding to the strongest easterly winds, polynyas were present across the full width of the shelf. In period 3, the polynya activity was mainly to the west of the study region, although polynyas were scattered along the edge of the shelf.

\subsubsection{Hydrographic observations}

We now present a subset of the hydrographic and velocity data obtained on the cruise that is relevant to the chemical results presented below. Figure 7 shows vertical sections of temperature, density, and absolute geostrophic velocity for three of the transects: section 148 which was occupied after period 1; section 147 which was occupied at the end of period 2; and 
section 150 which was occupied near the end of period 3 (Figure 3). In this study we define water colder than $-1.6^{\circ} \mathrm{C}$ as WW, consistent with previous studies (e.g. Pacini et al., 2019; Pickart et al., 2016).

On section 148 there is WW at the two inner-most stations on the shelf (Figure 7). This is consistent with an extended polynya along the inner-shelf during period 1 (Figure 6a) that likely resulted in the formation of this water. Beam transmission was lower at the two inner-most stations compared to the outer shelf (75-80\% and 90-95\%, respectively) indicative of high particle concentrations and substantial sediment resuspension. Phytoplankton blooms are unlikely during November due to light limitation (Pabi et al., 2008), so we rule out primary production as the main cause of high particle loads. The circulation was such that the eastwardflowing shelfbreak jet was re-established following period 1, and there was eastward flow on the shelf (even though event \#1 was brief, it was able to reverse the shelfbreak jet, not shown).

During period 2, WW was present over much of the shelf (the first 7 stations, Figure 7). Particle concentrations were still highest at the inner-most stations on the shelf, coincident with the coldest WW, but lower than period 1. This section was done after the period of strongest easterly winds, which likely induced upwelling and reversed the shelfbreak jet. One sees evidence of the upwelling by the presence of the warm, dense near-bottom layer extending roughly $30 \mathrm{~km}$ inshore of the shelfbreak. The flow on the shelf was still directed to the west in response to the previous easterly winds, but in the vicinity of the shelfbreak the westward flow was confined to the upper part of the water column (Figure 7). Below 25m there was eastward flow at the shelfbreak, intensifying with depth. This is the so-called "rebound jet" that regularly spins up at the end of an upwelling event (Li et al., 2020; Pickart et al., 2011), due to the disparity in the barotropic and baroclinic shelf wave speeds following the cessation of the easterly winds (Pickart et al., 2011).

Section 150 was occupied near the end of the period 3 easterly winds. These winds were substantially weaker than the period 2 easterly winds (Figure 3a), and the hydrographic sections show no evidence of upwelling inshore of the shelfbreak (Figure 7). WW again occupied most of the shelf (the first 9 stations), but, in contrast to period 2, it was present throughout the water column. The region of very cold WW $\left(<-1.7^{\circ} \mathrm{C}\right)$ also extended farther offshore. The plume of very cold $\mathrm{WW}$ at $\sim 60 \mathrm{~km}$ from shore coincided with the polynya at the shelf edge during period 3 (Figure 6c). Beam transmission was again lower on the inner shelf, with extremely low values of 20-30\% at the inner shelf stations where the coldest WW was found, indicating very high particle concentrations (Figure 7). The absolute geostrophic velocity shows westward flow across the entire section, with surface-intensified flow at the shelfbreak (Figure 7). In this case the rebound jet had not yet begun to appear since the winds were still out of the east.

\subsubsection{Radium isotopes \& nutrients}

Radium-228 and the ${ }^{228} \mathrm{Ra} /{ }^{226} \mathrm{Ra}$ activity ratio (AR) were both higher in shelf bottom waters than over the slope subsequent to period 1 (Figure 8 ). ${ }^{228} \mathrm{Ra}$ activities were $9.5 \pm 0.9$ and 
$7.9 \pm 0.5 \mathrm{dpm} 100 \mathrm{~L}^{-1}$ on the shelf and on the slope, respectively. The ${ }^{228} \mathrm{Ra} /{ }^{226} \mathrm{Ra} A \mathrm{R}$ was $0.79 \pm$ 0.04 and $0.68 \pm 0.05$ on the shelf and on the slope, respectively. In surface waters, ${ }^{228} \mathrm{Ra}$ activities and the ${ }^{228} \mathrm{Ra} /{ }^{226} \mathrm{Ra}$ AR were similar on the shelf and over the slope, with values of 8.2 $\pm 0.3 \mathrm{dpm} 100 \mathrm{~L}^{-1}$ and $0.71 \pm 0.05$, respectively. During period 2, we observed that ${ }^{228} \mathrm{Ra}$ in shelf bottom waters was $8.6 \pm 0.5 \mathrm{dpm} 100 \mathrm{~L}^{-1}$, similar to the end of period 1 . By period $3,{ }^{228} \mathrm{Ra}$ in bottom waters increased to $10.7 \pm 0.8 \mathrm{dpm} 100 \mathrm{~L}^{-1}$. The ${ }^{228} \mathrm{Ra} /{ }^{226} \mathrm{Ra}$ ratio on the shelf decreased from $0.79 \pm 0.04$ to $0.69 \pm 0.04$ from the end of period 1 to period 2 , and then increased to $0.82 \pm$ 0.07 , with a maximum value of 0.91 by period 3 . In surface waters on the central Beaufort shelf, ${ }^{228} \mathrm{Ra}$ increased from $8.2 \pm 0.3 \mathrm{dpm} 100 \mathrm{~L}^{-1}$ to $10.3 \pm 0.5 \mathrm{dpm} 100 \mathrm{~L}^{-1}$ from post-period 1 to period 3. Similarly, the surface ${ }^{228} \mathrm{Ra} /{ }^{226} \mathrm{Ra} A R$ increased from $0.71 \pm 0.05$ to $0.80 \pm 0.04$. The increase in surface water activities caused an increase in the surface to bottom water ratios of ${ }^{228} \mathrm{Ra}$ and ${ }^{228} \mathrm{Ra} /{ }^{226} \mathrm{Ra}$ AR (Figure 8). The observed ${ }^{228} \mathrm{Ra}$ activities during all periods were within the range of historical samples from the late 1990s and early 2000s (Kadko et al., 2008; Kadko \& Muench, 2005; Kipp et al., 2019; Smith et al., 2003; Trimble et al., 2004), and higher than the ${ }^{228} \mathrm{Ra}$ activities measured to the east during period 2 of this study (Figure 9). With the exception of the 1995 samples from the Canadian Beaufort shelf, all of the historical samples were collected slightly to the west of our study region.

Short-lived radium isotopes were also measured in the central Beaufort Sea. For both ${ }^{224} \mathrm{Ra}_{\mathrm{ex}}$ and ${ }^{223} \mathrm{Ra}_{\mathrm{ex}}$, activities were generally higher at depth than in surface waters, with the exception of one ${ }^{223} \mathrm{Ra}_{\mathrm{ex}}$ sample in period 3 (Figure 8). Following period 1, when we sampled both the shelf and over the slope, we observed that ${ }^{224} \mathrm{Ra}$ ex at depth was higher on the shelf, at 5$7 \mathrm{dpm} 100 \mathrm{~L}^{-1}$, compared to slope activities of $3.8 \mathrm{dpm} 100 \mathrm{~L}^{-1} \cdot{ }^{223} \mathrm{Ra}_{\mathrm{ex}}$ was also higher in shelf bottom waters than along the same density surfaces in the basin, with activities of 0.22 and 0.10 dpm $100 \mathrm{~L}^{-1}$, respectively. The ${ }^{224} \mathrm{Ra}_{\mathrm{ex}} /{ }^{223} \mathrm{Ra}_{\mathrm{ex}}$ AR was approximately $20-25$ on the shelf after period 1 (Figure 8). During period 2, we observed significantly higher ${ }^{224} \mathrm{Ra}_{\mathrm{ex}}$ in bottom waters

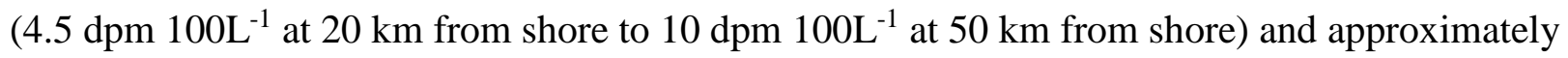
equivalent activities of ${ }^{223} \operatorname{Ra}_{\mathrm{ex}}\left(0.17-0.27 \mathrm{dpm} 100 \mathrm{~L}^{-1}\right)$, with the highest activities at $50 \mathrm{~km}$

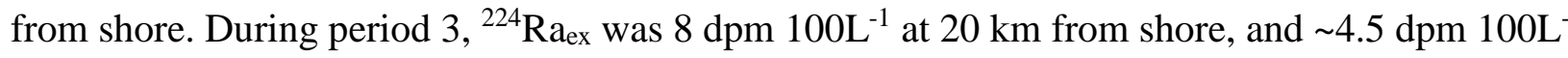
${ }^{1}$ on the outer shelf. One sample at $50 \mathrm{~km}$ from shore had ${ }^{224} \mathrm{Ra}_{\mathrm{ex}}$ activities of $11 \mathrm{dpm} 100 \mathrm{~L}^{-1}$. ${ }^{223} \mathrm{Ra}_{\mathrm{ex}}$ in bottom waters increased to $0.21-0.31 \mathrm{dpm} 100 \mathrm{~L}^{-1}$ by period 3 . The difference between surface and bottom water activities of ${ }^{224} \mathrm{Ra}$ and ${ }^{223} \mathrm{Ra}$ decreased from post period 1 to period 3, reflected in the strong increase in the surface-to-bottom water ratio of the isotopes (Figure 8). The ${ }^{224} \mathrm{Ra}_{\mathrm{ex}} /{ }^{223} \mathrm{Ra}_{\mathrm{ex}} \mathrm{AR}$ was highest at the shelf edge during period 2 (Figure 8).

Radium isotope activities were compared to ammonium concentrations in the water column during periods 1-3 (Figure 10). Statistically significant (95\% confidence level, $P$-value $<$ 0.05 ) relationships were found for ${ }^{228} \mathrm{Ra}$ and ${ }^{223} \mathrm{Ra}$ ex. There was not a statistically significant relationship for ${ }^{226} \mathrm{Ra}$ or ${ }^{224} \mathrm{Ra}$ ex with ammonium. Ammonium concentrations in shelf bottom waters consistently increased from periods 1 through 3 in the central Beaufort (Figure 10-11). In period $1, \mathrm{NH}_{4}{ }^{+}$concentrations were $\sim 0-0.5 \mu \mathrm{M}$. Surface waters were similarly depleted in $\mathrm{NH}_{4}{ }^{+}$. 
Concentrations increased to $0.8-2.0 \mu \mathrm{M}$, with the highest concentration at $45 \mathrm{~km}$ from shore. Surface waters were still depleted, with the exception of one surface sample with a concentration of $1.4 \mu \mathrm{M}$ at $30 \mathrm{~km}$ from shore. During period $3, \mathrm{NH}_{4}{ }^{+}$concentrations were $\sim 2 \mu \mathrm{M}$ at a distance of 20-30 km from shore, nearly $4 \mu \mathrm{M}$ at $\sim 40 \mathrm{~km}$ from shore, coinciding with very high particle concentrations (Figure 7), and approximately 0.6-1.3 $\mu \mathrm{M}$ at $40 \mathrm{~km}$ from shore to the shelfbreak (Figure 11). Surface waters were on average higher in $\mathrm{NH}_{4}{ }^{+}$during period 3 compared to the previous periods.

\subsubsection{Sediments}

Bulk surface sediments were collected along most transects and analyzed for radium isotopes. The surface-available ${ }^{224} \mathrm{Ra} /{ }^{223} \mathrm{Ra}$ ratio was within analytical error along a transect from the inner to outer shelf (Figure 12a). The ratios were 19 to 47 across the Beaufort shelf, with little variation beyond analytical uncertainties (Figure 12a). ${ }^{224} \mathrm{Ra} /{ }^{223} \mathrm{Ra}$ ARs were greater than those of Mediterranean beach sands and less than Tolo Harbor (Hong Kong) sediments measured using similar methods, and slightly enriched compared to average bulk continental crust (Liu et al., 2018; Tamborski et al., 2019).

Activities of ${ }^{226} \mathrm{Ra}$ in bulk surface sediments were 1.2-2 $\mathrm{dpm} \mathrm{g}^{-1}$ (Figure 12b), with a decreasing trend from inner to outer shelf along Section 152 and Section 140, and increasing from inner to outer shelf along sections 148 and $144 .{ }^{228} \mathrm{Ra}$ activities in bulk sediment were 1-2.6 $\mathrm{dpm} \mathrm{g}^{-1}$ (Figure 12c). Similar along-section trends in ${ }^{228} \mathrm{Ra}$ were observed as compared to ${ }^{226} \mathrm{Ra}$. The ${ }^{228} \mathrm{Ra} /{ }^{226} \mathrm{Ra}$ AR was $0.8-1.4$, and on average higher in the eastern sections $\left(140-144^{\circ} \mathrm{W}\right)$ than in the western transects $\left(148-152^{\circ} \mathrm{W}\right)$ (Figure 12d). These eastern transects are likely influenced by the Mackenzie River (Goñi et al., 2013); however, the focus of this paper is in the region farther to the west at longitudes $147-151^{\circ} \mathrm{W}$.

\subsubsection{Radium ages}

Since sediments are the main source of short-lived radium isotopes in the water column, we can calculate the age of the water, $t$, or time since SWI occurred, using the following equation (Moore, 2000b):

$$
{\frac{}{{ }^{224} R a}}_{{ }^{223} R a_{o b s}}=\frac{{ }^{224} R a}{{ }^{223} R a_{i}} \times \frac{e^{-\lambda_{224} t}}{e^{-\lambda_{223} t}} .
$$

(Equation 1)

${ }^{224} \mathrm{Ra} /{ }^{223} \mathrm{Ra} \mathrm{a}_{\text {obs }}$ is the observed water column ratio, ${ }^{224} \mathrm{Ra} /{ }^{223} \mathrm{Ra}_{\mathrm{i}}$ is the initial AR found in surface sediments (from Figure 12), and $\lambda_{224}$ and $\lambda_{223}$ are the decay constants, equal to 0.189 and $0.061 \mathrm{~d}^{-}$ ${ }^{1}$, respectively. In this model we assume that bottom sediment porewaters are in equilibrium with surfaces of the sediments, and that bottom sediments are the main source of ${ }^{223} \mathrm{Ra}_{\mathrm{ex}}$ and ${ }^{224} \mathrm{Ra}$ ex in the water column. Samples with greater than $50 \%$ relative error were excluded from the calculation. From post-period 1 to period 2, ages decreased from 2.3-5.4 days to 0.9-4.1 days (Figure 13). Ages of bottom water on the shelf then increased to 5.0 to 7.9 days from period 2 to 
3 , with the exception of one very young sample at $\sim 60 \mathrm{~km}$ from shore that had an age of $\sim 0.1$ days.

\subsection{Discussion}

\subsubsection{Tracers of sediment-water interaction}

During the cruise, we occupied the Beaufort shelf during three periods with contrasting physical conditions as presented above in November of 2018: 1) following a brief and moderate upwelling storm with polynyas present mainly along the coast; 2) at the end of a strong upwelling storm associated with extensive polynya presence across the central shelf; and 3) near the end of a weak upwelling storm with higher ice concentrations and polynyas only present at the outer shelf. Below we discuss the physical response of the water column to these drivers and the expected impact on SWI.

Radium isotopes can be used as tracers of SWI on continental shelves. Most surface sediments collected on the cruise had ${ }^{228} \mathrm{Ra} /{ }^{226} \mathrm{Ra}$ ARs greater than 1 (Figure 12). Typically, waters on the Beaufort shelf and in the Canada Basin have ${ }^{228} \mathrm{Ra} /{ }^{226} \mathrm{Ra}$ ratios $\leq 1$ (Kadko et al., 2008; Kadko \& Muench, 2005; Smith et al., 2003; Trimble et al., 2004), so increases of water column ARs towards 1 or more indicate influence from sediments. SWI causes increases in

${ }^{228} \mathrm{Ra}$, and has been well characterized as a tracer on the Chukchi shelf (Kipp et al., 2020; Vieira et al., 2019).

The short-lived radium isotopes ${ }^{224} \mathrm{Ra}$ and ${ }^{223} \mathrm{Ra}$ have a similar sediment source, but their distribution is influenced by decay on timescales of days to weeks (Colbert \& Hammond, 2008; Hancock et al., 2000; Moore et al., 2006). Ammonium produced in sediments can also be released simultaneously into coastal waters due to SWI (Bianchi et al., 1997; Z. W. Brown et al., 2015; Moore et al., 2019). Sediment-derived ammonium is similarly short-lived to ${ }^{223} \mathrm{Ra}$ and

${ }^{224} \mathrm{Ra}$, though its loss is due to biological processes in the water column (Lee et al., 2010; Tremblay et al., 2006). Together, these tracers have low backgrounds in the water column, which makes them more sensitive than ${ }^{228} \mathrm{Ra}$ or ${ }^{226} \mathrm{Ra}$ to recent SWI (Ardyna et al., 2017; Bianchi et al., 1997; Charette et al., 2008; Ku \& Luo, 2008; Moore, 2000b). In general, ${ }^{228} \mathrm{Ra}$ is useful as a tracer of the total amount of SWI, while ${ }^{224} \mathrm{Ra}$ and ${ }^{223} \mathrm{Ra}$ add in complementary information about the timing of SWI on the order of days.

\subsubsection{Post-Period 1 (Nov 2-3, 2018): Inner shelf WW formation}

The typical flow on the outer Alaskan Beaufort shelf and upper slope is towards the east, associated with the Beaufort shelfbreak jet (Nikolopoulos et al., 2009; Pickart, 2004). On the mid-shelf there have been no long-term mooring measurements, although data from a year-long array (2008-9) near $150^{\circ} \mathrm{W}$ showed westward mean flow on the mid and inner shelf (Weingartner et al., 2017). Wind events, such as storms with strong easterly winds that are common in autumn, can reverse the shelfbreak jet and intensify the westward flow on the midshelf (Lin et al., 2020). These events commonly lead to upwelling of water from the slope onto the shelf (Pickart et al., 2009, 2011; Pickart, Spall, et al., 2013). Prior to the occupation of 
section 148, there was a brief storm (i.e. Period 1), lasting about 1.5 days (Figures 3 and 14), with conditions that would favor upwelling. However, there is no compelling evidence that significant upwelling took place (Figure 7), other than an upward-sloping $25.5 \mathrm{~kg} \mathrm{~m}^{-3}$ isopycnal from the slope to the outer shelf. According to the absolute geostrophic velocity profiles (Figure 7 ), we observed that the shelfbreak jet was flowing to the east, and the flow on the shelf was directed eastward as well. The average sea ice concentrations in the study area were the lowest of the three periods, $\sim 60-70 \%$ (Figure 14). Large polynyas were present at this time along the inner shelf, consistent with the observations of WW at the two shoreward-most stations on section 148.

During this period, ${ }^{228} \mathrm{Ra}$ and the ${ }^{228} \mathrm{Ra} /{ }^{226} \mathrm{Ra}$ AR in bottom waters were slightly elevated at the inner shelf compared to the outer shelf (Figure 8), coinciding with the presence and lack of WW, respectively. In surface waters, all 4 radium isotopes were at lower activities than in bottom waters. The elevation of ${ }^{228} \mathrm{Ra}$ at the inner shelf and presence of WW also coincided with high particle concentrations, suggestive of bottom sediments having been recently resuspended due to brine rejection, which would also release ${ }^{228} \mathrm{Ra}$ into the water column. The elevation of ${ }^{228} \mathrm{Ra}$ is within the range of previous studies, but lower than subsequent sampling periods during this study (Figures 8 and 14) when WW formation was more prevalent across the entire study domain.

\subsubsection{Period 2 (Nov 3-7, 2018): Storm 2 and central shelf WW formation}

During Period 2, there were strong easterly winds that drove upwelling onto the Beaufort shelf (Figures 3 and 14). Here we focus on the central Beaufort shelf at Section 147 sampled on Nov 7, and exclude sections 139 and 144 that were significantly farther east (Figure 2).

Presumably, the shelfbreak jet was reversed due to this strong easterly wind event. As the winds relaxed and the section was occupied at the end of the event, the rebound jet appeared and the shelfbreak jet was in the process of returning to its normal condition of eastward flow. Water from the slope was present in a thin bottom layer extending well onto the shelf (Figure 7) which was in the process of flowing back off the shelf during the occupation of the section (Figure S3). Polynyas developed across much of the shelf (Figure 6), consistent with the sustained easterly winds that opened up leads in the ice. This is reflected in the decrease in mean sea ice concentration during the event (Figure 14). The re-freezing of the polynyas likely drove convection and formation of WW, consistent with the observations of WW over most of the shelf (Figure 7). There are two potential interpretations of the warm dense bottom layer on the shelf: 1) WW driven convection occurred after upwelling and did not penetrate bottom waters, and 2) WW driven convection occurred first followed by upwelling of slope water. Brine-driven overturning on the Chukchi shelf can reach the bottom on timescales of minutes to hours (Pacini et al., 2019), and the central Beaufort shelf is roughly the same depth as the Chukchi shelf, so it is likely that convectively formed WW did reach the bottom prior to the upwelling, resulting in active SWI at the central shelf stations. Further, the onset of upwelling typically lags behind an easterly wind even by about 18 hours on average (Pickart et al., 2009), so we expect that scenario 
2 is more likely. We therefore expect to see chemical signals of SWI interaction on the central shelf.

From post-period 1 to period 2, we observed similar ${ }^{228} \mathrm{Ra} /{ }^{226} \mathrm{Ra}$ ARs and a slight increase in average ${ }^{228} \mathrm{Ra}$ (Figures 8 and 14), but saw a significant increase in ${ }^{224} \mathrm{Ra}$ and ${ }^{224} \mathrm{Ra} /{ }^{223} \mathrm{Ra}$ in bottom waters (Figure 8 ), likely due to the difference in the sensitivity of these tracers to SWI in this region. Ammonium, also increased in surface waters at $30 \mathrm{~km}$ from shore and in several bottom water samples at 40-60 km from shore (Figure 11). Radium age decreased from 2-3 days to 1-2 days (Figure 13), due to ${ }^{224}$ Ra activities increasing by nearly $50 \%$ at this location (Figure 8), which overlaps with the location of increased $\mathrm{NH}_{4}{ }^{+}$concentrations (Figure 11) and with the presence of WW (Figure 7). This suggests that re-freezing in the polynyas likely caused strong enough vertical convection to reach the bottom and induce SWI, supporting the second scenario described above. Since this was also at the end of a strong storm event, we cannot rule out the influence of winds on vertical convection, especially since mobile sea ice can enhance the surface stress imparted to the water column (Martin et al., 2014; Pickart et al., 2011). The easterly winds also likely drove the opening of the polynyas, allowing for WW formation. Thus, the observed chemical response may be due to the combined drivers of wind and buoyancy.

\subsubsection{Period 3 (Nov 10-14): Storm 3 and WW development}

Section 150 was occupied near the end of period 3, corresponding to another period of easterly winds (Figures 3 and 14). However, unlike the previous storm, the winds during this event barely reached the $4-5 \mathrm{~m} \mathrm{~s}^{-1}$ threshold for upwelling, and while the shelfbreak jet was reversed, there was no indication of transport of slope waters onto the shelf. During period 3, highly concentrated sea ice covered most of the central Beaufort shelf (Figure 14) except in the vicinity of the shelfbreak where there were numerous polynyas (Figure 6). At the same time, the previously formed WW on the inner and central shelf should tend to progress offshore (Gawarkiewicz \& Chapman, 1995), although this could be influenced by wind. Interestingly, we observed the presence of very cold $\left(<-1.75^{\circ} \mathrm{C}\right) \mathrm{WW}$ at one of the stations near the shelfbreak ( $60 \mathrm{~km}$ from shore, Figure 7 ) in the very region of the polynyas (Figure 6). The inner shelf WW coincided with highly turbid waters (Figure 7). This could be due to continued convection in this region, which began during period 1, or to the lateral advection of the very dense water as it flows along the bottom after convection (Gawarkiewicz \& Chapman, 1995), both of which likely have the potential to resuspend sediments.

Across the shelf during period 3, we observed significant changes in both radium isotopes and ammonium. There were meaningful increases in the ${ }^{228} \mathrm{Ra} /{ }^{226} \mathrm{Ra} \mathrm{AR}$ and ${ }^{228} \mathrm{Ra}$ in both bottom and surface waters compared to the earlier periods (Figure 8). Increases in the surface to bottom water ratio of all radium isotopes is indicative of decreased stratification across the shelf where there was buoyancy-driven sediment resuspension and extensive WW formation (Figure 7). We note that the strong westward currents during this time would transport water from the east at $35-40 \mathrm{~km} \mathrm{~d}^{-1}$, so in addition to local SWI, we might expect chemical signals to also be 
influenced by shelf waters that originated in the eastern Beaufort. However, the lower ${ }^{228} \mathrm{Ra}$ activities in the eastern Beaufort during this study and in 1995 compared to western Beaufort historical samples and samples from periods 1-3 (Figures 9 and S4) suggest that typical summer and autumn shelf waters from the eastern Beaufort are depleted in radium isotopes. Therefore, the increase in ${ }^{228} \mathrm{Ra}$ that we observe is likely due to recent and local SWI. We expect that ${ }^{228} \mathrm{Ra}$ may increase further during the ice-covered months as polynyas form and cause continued SWI, as modeled in the Chukchi Sea by Kipp et al. (2020), until a new steady-state is reached where off-shelf mixing losses prevent further rise in concentration over the shelf.

During all study periods, ${ }^{223} \mathrm{Ra}$ ex and ${ }^{228} \mathrm{Ra}$ were linearly correlated with ammonium concentrations, showing their shared sediment source (Figure 10). Ammonium was highly enriched in bottom waters at 20-30 km from shore, especially in the nepheloid layer with extremely low beam transmission (Figure 7), and at elevated concentrations throughout the water column at $60 \mathrm{~km}$ from shore (Figure 11), coinciding spatially with plumes of WW (Figure 7). The average $\mathrm{NH}_{4}{ }^{+}$concentrations on the central shelf $(30-60 \mathrm{~km}$ from shore, full water column profiles) increased from 0.4 to $1.0 \mu \mathrm{M}$ from post-period 1 to period 3 (Figure 11). Combined, the long-lived isotopes and ammonium show strong evidence of SWI coinciding with WW developing over the two-week timeseries.

Increases of ${ }^{228} \mathrm{Ra}$ with time provide evidence of increasing SWI due to WW formation, while short-lived radium isotopes provide details about the timing of the SWI event and speed of convection. From period 2 to 3, radium age increased from 1-4 days to 5-9 days at the inner shelf where the coldest and most well-mixed WW was observed (Figure 13). This suggests that the enrichment in the long-lived radium isotopes and ammonium, that began during period 2 , had continued beyond that time until our return to the central Beaufort shelf. Then when we occupied section 150 on Nov 12-13, the short-lived radium isotopes that were released at the end of period 2 had decayed. The exception to this was at the station $60 \mathrm{~km}$ from shore, where we observed the isolated patch of WW beneath the region of polynyas (Figure 7). Here the radium age was <1 day in bottom waters (Figure 13), which indicates that the station was occupied very close to the time of active convection. This rapid, buoyancy-driven convection is consistent with overturning timescales of hours during WW formation in the Chukchi Sea (Pacini et al., 2019).

\subsection{Conclusion}

The timeseries presented in this study is among the first to document the combined physical and chemical signals of winter water formation in the Beaufort Sea, made possible by repeat occupations of the central Beaufort shelf over a two-week time period in November 2018. In addition to year-round mooring observations (Itoh et al., 2012; Weingartner et al., 1998), late spring cruises (Pacini et al., 2019; Vieira et al., 2019), and modeling evidence (Kipp et al., 2020), this study highlights the patchiness of the ice formation process and its ability to drive dissolved constituents from sediment porewaters into the water column not only during autumn, but also throughout winter to early spring. It further suggests that these SWI events are episodic in nature, and that mesoscale water column features can drive local exchange with the benthos. Future 
studies may be able to use these isotopes as tracers to monitor changes in the sedimentary sources of nutrients. Large inputs of ammonium were observed, which presumably occur throughout the winter and spring as leads in the ice allow for more ice formation (Reimnitz et al., 1994). The ammonium produced during winter water formation in ice covered months is likely converted to nitrate by nitrification (Shiozaki et al., 2019) which can feed spring blooms on the shelf (Tremblay et al., 2006) and in the basin as water is transported offshore (Vieira et al., 2019).

Climate change is causing increases in primary production in the Arctic Ocean: in the early 2000s, areas of primary production increased due to decreases in sea ice and light limitation (Ardyna et al., 2014; Arrigo et al., 2008; Lewis et al., 2020). Since 2008, continued increases in primary production were driven largely by increases in biomass rather than open water area, likely due to an influx of new nutrients (Lewis et al., 2020). As the climate continues to warm, our study suggests that sediment-water exchange processes during winter water formation, will become a crucial source of nutrients that continues to support increases in productivity in the Arctic. Other drivers of sediment-water interaction, such as wind and potentially submarine groundwater discharge, which has not been well characterized in the Arctic (Lecher, 2017), are likely to increase over time (Rainville et al., 2011; Walvoord \& Kurylyk, 2016). High temporal resolution of radium isotope measurements and nutrients via moorings or autonomous platforms could further elucidate the drivers of sediment-water interaction throughout the year and help quantify nutrient inputs that are driving increases in primary productivity (Lewis et al., 2020). Increases in total shelf inputs to the central Arctic have been observed for ${ }^{228} \mathrm{Ra}$ and other trace elements and isotopes with sediment sources (Charette et al., 2020; Kipp et al., 2018; Rutgers van der Loeff et al., 2018), but disentangling the changes due to river inputs versus shelf processes can allow us to predict future changes in biogeochemical cycles in the Arctic as it continues to warm at an unprecedented rate.

\section{Acknowledgements}

The authors would like to acknowledge the amazing work of Captain Greg Tlapa and the crew of the USGCG Healy during HLY1803. The authors acknowledge Joseph Tamborski for guidance and mentorship on sediment analyses, Paul Henderson for the nutrient analyses, Frank Bahr for the ADCP data analyses, Peigen Lin for providing much of the processed hydrographic data, and Astrid Pacini for her assistance with MATLAB. This work was funded by the Montrym Fund at the Massachusetts Institute of Technology, the Academic Programs Office at Woods Hole Oceanographic Institution, and the NSF Arctic GEOTRACES (OCE-1458305), Pacific GEOTRACES (OCE-1736277), and Arctic Observing Network (OPP-1733564) programs. 


\section{References}

Aagaard, K., Coachman, L. K., \& Carmack, E. (1981). On the halocline of the Arctic Ocean.

Deep Sea Research Part A, Oceanographic Research Papers, 28(6), 529-545.

https://doi.org/10.1016/0198-0149(81)90115-1

Ardyna, M., Babin, M., Gosselin, M., Devred, E., Rainville, L., \& Tremblay, J. É. (2014). Recent Arctic Ocean sea ice loss triggers novel fall phytoplankton blooms. Geophysical Research Letters, 41(17), 6207-6212. https://doi.org/10.1002/2014GL061047

Ardyna, M., Babin, M., Devred, E., Forest, A., Gosselin, M., Raimbault, P., \& Tremblay, J. (2017). Shelf-basin gradients shape ecological phytoplankton niches and community composition in the coastal Arctic Ocean (Beaufort Sea). Limnology and Oceanography, 62(5), 2113-2132. https://doi.org/10.1002//no.10554

Arrigo, K. R., van Dijken, G., \& Pabi, S. (2008). Impact of a shrinking Arctic ice cover on marine primary production. Geophysical Research Letters, 35(19).

https://doi.org/10.1029/2008GL035028

Bianchi, M., Feliatra, F., Tréguer, P., Vincendeau, M. A., \& Morvan, J. (1997). Nitrification rates, ammonium and nitrate distribution in upper layers of the water column and in sediments of the Indian sector of the Southern Ocean. Deep-Sea Research Part II: Topical Studies in Oceanography, 44(5), 1017-1032. https://doi.org/10.1016/S0967-0645(96)00109-9

Brown, Z. W., Casciotti, K. L., Pickart, R. S., Swift, J. H., \& Arrigo, K. R. (2015). Aspects of the marine nitrogen cycle of the Chukchi Sea shelf and Canada Basin. Deep-Sea Research Part II: Topical Studies in Oceanography, 118, 73-87. https://doi.org/10.1016/j.dsr2.2015.02.009

Bruland, K. W., \& Lohan, M. C. (2003). Controls of trace metals in seawater. In Treatise on Geochmistry (Vol. 6, pp. 23-47).

Cai, P., Shi, X., Moore, W. S., \& Dai, M. (2012). Measurement of 224Ra:228Th disequilibrium in coastal sediments using a delayed coincidence counter. Marine Chemistry, 138-139, 1-6. https://doi.org/10.1016/j.marchem.2012.05.004

Carmack, E. C., \& Chapman, D. C. (2003). Wind-driven shelf/basin exchange on an Arctic shelf: The joint roles of ice cover extent and shelf-break bathymetry. Geophysical Research Letters, 30(14). https://doi.org/10.1029/2003GL017526

Charette, M. A., Moore, W. S., \& Burnett, W. C. (2008). Uranium-and Thorium-Series Nuclides as Tracers of Submarine Groundwater Discharge. Radioactivity in the Environment, 13, 155191.

Charette, M. A., Kipp, L. E., Jensen, L. T., Dabrowski, J. S., Whitmore, L. M., Fitzsimmons, J. N., et al. (2020). The Transpolar Drift as a Source of Riverine and Shelf-Derived Trace Elements to the Central Arctic Ocean. Journal of Geophysical Research: Oceans, (125), e2019JC015920. https://doi.org/10.1029/2019jc015920 
Cid, A. P., Nakatsuka, S., \& Sohrin, Y. (2012). Stoichiometry among bioactive trace metals in the Chukchi and Beaufort Seas. Journal of Oceanography, 68(6), 985-1001.

https://doi.org/10.1007/s10872-012-0150-8

Colbert, S. L., \& Hammond, D. E. (2008). Shoreline and seafloor fluxes of water and short-lived $\mathrm{Ra}$ isotopes to surface water of San Pedro Bay, CA. Marine Chemistry, 108(1-2), 1-17. https://doi.org/10.1016/j.marchem.2007.09.004

Cota, G. F., Pomeroy, L. R., Harrison, W. G., Jones, E. P., Peters, F., Sheldon, W. M., \& Weingartner, T. R. (1996). Nutrients, primary production and microbial heterotrophy in the southeastern Chukchi Sea: Arctic summer nutrient depletion and heterotrophy. Marine Ecology Progress Series, 135(1-3), 247-258. https://doi.org/10.3354/meps 135247

Foukal, N. P., Pickart, R. S., Moore, G. W. K., \& Lin, P. (2019). Shelfbreak Downwelling in the Alaskan Beaufort Sea. Journal of Geophysical Research: Oceans, 124(10), 7201-7225. https://doi.org/10.1029/2019JC015520

Gawarkiewicz, G., \& Chapman, D. C. (1995). A numerical study of dense water formation and transport on a shallow, sloping continental shelf. Journal of Geophysical Research, 100(C3), 4489-4507. https://doi.org/10.1029/94JC01742

Gong, D., \& Pickart, R. S. (2015). Summertime circulation in the eastern Chukchi Sea. Deep-Sea Research Part II: Topical Studies in Oceanography, 118, 18-31.

https://doi.org/10.1016/j.dsr2.2015.02.006

Goñi, M. A., Yunker, M. B., O’Connor, A. E., Kuzyk, Z. Z., Gobeil, C., \& Macdonald, R. W. (2013). Distribution and sources of organic matter in surface marine sediments across the North American Arctic margin. Journal of Geophysical Research: Oceans, 118(9), 4017-4035. https://doi.org/10.1002/jgrc.20286

Granger, J., Sigman, D. M., Gagnon, J., Tremblay, J. E., \& Mucci, A. (2018). On the Properties of the Arctic Halocline and Deep Water Masses of the Canada Basin from Nitrate Isotope Ratios. Journal of Geophysical Research: Oceans, 123(8). https://doi.org/10.1029/2018JC014110

Hancock, G. J., Webster, I. T., Ford, P. W., \& Moore, W. S. (2000). Using Ra isotopes to examine transport processes controlling benthic fluxes into a shallow estuarine lagoon. Geochimica et Cosmochimica Acta, 64(21), 3685-3699. https://doi.org/10.1016/S00167037(00)00469-5

Itoh, M., Shimada, K., Kamoshida, T., McLaughlin, F., Carmack, E., \& Nishino, S. (2012). Interannual variability of Pacific Winter Water inflow through Barrow Canyon from 2000 to 2006. Journal of Oceanography, 68(4), 575-592. https://doi.org/10.1007/s10872-012-0120-1

Jackson, J. M., Melling, H., Lukovich, J. V., Fissel, D., \& Barber, D. G. (2015). Formation of winter water on the Canadian Beaufort shelf: New insight from observations during 2009-2011. Journal of Geophysical Research C: Oceans, 120(6), 4090-4107. https://doi.org/10.1002/2015JC010812 
Jakobsson, M. (2002). Hypsometry and volume of the Arctic Ocean and its constituent seas. Geochemistry, Geophysics, Geosystems, 3(5), 1-18. https://doi.org/10.1029/2001GC000302

Jones, E. P., \& Anderson, L. G. (1986). On the origin of the chemical properties of the Arctic Ocean halocline. Journal of Geophysical Research, 91(C9), 10759.

https://doi.org/10.1029/JC091iC09p10759

Kadko, D., \& Muench, R. (2005). Evaluation of shelf-basin interaction in the western Arctic by use of short-lived radium isotopes: The importance of mesoscale processes. Deep-Sea Research Part II: Topical Studies in Oceanography, 52(24-26), 3227-3244. https://doi.org/10.1016/j.dsr2.2005.10.008

Kadko, D., Pickart, R. S., \& Mathis, J. (2008). Age characteristics of a shelf-break eddy in the western Arctic and implications for shelf-basin exchange. Journal of Geophysical Research, 113(C2), C02018. https://doi.org/10.1029/2007JC004429

Kipp, L. E., Charette, M. A., Moore, W. S., Henderson, P. B., \& Rigor, I. G. (2018). Increased fluxes of shelf-derived materials to the central Arctic Ocean. Science Advances, 4(1), 1-10. https://doi.org/10.1126/sciadv.aao1302

Kipp, L. E., Kadko, D. C., Pickart, R. S., Henderson, P. B., Moore, W. S., \& Charette, M. A. (2019). Shelf-basin interactions and water mass residence times in the Western Arctic Ocean: insights provided by radium isotopes. Journal of Geophysical Research: Oceans, 124(5), 2019JC014988. https://doi.org/10.1029/2019JC014988

Kipp, L. E., Spall, M. A., Pickart, R. S., Kadko, D. C., Moore, W. S., Dabrowski, J. S., \& Charette, M. A. (2020). Observational and Modeling Evidence of Seasonal Trends in SedimentDerived Material Inputs to the Chukchi Sea. Journal of Geophysical Research: Oceans, 125(5), 1-13. https://doi.org/10.1029/2019jc016007

Ku, T. L., \& Luo, S. (2008, January 1). Chapter 9 Ocean Circulation/Mixing Studies with DecaySeries Isotopes. Radioactivity in the Environment. Elsevier. https://doi.org/10.1016/S15694860(07)00009-5

Lecher, A. L. (2017). Groundwater Discharge in the Arctic: A Review of Studies and Implications for Biogeochemistry. Hydrology, 4(3), 41.

https://doi.org/10.3390/hydrology4030041

Lee, S. H., Stockwell, D., \& Whitledge, T. E. (2010). Uptake rates of dissolved inorganic carbon and nitrogen by under-ice phytoplankton in the Canada Basin in summer 2005. Polar Biology, 33(8), 1027-1036. https://doi.org/10.1007/s00300-010-0781-4

Lewis, K. M., van Dijken, G. L., \& Arrigo, K. R. (2020). Changes in phytoplankton concentration now drive increased Arctic Ocean primary production. Science (New York, N.Y.), 369(6500), 198-202. https://doi.org/10.1126/science.aay8380 
Li, J., Pickart, R. S., Lin, P., Bahr, F., Arrigo, K. R., Juranek, L., \& Yang, X. (2020). The Atlantic Water Boundary Current in the Chukchi Borderland and southern Canada Basin. Journal of Geophysical Research: Oceans. https://doi.org/10.1029/2020JC016197

Lin, P., Pickart, R. S., Moore, G. W. K., Spall, M. A., \& Hu, J. (2019). Characteristics and dynamics of wind-driven upwelling in the Alaskan Beaufort Sea based on six years of mooring data. Deep-Sea Research Part II: Topical Studies in Oceanography, 162, 79-92. https://doi.org/10.1016/j.dsr2.2018.01.002

Liu, Y., Jiao, J. J., Lang, W., \& Luo, X. (2018). Using Tidal Fluctuation-Induced Dynamics of Radium Isotopes (224Ra, 223Ra, and 228Ra) to Trace the Hydrodynamics and Geochemical Reactions in a Coastal Groundwater Mixing Zone. Water Resources Research, (54), 2909-2930. https://doi.org/10.1002/2017WR022456

Martin, T., Steele, M., \& Zhang, J. (2014). Seasonality and long-term trend of Arctic Ocean surface stress in a model. Journal of Geophysical Research: Oceans, 119(3), 1723-1738. https://doi.org/10.1002/2013JC009425@10.1002/(ISSN)2169-9291.FAMOS1

Moore, W. S. (2000). Ages of continental shelf waters determined from 223Ra and 224Ra. Journal of Geophysical Research: Oceans, 105(C9), 22117-22122. https://doi.org/10.1029/1999JC000289

Moore, W. S. (2010). The effect of submarine groundwater discharge on the ocean. Annual Review of Marine Science, 2, 59-88. https://doi.org/10.1146/annurev-marine-120308-081019

Moore, W. S., \& Arnold, R. (1996). Measurement of 223Ra and 224Ra in coastal waters using a delayed coincidence counter. Journal of Geophysical Research C: Oceans, 101(C1), 1321-1329. https://doi.org/10.1029/95JC03139

Moore, W. S., \& Reid, D. F. (1973). Extraction of radium from natural waters using manganeseimpregnated acrylic fibers. Journal of Geophysical Research, 78(36), 8880-8886. https://doi.org/10.1029/JC078i036p08880

Moore, W. S., Blanton, J. O., \& Joye, S. B. (2006). Estimates of flushing times, submarine groundwater discharge, and nutrient fluxes to Okatee Estuary, South Carolina. Journal of Geophysical Research: Oceans, 111(9), 1-14. https://doi.org/10.1029/2005JC003041

Moore, W. S., Humphries, M. S., Benitez-Nelson, C. R., Pillay, L., \& Higgs, C. (2019). Transport of Radium and Nutrients Through Eastern South African Beaches. Journal of Geophysical Research: Oceans, 124(3), 2010-2027. https://doi.org/10.1029/2018JC014772

Mulligan, A. E., \& Charette, M. A. (2006). Intercomparison of submarine groundwater discharge estimates from a sandy unconfined aquifer. Journal of Hydrology, 327(3-4), 411-425. https://doi.org/10.1016/J.JHYDROL.2005.11.056

Naidu, A. S., \& Mowatt, T. C. (1983). Sources and dispersal patterns of clay minerals in surface sediments from the continental-shelf areas off Alaska. Geological Society of America Bulletin, 94(7), 841-854. https://doi.org/10.1130/0016-7606(1983)94<841:SADPOC>2.0.CO;2 
Naidu, A. S., Cooper, L. W., Finney, B. P., Macdonald, R. W., Alexander, C., \& Semiletov, I. P. (2000). Organic carbon isotope ratio ( $\delta 13 \mathrm{C}$ ) of Arctic Amerasian Continental shelf sediments. International Journal of Earth Sciences, 89(3), 522-532. https://doi.org/10.1007/s005310000121

Nikolopoulos, A., Pickart, R. S., Fratantoni, P. S., Shimada, K., Torres, D. J., \& Jones, E. P. (2009). The western Arctic boundary current at $152^{\circ} \mathrm{W}$ : Structure, variability, and transport. Deep-Sea Research Part II: Topical Studies in Oceanography, 56(17), 1164-1181. https://doi.org/10.1016/j.dsr2.2008.10.014

Pabi, S., van Dijken, G. L., \& Arrigo, K. R. (2008). Primary production in the Arctic Ocean, 1998-2006. Journal of Geophysical Research: Oceans, 113(8).

https://doi.org/10.1029/2007JC004578

Pacini, A., Moore, G. W. K., Pickart, R. S., Nobre, C., Bahr, F., Våge, K., \& Arrigo, K. R. (2019). Characteristics and Transformation of Pacific Winter Water on the Chukchi Sea Shelf in Late Spring. Journal of Geophysical Research: Oceans, 124(10), 7153-7177.

https://doi.org/10.1029/2019JC015261

Pickart, R. S. (2004). Shelfbreak circulation in the Alaskan Beaufort Sea: Mean structure and variability. Journal of Geophysical Research C: Oceans, 109(4), 1-14.

https://doi.org/10.1029/2003JC001912

Pickart, R. S., Moore, G. W. K., Torres, D. J., Fratantoni, P. S., Goldsmith, R. A., \& Yang, J. (2009, September 17). Upwelling on the continental slope of the alaskan beaufort sea: Storms, ice, and oceanographic response. Journal of Geophysical Research: Oceans. Blackwell Publishing Ltd. https://doi.org/10.1029/2008JC005009

Pickart, R. S., Spall, M. A., Moore, G. W. K., Weingartner, T. J., Woodgate, R. A., Aagaard, K., \& Shimada, K. (2011). Upwelling in the Alaskan Beaufort Sea: Atmospheric forcing and local versus non-local response. Progress in Oceanography, 88(1-4), 78-100. https://doi.org/10.1016/j.pocean.2010.11.005

Pickart, R. S., Spall, M. A., \& Mathis, J. T. (2013). Dynamics of upwelling in the Alaskan Beaufort Sea and associated shelf-basin fluxes. Deep Sea Research Part I: Oceanographic Research Papers, 76, 35-51. https://doi.org/10.1016/J.DSR.2013.01.007

Pickart, R. S., Schulze, L. M., Moore, G. W. K., Charette, M. A., Arrigo, K. R., van Dijken, G., \& Danielson, S. L. (2013). Long-term trends of upwelling and impacts on primary productivity in the Alaskan Beaufort Sea. Deep-Sea Research Part I: Oceanographic Research Papers, 79, 106-121. https://doi.org/10.1016/j.dsr.2013.05.003

Pickart, R. S., Moore, G. W. K., Mao, C., Bahr, F., Nobre, C., \& Weingartner, T. J. (2016). Circulation of winter water on the Chukchi shelf in early Summer. Deep Sea Research Part II: Topical Studies in Oceanography, 130, 56-75. https://doi.org/10.1016/J.DSR2.2016.05.001

Rainville, L., Lee, C. M., \& Woodgate, R. A. (2011). Impact of wind-driven mixing in the Arctic Ocean. Oceanography, 24(3), 136-145. https://doi.org/10.5670/oceanog.2011.65 
Reimnitz, E., Dethleff, D., \& Nürnberg, D. (1994). Contrasts in Arctic shelf sea-ice regimes and some implications: Beaufort Sea versus Laptev Sea. Marine Geology, 119(3-4), 215-225. https://doi.org/10.1016/0025-3227(94)90182-1

Rutgers van der Loeff, M. M., Key, R. M., Scholten, J., Bauch, D., \& Michel, A. (1995). 228Ra as a tracer for shelf water in the Arctic ocean. Deep-Sea Research Part II, 42(6), 1533-1553. https://doi.org/10.1016/0967-0645(95)00053-4

Rutgers van der Loeff, M. M., Kühne, S., Wahsner, M., Höltzen, H., Frank, M., Ekwurzel, B., et al. (2003). 228Ra and226Ra in the Kara and Laptev seas. Continental Shelf Research, 23(1), 113-124. https://doi.org/10.1016/S0278-4343(02)00169-3

Rutgers van der Loeff, M. M., Cai, P., Stimac, I., Bauch, D., Hanfland, C., Roeske, T., \& Moran, S. B. (2012). Shelf-basin exchange times of Arctic surface waters estimated from 228Th/228Ra disequilibrium. Journal of Geophysical Research: Oceans, 117(3). https://doi.org/10.1029/2011JC007478

Rutgers van der Loeff, M. M., Kipp, L., Charette, M. A., Moore, W. S., Black, E., Stimac, I., et al. (2018). Radium Isotopes Across the Arctic Ocean Show Time Scales of Water Mass Ventilation and Increasing Shelf Inputs. Journal of Geophysical Research: Oceans, 123(7), 4853-4873. https://doi.org/10.1029/2018JC013888

Schulze, L. M., \& Pickart, R. S. (2012). Seasonal variation of upwelling in the Alaskan Beaufort Sea: Impact of sea ice cover. Journal of Geophysical Research: Oceans, 117(6). https://doi.org/10.1029/2012JC007985

Shen, Y., Benner, R., Robbins, L. L., \& Wynn, J. G. (2016). Sources, Distributions, and Dynamics of Dissolved Organic Matter in the Canada and Makarov Basins. Frontiers in Marine Science, 3. https://doi.org/10.3389/fmars.2016.00198

Shiozaki, T., Ijichi, M., Fujiwara, A., Makabe, A., Nishino, S., Yoshikawa, C., \& Harada, N. (2019). Factors Regulating Nitrification in the Arctic Ocean: Potential Impact of Sea Ice Reduction and Ocean Acidification. Global Biogeochemical Cycles, 33(8), 1085-1099. https://doi.org/10.1029/2018GB006068

Smith, J. N., Moran, S. B., \& Macdonald, R. W. (2003). Shelf-basin interactions in the Arctic Ocean based on $210 \mathrm{~Pb}$ and $\mathrm{Ra}$ isotope tracer distributions. Deep-Sea Research Part I: Oceanographic Research Papers, 50(3), 397-416. https://doi.org/10.1016/S0967-0637(02)001668

Tamborski, J., Beek, P. Van, Rodellas, V., Monnin, C., Bergsma, E., Stieglitz, T., et al. (2019). Temporal variability of lagoon - sea water exchange and seawater circulation through a Mediterranean barrier beach. Limnology and Oceanography, 2059-2080. https://doi.org/10.1002/lno.11169

Tremblay, J. É., Michel, C., Hobson, K. A., Gosselin, M., \& Price, N. M. (2006). Bloom dynamics in early opening waters of the Arctic Ocean. Limnology and Oceanography, 51(2), 900-912. https://doi.org/10.4319/lo.2006.51.2.0900 
Trimble, S. M., Baskaran, M., \& Porcelli, D. (2004). Scavenging of thorium isotopes in the Canada Basin of the Arctic Ocean. Earth and Planetary Science Letters, 222(3-4), 915-932. https://doi.org/10.1016/j.epsl.2004.03.027

Vieira, L. H., Achterberg, E. P., Scholten, J., Beck, A. J., Liebetrau, V., Mills, M. M., \& Arrigo, K. R. (2019). Benthic fluxes of trace metals in the Chukchi Sea and their transport into the Arctic Ocean. Marine Chemistry, 208, 43-55. https://doi.org/10.1016/j.marchem.2018.11.001

Walsh, J. E. (1978). Temporal and Spatial Scales of the Arctic Circulation. Monthly Weather Review (Vol. 106). American Meteorological Society. https://doi.org/10.1175/15200493(1978) 106<1532:TASSOT>2.0.CO;2

Walvoord, M. A., \& Kurylyk, B. L. (2016). Hydrologic Impacts of Thawing Permafrost-A Review. Vadose Zone Journal, 15(6), 1-20. https://doi.org/10.2136/vzj2016.01.0010

Webster, I. T., Hancock, G. J., \& Murray, A. S. (1995). Modelling the effect of salinity on radium desorption from sediments. Geochimica et Cosmochimica Acta, 59(12), 2469-2476. https://doi.org/10.1016/0016-7037(95)00141-7

Weingartner, T. J., Cavalieri, D. J., Aagaard, K., \& Sasaki, Y. (1998). Circulation, dense water formation, and outflow on the northeast Chukchi shelf. Journal of Geophysical Research C: Oceans, 103(3334), 7647-7661. https://doi.org/10.1029/98jc00374

Weingartner, T. J., Danielson, S. L., Potter, R. A., Trefry, J. H., Mahoney, A., Savoie, M., et al. (2017). Circulation and water properties in the landfast ice zone of the Alaskan Beaufort Sea. Continental Shelf Research, 148, 185-198. https://doi.org/10.1016/j.csr.2017.09.001

Williams, W. J., \& Carmack, E. C. (2015). The "interior" shelves of the Arctic Ocean: Physical oceanographic setting, climatology and effects of sea-ice retreat on cross-shelf exchange.

Progress in Oceanography, 139, 24-41. https://doi.org/10.1016/j.pocean.2015.07.008

Wilson, J. G., \& Overland, J. E. (1986). Meteorology of the northern Gulf of Alaska. In D. W. Hood \& S. T. Zimmerman (Eds.), The Gulf of Alaska: Physical Environment and Biological Resources (pp. 31-54). Washington, DC: U.S. Department of Commerce. 
Table 1 Radium isotope samples from cruise HLY1803, Oct-Nov 2018.

\begin{tabular}{|c|c|c|c|c|c|c|c|c|c|c|c|}
\hline $\begin{array}{l}\text { Lat } \\
\left({ }^{\circ} \mathbf{N}\right)\end{array}$ & $\begin{array}{l}\text { Lon } \\
\left({ }^{\circ} \mathbf{W}\right)\end{array}$ & $\begin{array}{c}\text { Depth } \\
\text { (m) }\end{array}$ & $\begin{array}{c}\text { Time } \\
\text { (GMT) }\end{array}$ & $\begin{array}{c}{ }^{224} \mathbf{R a}_{\mathrm{xs}} \\
(\mathrm{dpm} \\
\left.100 \mathrm{~L}^{-1}\right)\end{array}$ & \pm & $\begin{array}{c}{ }^{223} \mathrm{Ra}_{\mathrm{xs}} \\
(\mathrm{dpm} \\
\left.100 \mathrm{~L}^{-1}\right)\end{array}$ & \pm & $\begin{array}{c}{ }^{228} \mathrm{Ra} \\
(\mathrm{dpm} \\
\left.100 \mathrm{~L}^{-1}\right)\end{array}$ & \pm & $\begin{array}{c}{ }^{226} \mathrm{Ra} \\
(\mathrm{dpm} \\
\left.100 \mathrm{~L}^{-1}\right)\end{array}$ & \pm \\
\hline 66.725 & 168.430 & 1.0 & $\begin{array}{c}10 / 28 / 18 \\
23: 21\end{array}$ & 6.86 & 0.17 & 0.44 & 0.05 & 15.6 & 1.0 & 11.3 & 0.2 \\
\hline 66.725 & 168.430 & 29.1 & $\begin{array}{c}10 / 28 / 18 \\
22: 46\end{array}$ & 21.31 & 0.51 & 2.03 & 0.15 & 16.1 & 1.0 & 12.0 & 0.2 \\
\hline 71.164 & 152.252 & 24.4 & $\begin{array}{c}10 / 30 / 18 \\
13: 23 \\
\end{array}$ & 6.57 & 0.19 & 0.27 & 0.04 & 12.1 & 0.5 & 11.9 & 0.1 \\
\hline 71.248 & 152.163 & 1.0 & $\begin{array}{c}10 / 30 / 18 \\
16: 00 \\
\end{array}$ & 3.49 & 0.19 & 0.16 & 0.04 & 9.4 & 1.0 & 11.2 & 0.3 \\
\hline 71.248 & 152.163 & 41.2 & $\begin{array}{c}10 / 30 / 18 \\
15: 46\end{array}$ & 6.36 & 0.34 & 0.13 & 0.05 & 10.7 & 1.0 & 12.3 & 0.3 \\
\hline 71.336 & 152.095 & 1.0 & $\begin{array}{c}10 / 31 / 18 \\
0: 15 \\
\end{array}$ & 1.93 & 0.17 & 0.02 & 0.02 & 7.3 & 0.4 & 10.7 & 0.1 \\
\hline 71.336 & 152.095 & 63.1 & $\begin{array}{c}10 / 31 / 18 \\
23: 37\end{array}$ & 4.17 & 0.27 & 0.07 & 0.04 & 9.9 & 0.7 & 12.0 & 0.2 \\
\hline 71.463 & 152.002 & 120.2 & $\begin{array}{c}10 / 31 / 18 \\
2: 50\end{array}$ & 2.03 & 0.13 & 0.04 & 0.02 & 9.5 & 0.4 & 13.8 & 0.1 \\
\hline 71.461 & 151.994 & 45.6 & $\begin{array}{c}10 / 31 / 18 \\
3: 44 \\
\end{array}$ & 1.34 & 0.20 & ND & ND & 9.6 & 0.7 & 11.7 & 0.2 \\
\hline 72.663 & 150.879 & 55.2 & $\begin{array}{c}11 / 1 / 18 \\
4: 57 \\
\end{array}$ & 3.13 & 0.17 & 0.05 & 0.03 & 5.8 & 0.4 & 10.5 & 0.1 \\
\hline 70.692 & 148.443 & 20.5 & $\begin{array}{c}11 / 2 / 18 \\
8: 10 \\
\end{array}$ & 5.02 & 0.17 & 0.22 & 0.04 & 9.9 & 0.4 & 12.4 & 0.1 \\
\hline 70.772 & 148.326 & 2.5 & $\begin{array}{c}11 / 2 / 18 \\
9: 20\end{array}$ & 3.47 & 0.15 & 0.09 & 0.03 & 8.3 & 0.5 & 12.2 & 0.1 \\
\hline 70.898 & 148.143 & 36.2 & $\begin{array}{c}11 / 2 / 18 \\
11: 21 \\
\end{array}$ & 6.38 & 0.23 & 0.21 & 0.05 & 9.5 & 0.9 & 12.1 & 0.3 \\
\hline 70.939 & 148.088 & 2.5 & $\begin{array}{c}11 / 2 / 18 \\
12: 07 \\
\end{array}$ & 2.69 & 0.32 & 0.00 & 0.04 & 7.7 & 0.6 & 11.4 & 0.2 \\
\hline 70.978 & 148.038 & 2.5 & $\begin{array}{c}11 / 2 / 18 \\
12: 52\end{array}$ & 1.34 & 0.26 & 0.09 & 0.03 & 8.2 & 1.0 & 11.6 & 0.3 \\
\hline 71.020 & 147.974 & 51.6 & $\begin{array}{c}11 / 2 / 18 \\
13: 36 \\
\end{array}$ & 6.70 & 0.24 & 0.08 & 0.03 & 8.2 & 0.6 & 11.8 & 0.2 \\
\hline 71.147 & 147.803 & 110.4 & $\begin{array}{c}11 / 3 / 18 \\
5: 13 \\
\end{array}$ & 3.33 & 0.21 & ND & ND & 5.8 & 0.4 & 11.7 & 0.1 \\
\hline 71.143 & 147.813 & 60.5 & $\begin{array}{c}11 / 3 / 18 \\
5: 55 \\
\end{array}$ & 1.52 & 0.15 & ND & ND & 7.7 & 0.4 & 11.7 & 0.1 \\
\hline 71.186 & 147.793 & 3.2 & $\begin{array}{c}11 / 3 / 18 \\
7: 39 \\
\end{array}$ & 1.62 & 0.22 & ND & ND & 8.4 & 0.7 & 10.8 & 0.2 \\
\hline 69.817 & 139.610 & 34.1 & $\begin{array}{c}11 / 4 / 18 \\
18: 52\end{array}$ & 11.64 & 0.25 & 0.13 & 0.07 & 7.6 & 0.4 & 12.8 & 0.1 \\
\hline 69.899 & 139.494 & 37.0 & $\begin{array}{c}11 / 4 / 18 \\
20: 42 \\
\end{array}$ & 8.76 & 0.27 & 0.17 & 0.04 & 2.5 & 0.1 & 3.4 & 0.0 \\
\hline 69.940 & 139.387 & 2.5 & $\begin{array}{c}11 / 4 / 18 \\
21: 50\end{array}$ & 1.61 & 0.19 & 0.13 & 0.02 & 12.9 & 0.5 & 22.9 & 0.2 \\
\hline 69.967 & 139.300 & 52.1 & $\begin{array}{c}11 / 4 / 18 \\
23: 00\end{array}$ & 7.00 & 0.36 & 0.16 & 0.08 & 7.3 & 0.8 & 12.2 & 0.2 \\
\hline 70.012 & 139.238 & 2.5 & $\begin{array}{c}11 / 4 / 18 \\
23: 40\end{array}$ & 1.40 & 0.23 & 0.10 & 0.05 & 6.4 & 0.7 & 9.5 & 0.2 \\
\hline 70.056 & 139.213 & 50.3 & $\begin{array}{c}11 / 5 / 18 \\
0: 32\end{array}$ & 2.67 & 0.21 & ND & ND & 7.0 & 0.4 & 11.2 & 0.1 \\
\hline
\end{tabular}




\begin{tabular}{|c|c|c|c|c|c|c|c|c|c|c|c|}
\hline 70.171 & 139.030 & 2.9 & $\begin{array}{c}11 / 5 / 18 \\
2: 40\end{array}$ & 1.45 & 0.24 & ND & ND & 7.9 & 0.4 & 10.4 & 0.1 \\
\hline 69.788 & 139.690 & 2.5 & $\begin{array}{c}11 / 5 / 18 \\
7: 52\end{array}$ & 3.12 & 0.18 & 0.07 & 0.03 & 7.3 & 0.5 & 12.8 & 0.1 \\
\hline 70.201 & 144.033 & 20.3 & $\begin{array}{c}11 / 5 / 18 \\
18: 10\end{array}$ & 6.79 & 0.31 & 0.32 & 0.07 & 9.9 & 0.4 & 14.2 & 0.1 \\
\hline 70.282 & 143.940 & 30.7 & $\begin{array}{c}11 / 5 / 18 \\
19: 22 \\
\end{array}$ & 4.66 & 0.20 & 0.14 & 0.03 & 7.9 & 0.3 & 11.8 & 0.1 \\
\hline 70.373 & 143.792 & 2.5 & $\begin{array}{c}11 / 5 / 18 \\
20: 34 \\
\end{array}$ & 2.86 & 0.37 & 0.03 & 0.04 & 7.8 & 1.1 & 12.3 & 0.3 \\
\hline 70.460 & 143.761 & 43.8 & $\begin{array}{c}11 / 5 / 18 \\
21: 40\end{array}$ & 5.50 & 0.27 & 0.05 & 0.04 & 7.5 & 0.4 & 12.0 & 0.1 \\
\hline 70.557 & 143.624 & 2.5 & $\begin{array}{c}11 / 5 / 18 \\
22: 58\end{array}$ & 1.25 & 0.21 & 0.09 & 0.03 & 10.0 & 0.7 & 11.7 & 0.2 \\
\hline 70.720 & 143.425 & 55.9 & $\begin{array}{c}11 / 6 / 18 \\
2: 00\end{array}$ & 2.48 & 0.26 & 0.09 & 0.04 & 6.7 & 0.3 & 10.8 & 0.1 \\
\hline 70.806 & 143.336 & 2.5 & $\begin{array}{c}11 / 6 / 18 \\
4: 51 \\
\end{array}$ & 1.68 & 0.22 & 0.05 & 0.02 & 7.8 & 0.4 & 11.2 & 0.1 \\
\hline 70.940 & 147.143 & 93.0 & $\begin{array}{c}11 / 7 / 18 \\
6: 12\end{array}$ & 7.23 & 0.25 & 0.10 & 0.04 & 9.1 & 0.4 & 13.1 & 0.1 \\
\hline 70.866 & 147.273 & 44.5 & $\begin{array}{c}11 / 7 / 18 \\
7: 32\end{array}$ & 3.52 & 0.20 & 0.10 & 0.02 & 8.0 & 0.4 & 12.4 & 0.1 \\
\hline 70.781 & 147.336 & 39.4 & $\begin{array}{c}11 / 7 / 18 \\
9: 04\end{array}$ & 9.66 & 0.32 & 0.26 & 0.06 & 8.5 & 0.6 & 12.3 & 0.2 \\
\hline 70.686 & 147.381 & 35.1 & $\begin{array}{c}11 / 7 / 18 \\
10: 30\end{array}$ & 7.27 & 0.25 & 0.16 & 0.03 & 8.9 & 0.3 & 12.0 & 0.1 \\
\hline 70.594 & 147.445 & 29.4 & $\begin{array}{c}11 / 7 / 18 \\
11: 49 \\
\end{array}$ & 4.63 & 0.19 & 0.19 & 0.05 & 8.7 & 0.3 & 12.9 & 0.1 \\
\hline 71.497 & 154.454 & 31.3 & $\begin{array}{c}11 / 9 / 18 \\
1: 39 \\
\end{array}$ & 6.45 & 0.19 & 0.18 & 0.06 & 14.8 & 0.5 & 13.4 & 0.1 \\
\hline 71.559 & 154.495 & 31.5 & $\begin{array}{c}11 / 9 / 18 \\
2: 19\end{array}$ & 4.72 & 0.26 & 0.22 & 0.03 & 14.5 & 0.4 & 12.7 & 0.1 \\
\hline 71.628 & 154.499 & 3.2 & $\begin{array}{c}11 / 9 / 18 \\
3: 03\end{array}$ & 1.58 & 0.16 & 0.12 & 0.03 & 14.7 & 0.6 & 11.8 & 0.1 \\
\hline 71.694 & 154.509 & 44.7 & $\begin{array}{c}11 / 9 / 18 \\
3: 42\end{array}$ & 4.13 & 0.21 & 0.21 & 0.04 & 15.9 & 1.0 & 13.0 & 0.3 \\
\hline 71.829 & 154.526 & 2.6 & $\begin{array}{c}11 / 9 / 18 \\
5: 20\end{array}$ & 2.95 & 0.14 & 0.05 & 0.02 & 11.8 & 0.5 & 11.5 & 0.1 \\
\hline 71.961 & 154.574 & 55.0 & $\begin{array}{c}11 / 9 / 18 \\
7: 03\end{array}$ & 2.04 & 0.15 & 0.11 & 0.02 & 14.0 & 0.7 & 12.6 & 0.2 \\
\hline 72.032 & 154.599 & 3.3 & $\begin{array}{c}11 / 9 / 18 \\
8: 05\end{array}$ & 1.28 & 0.14 & ND & ND & 7.7 & 0.8 & 10.1 & 0.2 \\
\hline 72.096 & 154.592 & 70.0 & $\begin{array}{c}11 / 9 / 18 \\
9: 04 \\
\end{array}$ & 0.98 & 0.16 & 0.04 & 0.02 & 10.8 & 0.9 & 11.7 & 0.2 \\
\hline 71.951 & 156.583 & 67.1 & $\begin{array}{c}11 / 10 / 18 \\
8: 48 \\
\end{array}$ & 5.16 & 0.25 & 0.18 & 0.06 & 15.8 & 0.9 & 15.1 & 0.2 \\
\hline 72.012 & 156.603 & 2.8 & $\begin{array}{c}11 / 10 / 18 \\
9: 33\end{array}$ & 1.84 & 0.14 & 0.02 & 0.02 & 13.8 & 0.4 & 11.2 & 0.1 \\
\hline 72.078 & 156.611 & 68.2 & $\begin{array}{c}11 / 10 / 18 \\
10: 22\end{array}$ & 2.17 & 0.20 & 0.05 & 0.03 & 15.1 & 0.3 & 14.6 & 0.1 \\
\hline 72.146 & 156.609 & 85.5 & $\begin{array}{c}11 / 10 / 18 \\
11: 09 \\
\end{array}$ & 0.60 & 0.14 & ND & ND & 14.7 & 0.4 & 13.9 & 0.1 \\
\hline 72.209 & 156.605 & 3.3 & $\begin{array}{c}11 / 10 / 18 \\
12: 04\end{array}$ & 1.79 & 0.24 & 0.01 & 0.04 & 9.0 & 0.9 & 10.4 & 0.3 \\
\hline
\end{tabular}




\begin{tabular}{|c|c|c|c|c|c|c|c|c|c|c|c|}
\hline 72.285 & 156.629 & 85.5 & $\begin{array}{c}11 / 10 / 18 \\
13: 05 \\
\end{array}$ & 1.30 & 0.14 & 0.05 & 0.02 & 14.0 & 0.5 & 13.9 & 0.1 \\
\hline 72.488 & 156.626 & 120.2 & $\begin{array}{c}11 / 10 / 18 \\
15: 50\end{array}$ & 2.20 & 0.24 & 0.12 & 0.03 & 13.8 & 0.9 & 14.1 & 0.2 \\
\hline 71.013 & 150.873 & 17.2 & $\begin{array}{c}11 / 12 / 18 \\
22: 45\end{array}$ & 10.72 & 0.53 & 0.22 & 0.02 & 10.8 & 0.4 & 13.9 & 0.1 \\
\hline 71.065 & 150.842 & 2.9 & $\begin{array}{c}11 / 12 / 18 \\
23: 26\end{array}$ & 8.66 & 0.34 & 0.35 & 0.06 & 10.8 & 0.5 & 13.1 & 0.1 \\
\hline 71.109 & 150.826 & 23.8 & $\begin{array}{c}11 / 13 / 18 \\
0: 02 \\
\end{array}$ & 5.50 & 0.27 & 0.13 & 0.04 & 10.8 & 1.1 & 12.4 & 0.3 \\
\hline 70.732 & 150.031 & 14.1 & $\begin{array}{c}11 / 13 / 18 \\
6: 09 \\
\end{array}$ & 7.56 & 0.31 & 0.30 & 0.05 & 11.0 & 0.6 & 13.5 & 0.2 \\
\hline 70.776 & 149.993 & 15.3 & $\begin{array}{c}11 / 13 / 18 \\
6: 47\end{array}$ & 4.63 & 0.24 & 0.24 & 0.04 & 11.6 & 0.6 & 12.6 & 0.1 \\
\hline 70.824 & 149.992 & 17.7 & $\begin{array}{c}11 / 13 / 18 \\
7: 45\end{array}$ & 4.81 & 0.19 & 0.20 & 0.03 & 10.8 & 0.3 & 12.8 & 0.1 \\
\hline 70.864 & 149.918 & 4.1 & $\begin{array}{c}11 / 13 / 18 \\
8: 35\end{array}$ & 3.96 & 0.16 & 0.08 & 0.02 & 9.7 & 0.3 & 12.4 & 0.1 \\
\hline 70.910 & 149.889 & 21.0 & $\begin{array}{c}11 / 13 / 18 \\
9: 29\end{array}$ & 4.32 & 0.24 & 0.28 & 0.04 & 9.0 & 0.3 & 12.7 & 0.1 \\
\hline 71.253 & 157.138 & 40.5 & $\begin{array}{c}11 / 14 / 18 \\
8: 43\end{array}$ & 8.63 & 0.25 & 0.01 & 0.01 & 2.7 & 0.2 & 9.4 & 0.1 \\
\hline 71.284 & 157.242 & 2.4 & $\begin{array}{c}11 / 14 / 18 \\
9: 41 \\
\end{array}$ & 3.41 & 0.14 & 0.19 & 0.03 & 11.4 & 0.6 & 11.8 & 0.1 \\
\hline 71.369 & 157.384 & 53.4 & $\begin{array}{c}11 / 14 / 18 \\
11: 38 \\
\end{array}$ & 2.84 & 0.14 & 0.32 & 0.04 & 12.3 & 0.3 & 13.7 & 0.1 \\
\hline 71.460 & 157.591 & 60.0 & $\begin{array}{c}11 / 14 / 18 \\
14: 29\end{array}$ & 3.68 & 0.18 & 0.05 & 0.03 & 9.7 & 0.2 & 13.4 & 0.0 \\
\hline 71.537 & 157.754 & 3.4 & $\begin{array}{c}11 / 14 / 18 \\
16: 11 \\
\end{array}$ & 1.18 & 0.13 & 0.07 & 0.02 & 12.9 & 0.2 & 11.0 & 0.0 \\
\hline 71.580 & 157.833 & 59.1 & $\begin{array}{c}11 / 14 / 18 \\
16: 51\end{array}$ & 4.94 & 0.33 & 0.19 & 0.05 & 17.1 & 0.8 & 15.3 & 0.2 \\
\hline 71.622 & 157.928 & 57.1 & $\begin{array}{c}11 / 14 / 18 \\
18: 13\end{array}$ & 6.57 & 0.25 & 0.29 & 0.03 & 13.1 & 0.9 & 12.0 & 0.2 \\
\hline 68.247 & 167.128 & 39.0 & $\begin{array}{c}11 / 15 / 18 \\
14: 40\end{array}$ & 10.11 & 0.28 & 0.31 & 0.04 & 18.4 & 0.6 & 16.0 & 0.1 \\
\hline 68.013 & 167.877 & 2.8 & $\begin{array}{c}11 / 15 / 18 \\
17: 44\end{array}$ & 2.97 & 0.15 & 0.25 & 0.04 & 14.1 & 0.5 & 12.5 & 0.1 \\
\hline 67.783 & 168.589 & 45.5 & $\begin{array}{c}11 / 15 / 18 \\
21: 25 \\
\end{array}$ & 7.00 & 0.22 & 0.55 & 0.07 & 13.9 & 0.5 & 14.9 & 0.1 \\
\hline
\end{tabular}




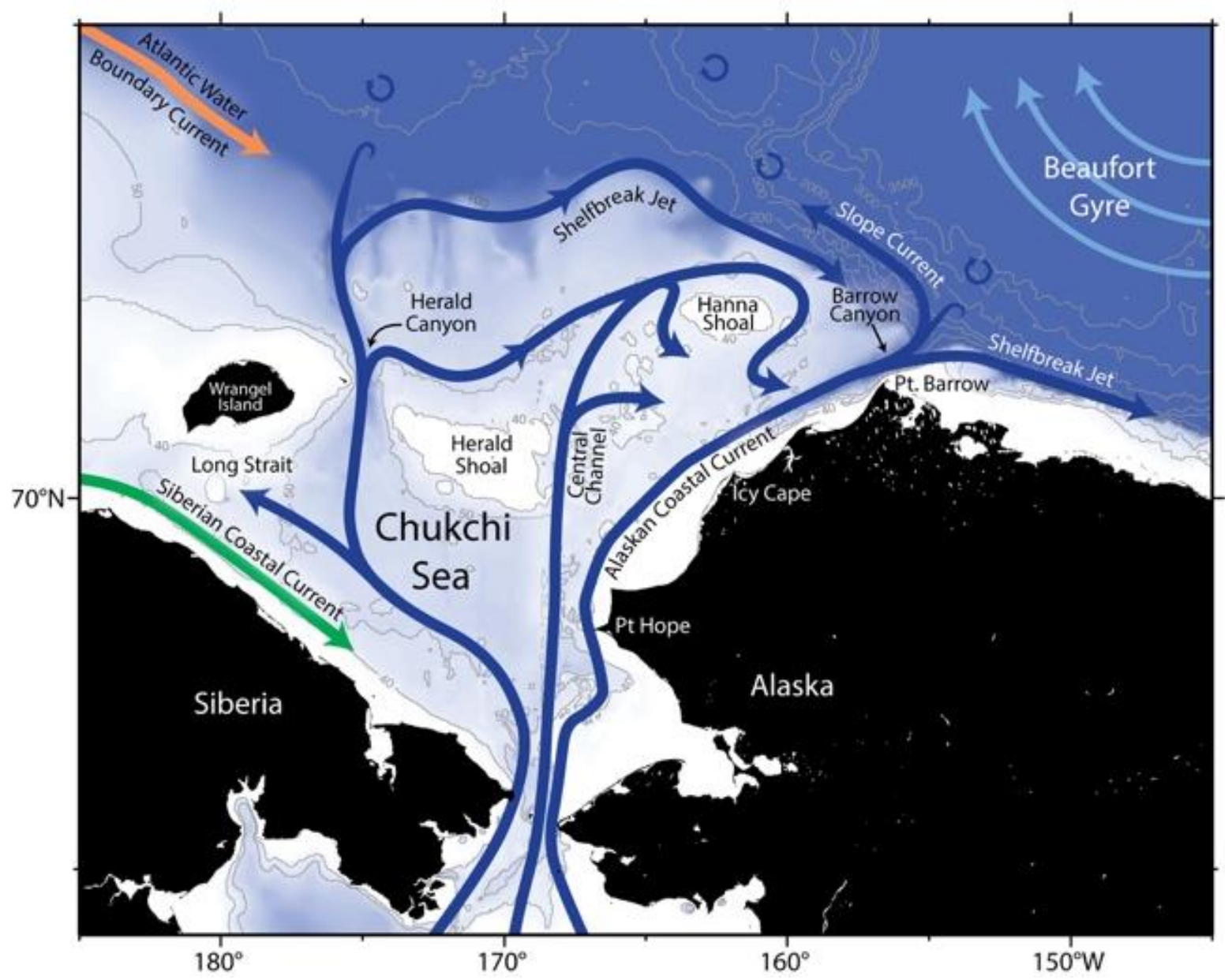

Figure 1 Schematic circulation of the Chukchi and western Beaufort seas, with place names. 
A)

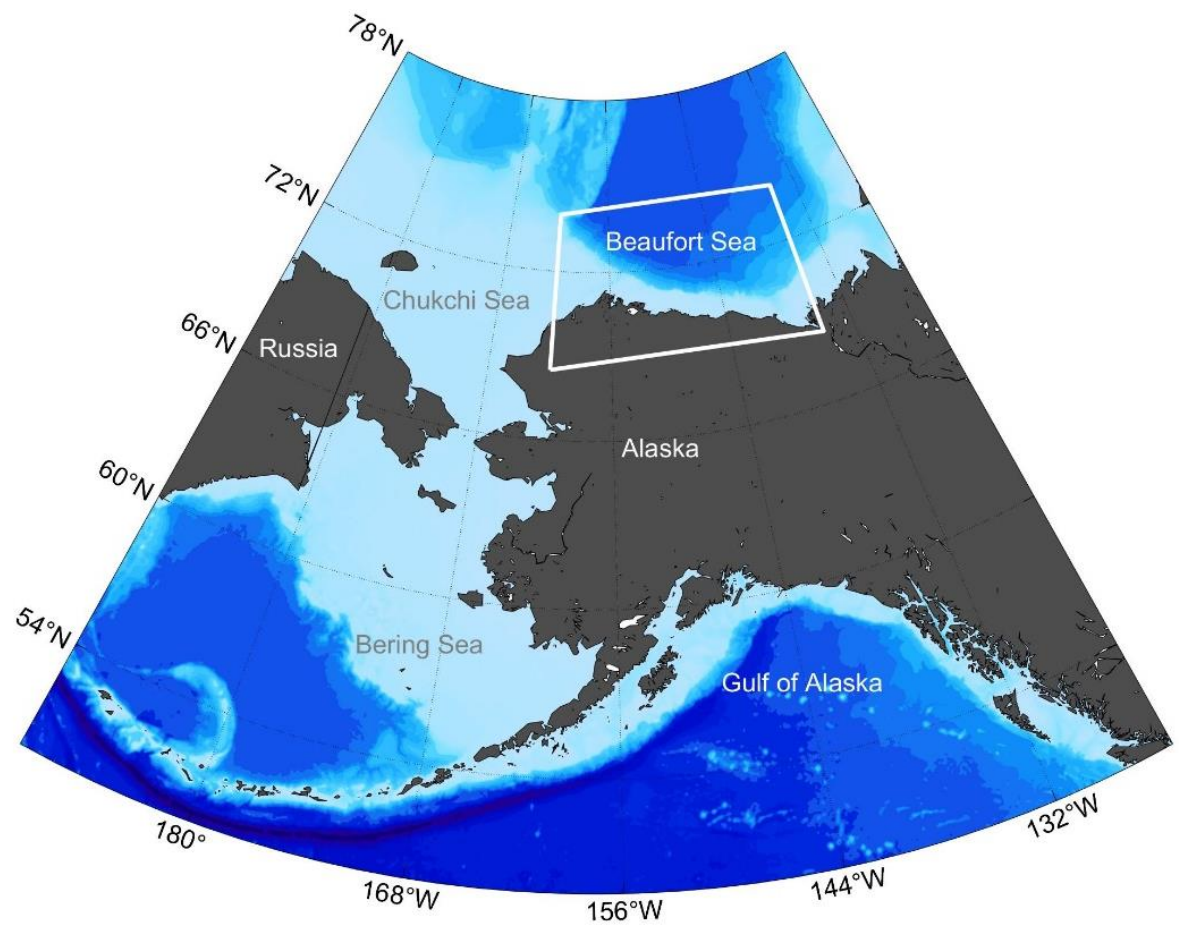

B)

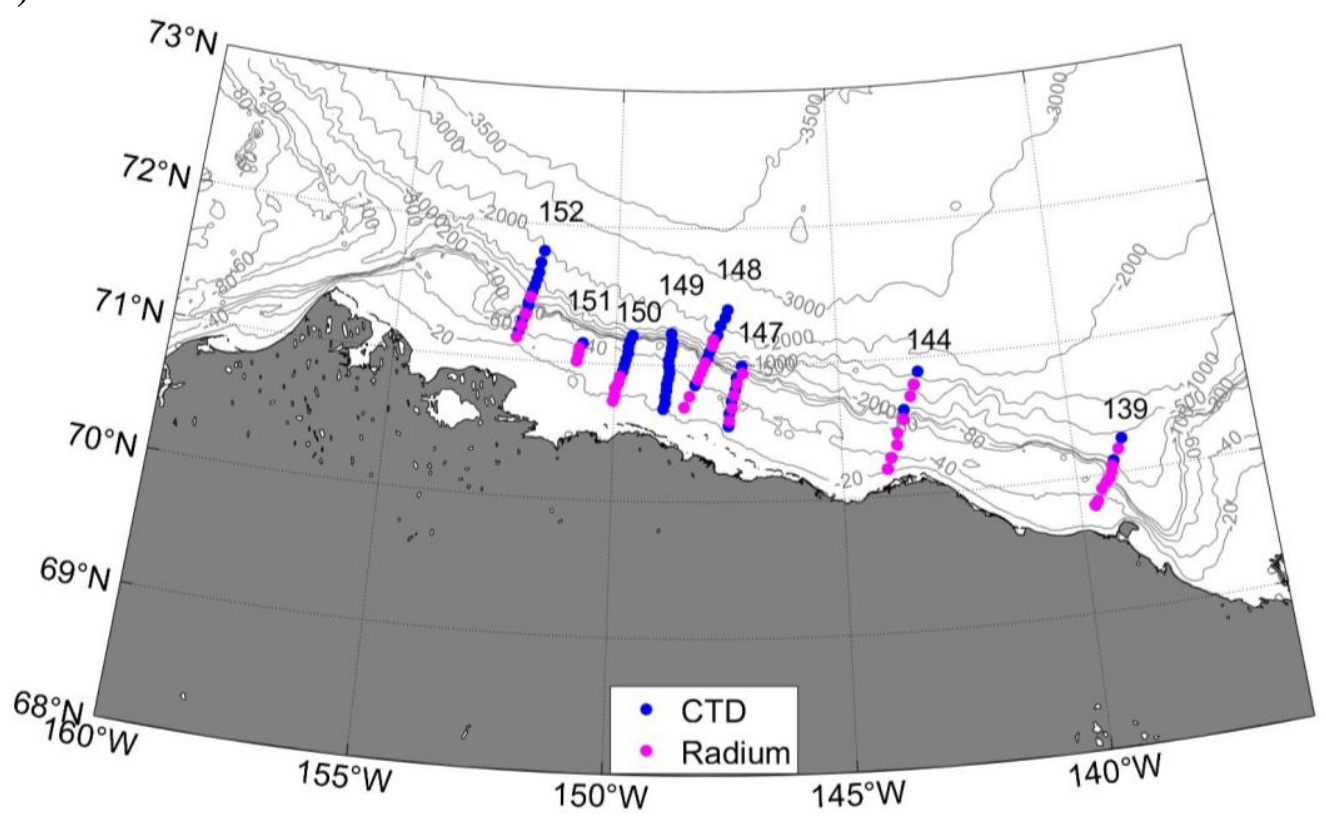

Figure 2 (a) Map of study area with place names. The sampling area is highlighted in a white box. (b) Locations of sampling stations during HLY1803, Oct - Nov 2018. Conductivitytemperature-depth (CTD) stations are shown in blue. CTD/Radium stations are shown in magenta. The sections are labeled by their approximate longitude. 
A)

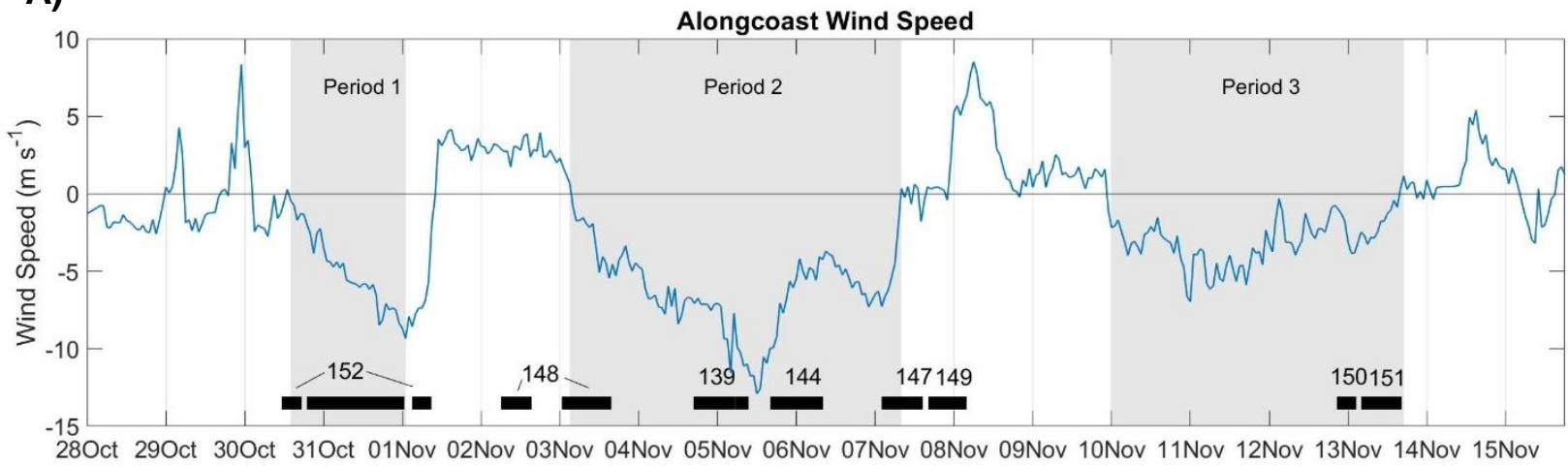

B)

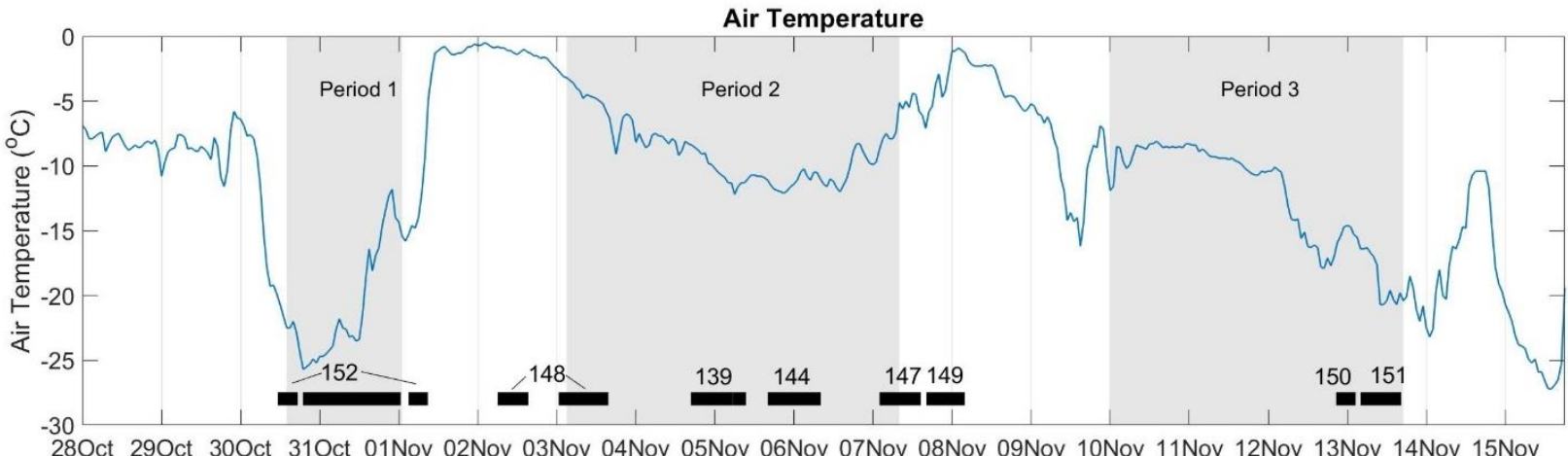

Day \& Month of 2018

Figure 3 (a) Alongcoast wind from the Barrow Atmospheric Baseline Observatory (blue) and ERA5 reanalysis (orange). The grey shading indicates the three upwelling events. The black bars at the bottom mark the time of occupation of the hydrographic sections (labeled by longitude). (b) Air-temperature at 2-m above sea level measured at the Barrow Atmospheric Baseline Observatory. 

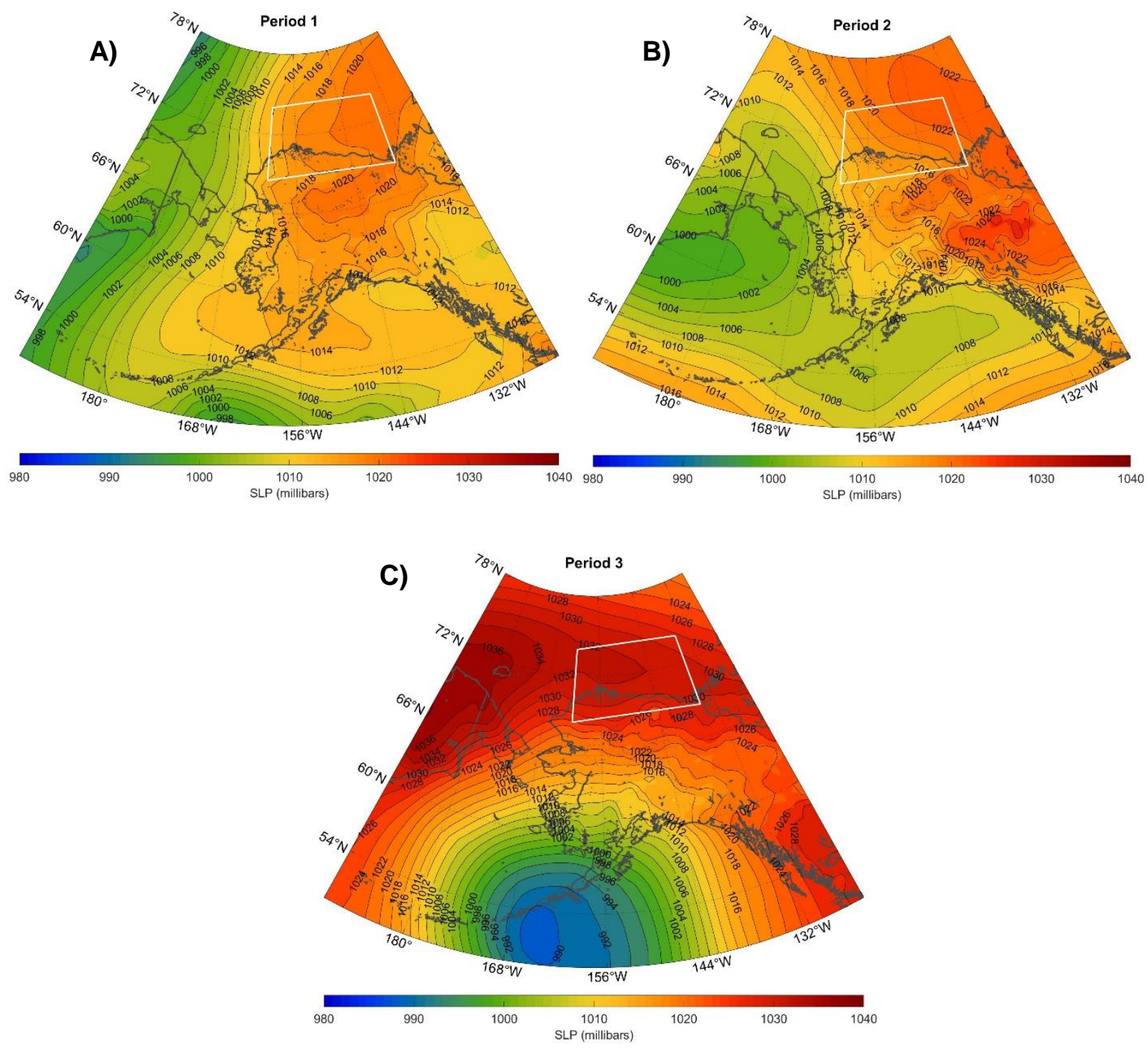

Figure 4 Composite maps of sea level pressure (colors and contours) for the three periods considered in the study. Coastlines are outlined in light grey. The study area is shown in a white box. This study area's composite wind vectors are shown in Figure 5. 

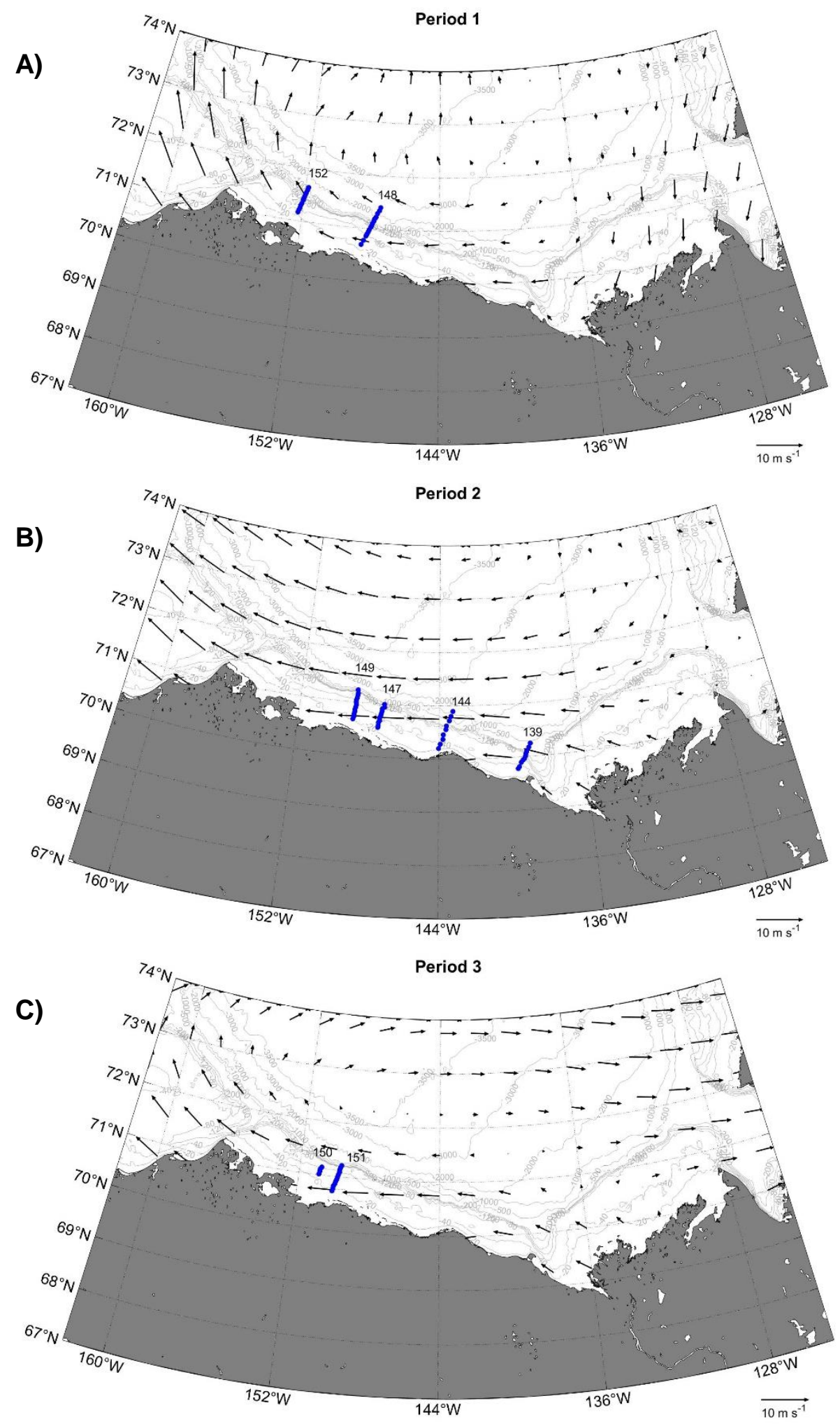

Figure 5 Composite vector maps of the 10-m wind for the three periods. The wind vectors are shown as black arrows. CTD stations are shown in blue and labeled by approximate longitude. Period 1 includes section 148, sampled post-period 1. 
A)

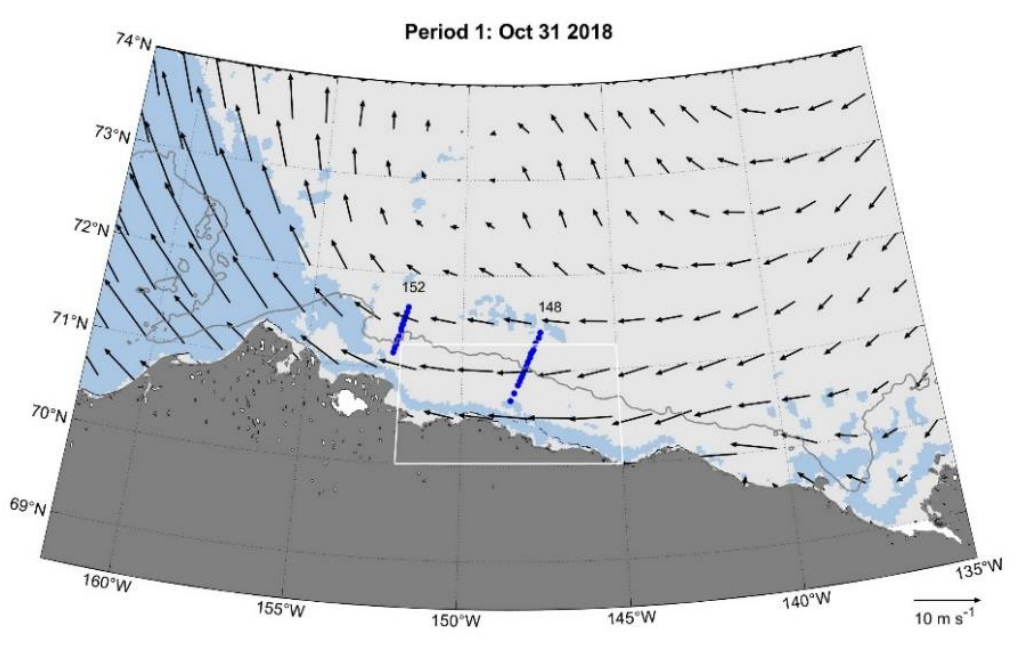

B)
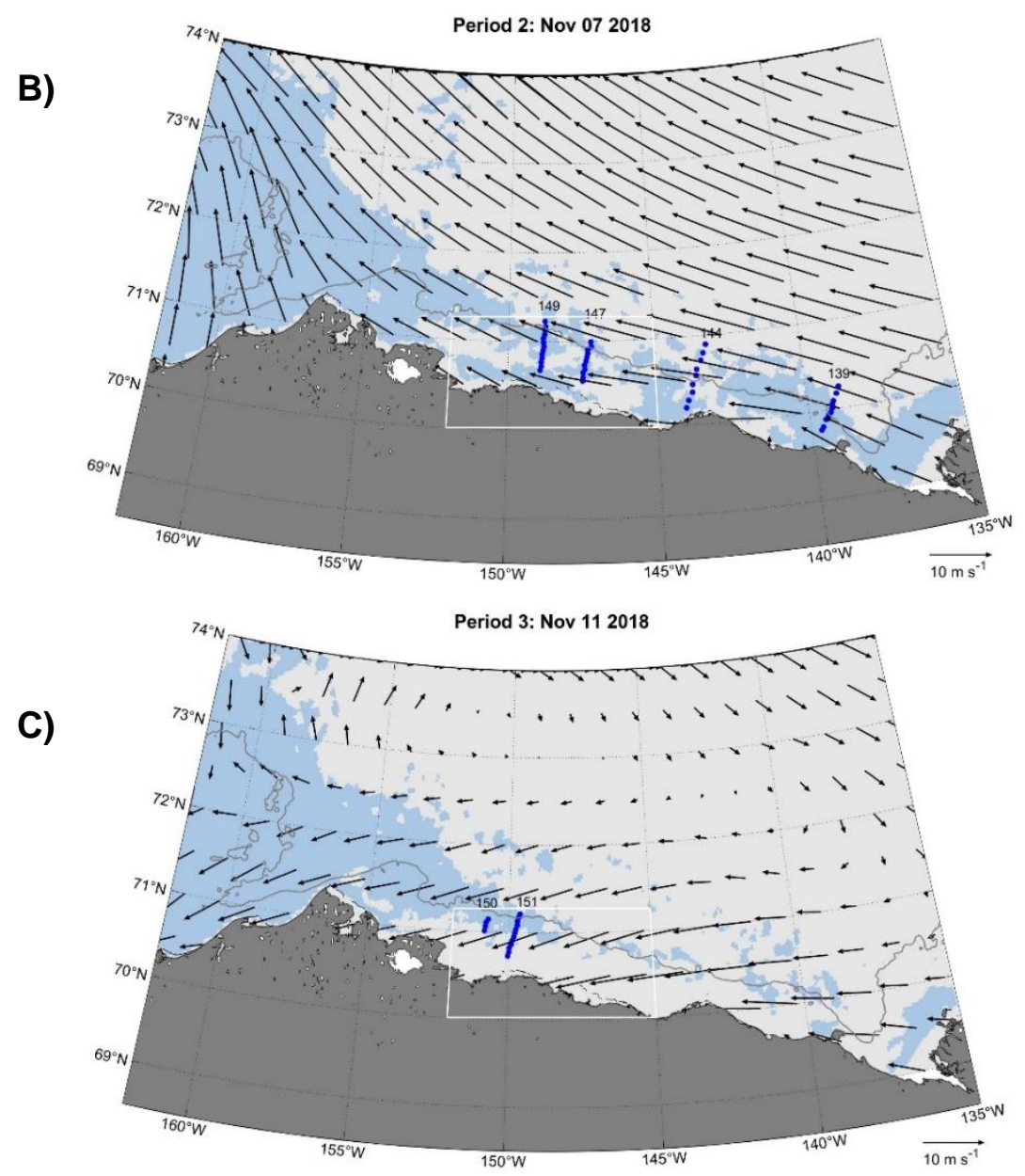

Figure 6 Snapshots showing regions where polynyas were present (ice concentration $<80 \%$, light blue shading). (a) 1 Nov, during event \#1. (b) 7 Nov, during event \#2. (c) 12 Nov during event \#3. The light grey shading corresponds to ice concentration $>80 \%$, and the vectors show the mean winds over the 24-hr period. The hydrographic stations occupied during or just following each of the events are displayed as blue dots, labeled by longitude. The 60-m isobath shows the shelf-edge in gray. A white box shows the area where ice concentrations are averaged and presented in Figure 13. 


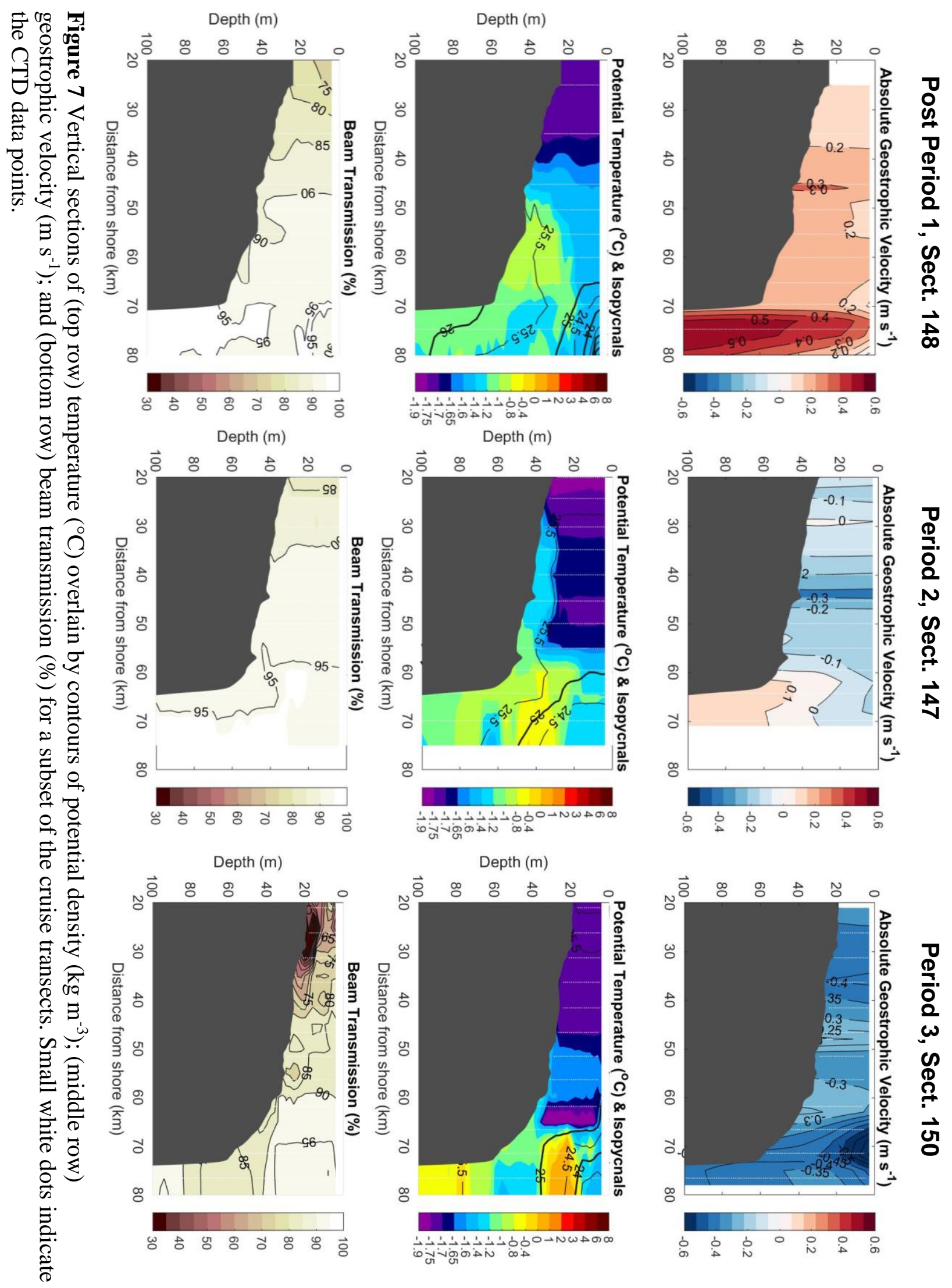



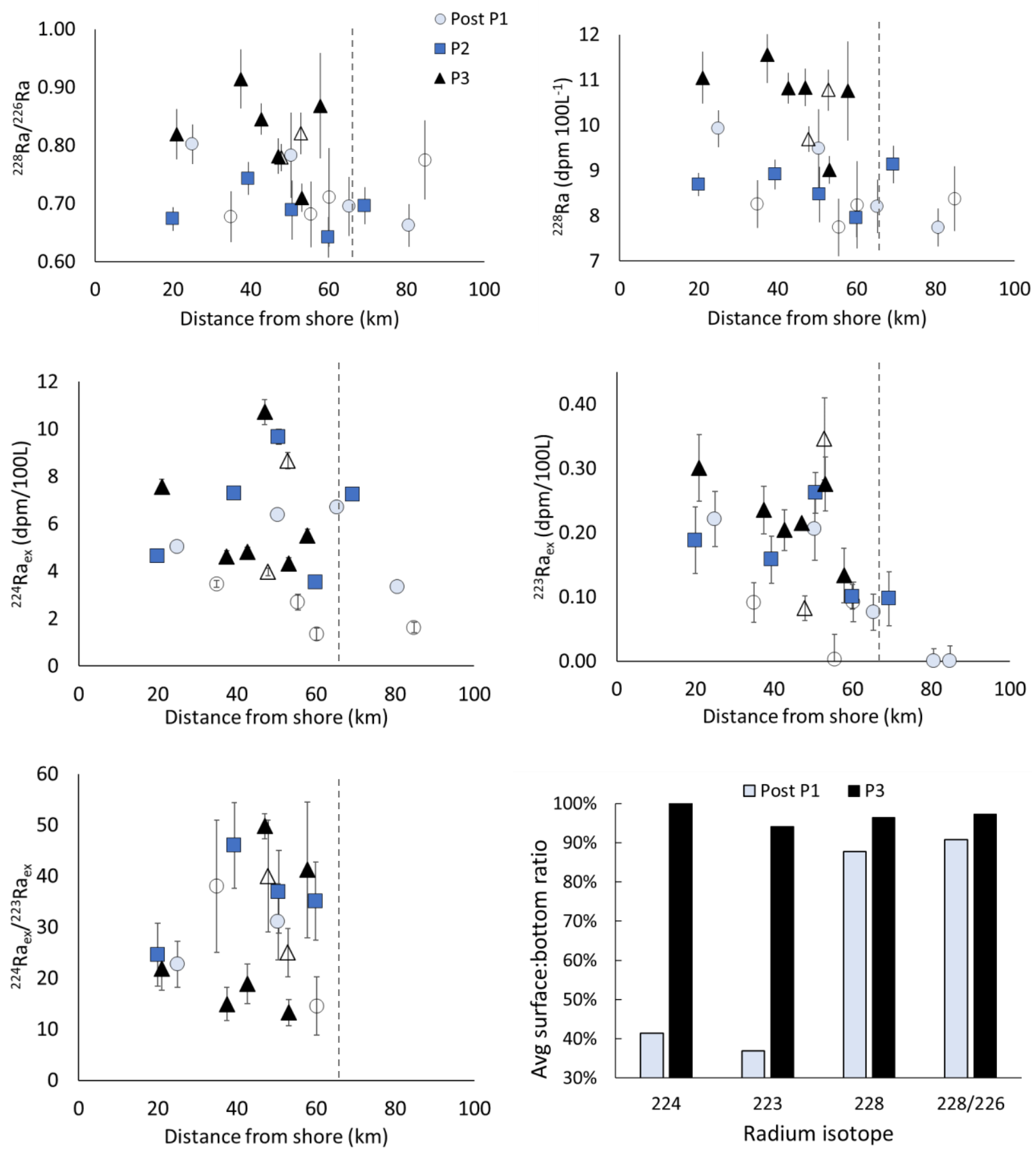

Figure 8 Radium isotopes on the Beaufort shelf and slope. light blue circles, blue squares and black triangles represent sampling during post-period 1, period 2 and period 3 (Nov 2-3, Nov 7 , Nov 12-13), respectively. Samples with undetectable ${ }^{223} \mathrm{Ra}_{\mathrm{ex}}$ are excluded from the ${ }^{224} \mathrm{Ra}_{\mathrm{ex}}{ }^{223} \mathrm{Ra}_{\mathrm{ex}}$ plot. The bottom right panel shows the average surface to bottom water ratio of each radium isotope. Filled symbols are bottom water samples. Open symbols are surface samples. The dashed grey line denotes the location of the shelfbreak. 


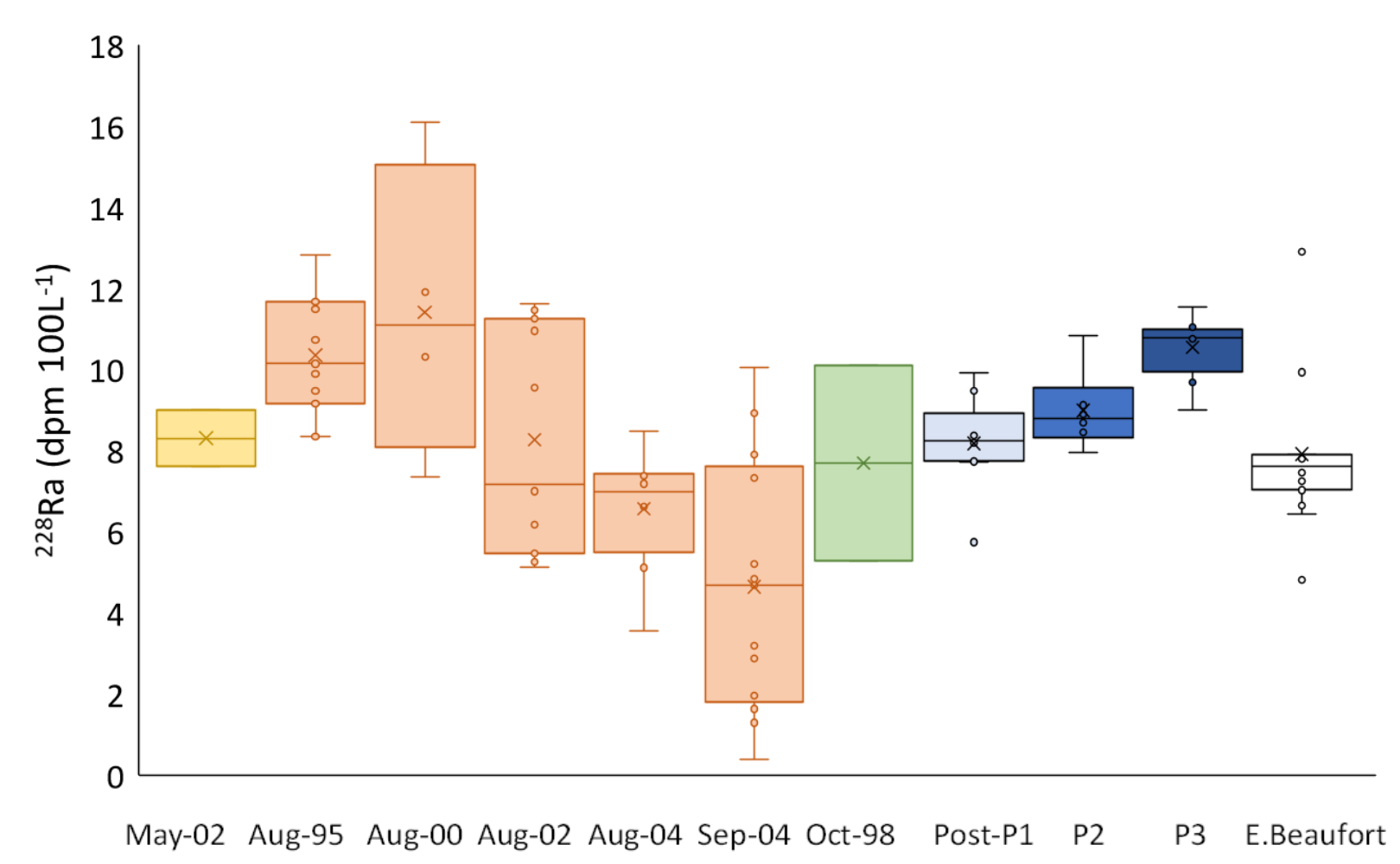

Figure 9 Samples from this study compared to previous studies near the Alaskan \& Canadian Beaufort Shelves. Historical samples are limited to $69-72^{\circ} \mathrm{N}$ and depths of $0-75 \mathrm{~m}$ for the closest comparison to this study (Kadko et al., 2008; Kadko \& Muench, 2005; Kipp et al., 2019; Smith et al., 2003; Trimble et al., 2004). For samples in the Beaufort Sea, only samples east of the Barrow Canyon are shown. Historical samples are colored by season (yellow $=$ spring, orange $=$ summer, green $=$ autumn $)$. Post Period $1($ Nov 2-3), Period $2($ Nov 7), and Period $3($ Nov 12-13) are colored in light, medium and dark blue, respectively. Samples from the Eastern Beaufort shelf samples during Period 2 of this study are shown in white. 

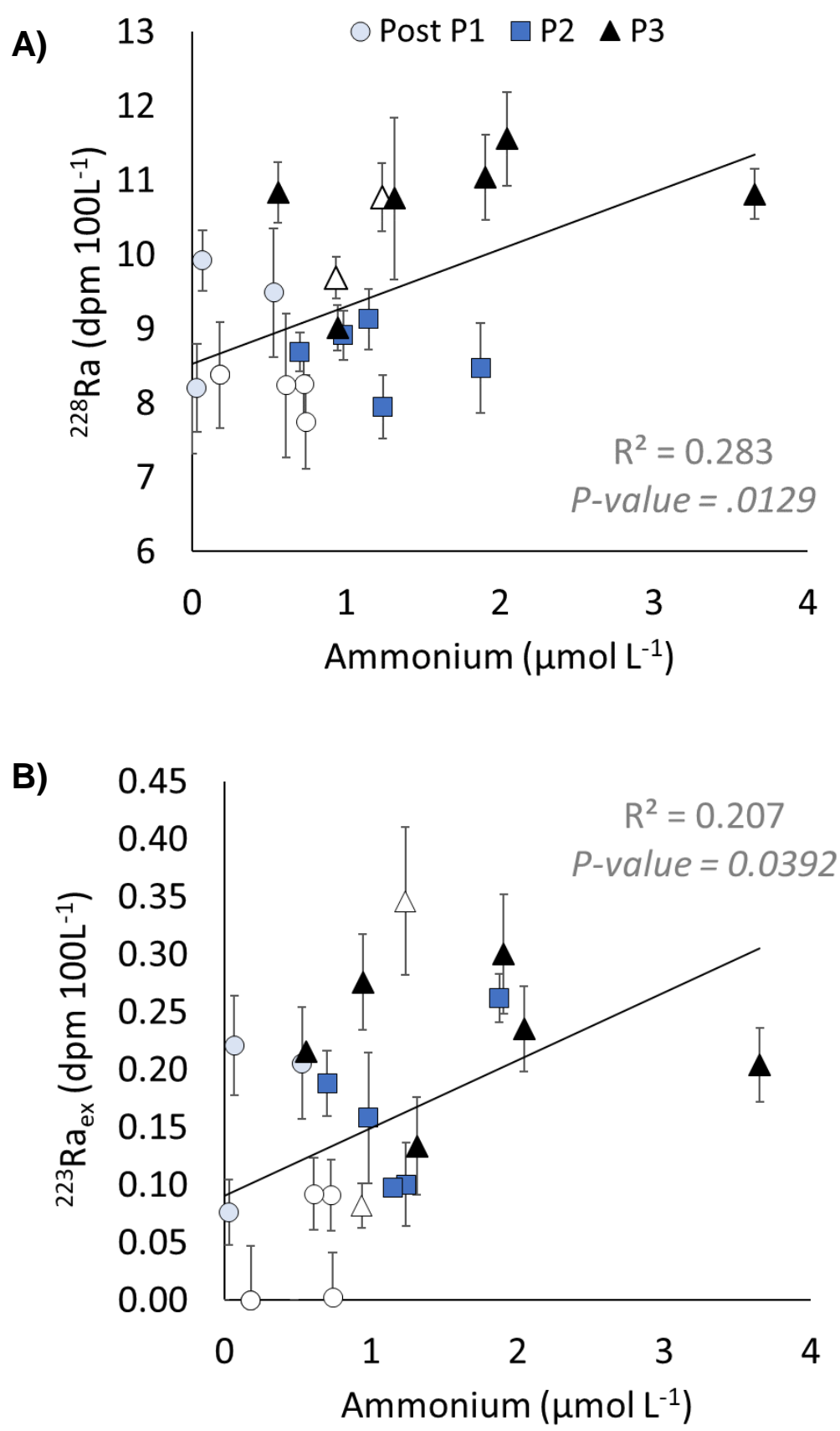

Figure 10 (a) ${ }^{228} \mathrm{Ra}$ and (b) ${ }^{223} \mathrm{Ra}_{\mathrm{ex}}$ plotted with respect to ammonium concentrations. Post Period 1 (Nov 2-3), Period 2 (Nov 7), and Period 3 (Nov 12-13) are shown in circle, square and triangle symbols, respectively. Filled symbols are bottom waters and unfilled symbols are surface waters. The regression parameters are shown in gray text for the best linear fit to all the data (black line). 


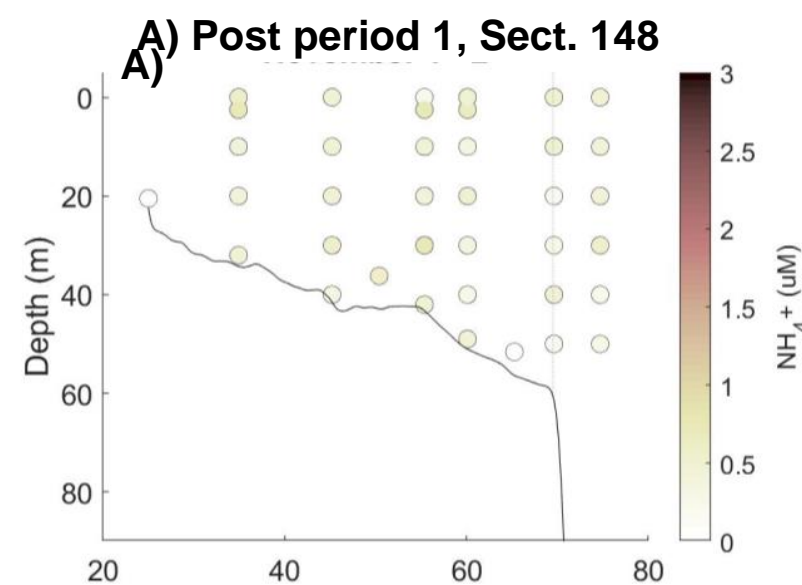

B) Distance $(\mathrm{km})$

C) Period 3, Sect. 150-151

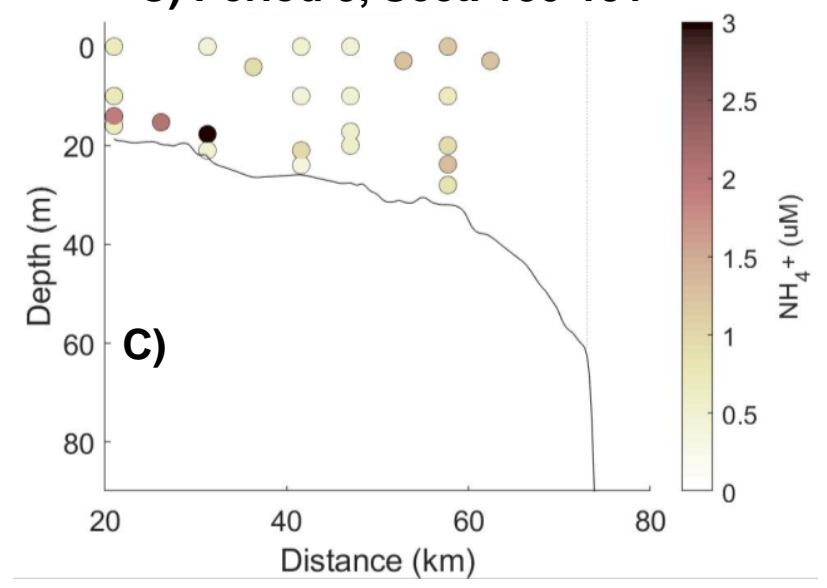

B) Period 2, Sect. 147

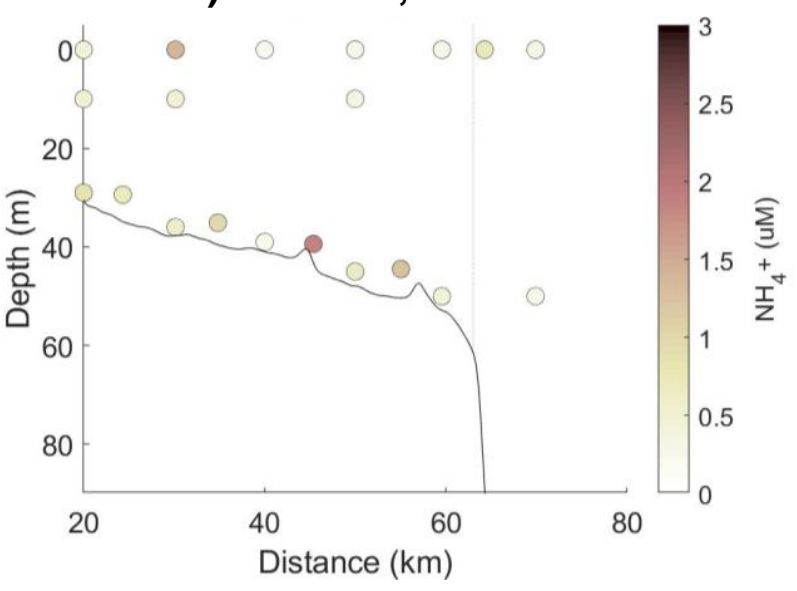

Figure 11 Ammonium concentrations in the central Beaufort Sea during Post-period 1 (Nov 23), Period 2 (Nov 7), and Period 3 (Nov 12-13). In panels a-c, the black line shows the bathymetry. The gray dashed line marks the approximate shelf edge.

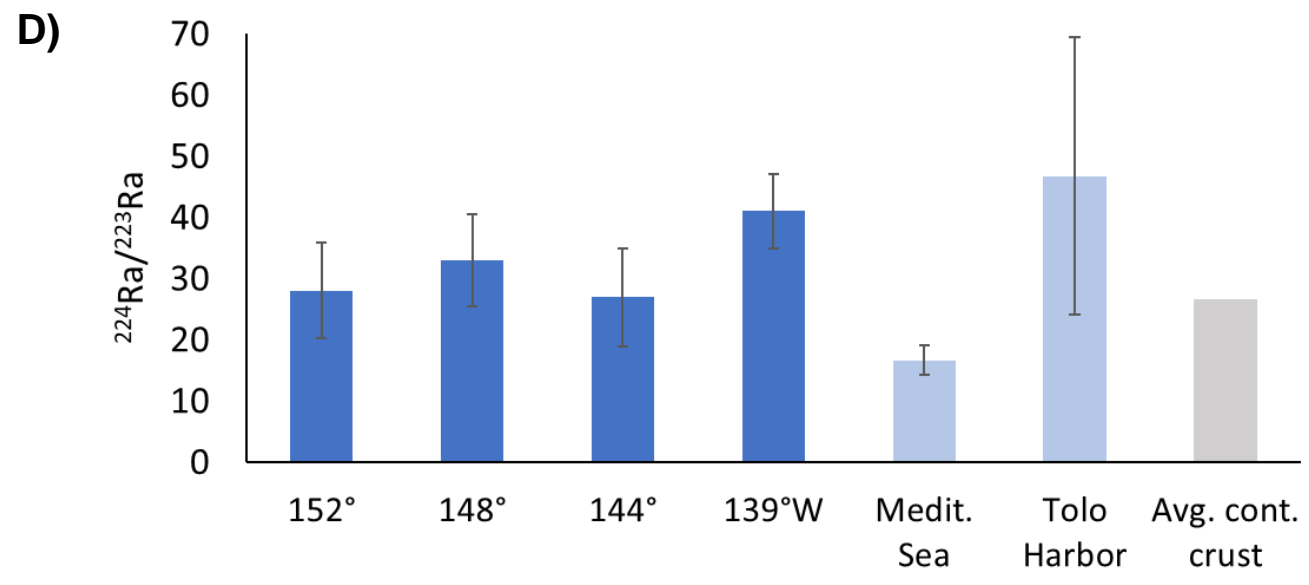



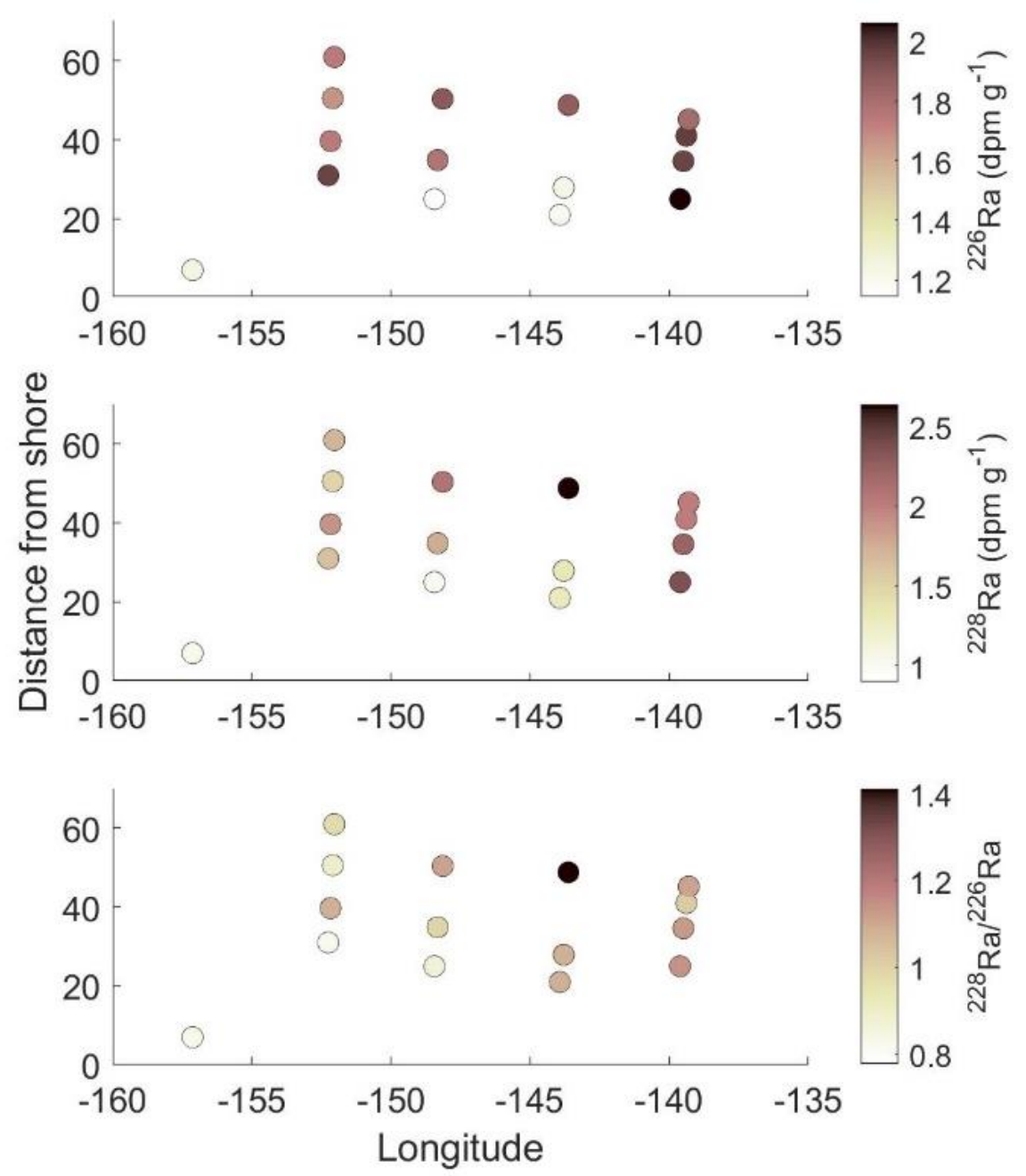

Figure 12 Radium isotopes in Beaufort Sea shelf sediments. Panel (a) shows surface available activity ratios of ${ }^{224} \mathrm{Ra} /{ }^{223} \mathrm{Ra}$. In light blue are values from Tamborski et al. (2019) and Liu et al. (2018), and in gray is the average value for continental crust. Panels b-d are bulk sediment radium activities measured via gamma spectrometry. 


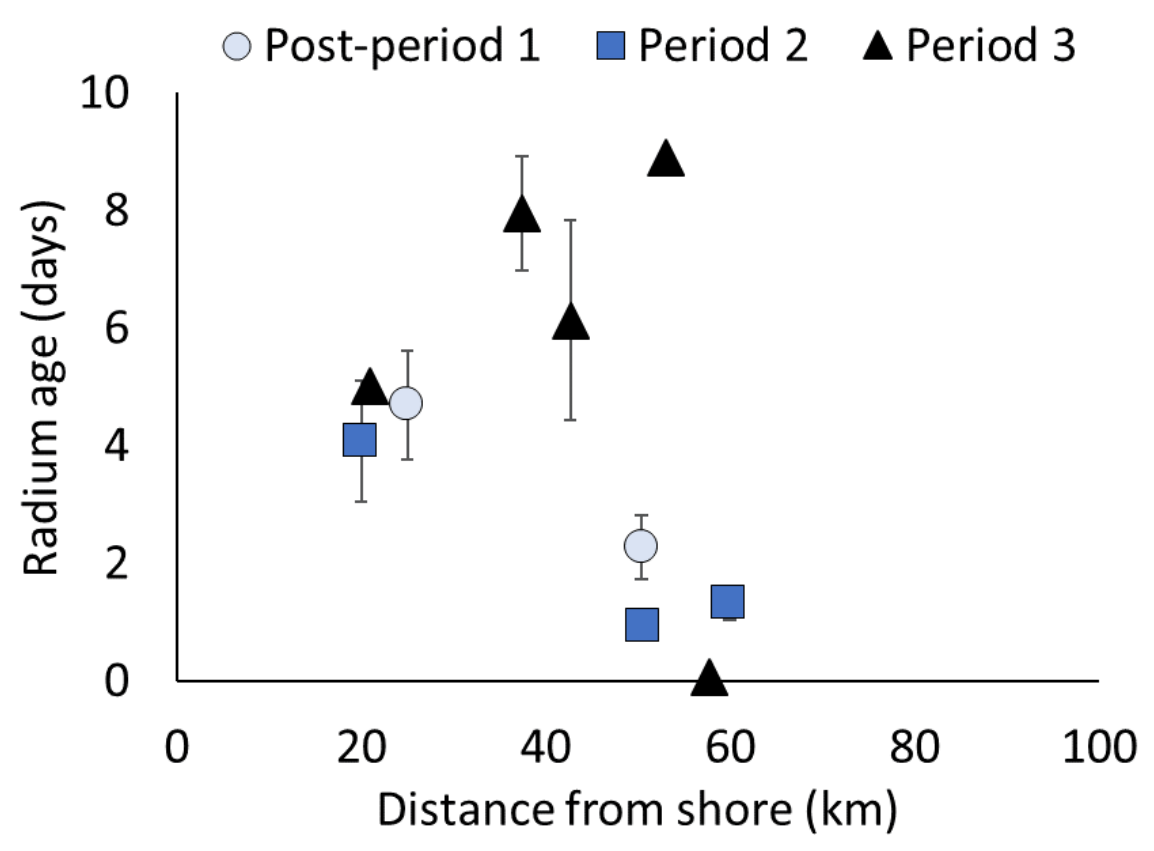

Figure 13 Radium ages of bottom waters (time since sediment-water interaction) in the central Beaufort Sea. Ages were calculated using bottom water ${ }^{224} \mathrm{Ra}_{\mathrm{ex}} / 223 \mathrm{Ra}_{\mathrm{ex}}$ activity ratios. Post Period 1 (Nov 2-3), Period 2 (Nov 7), and Period 3 (Nov 12-13) are shown in circle, square and triangle symbols, respectively. 
A)

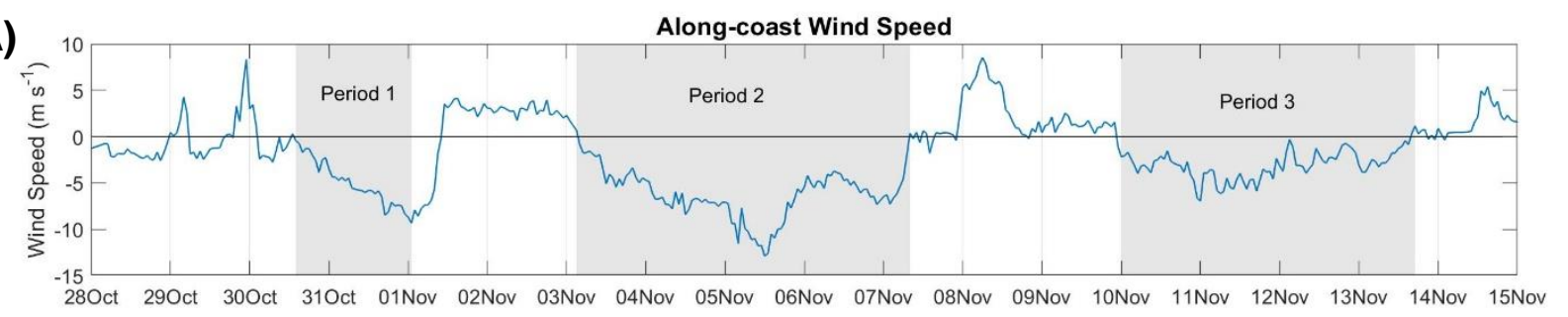

B)
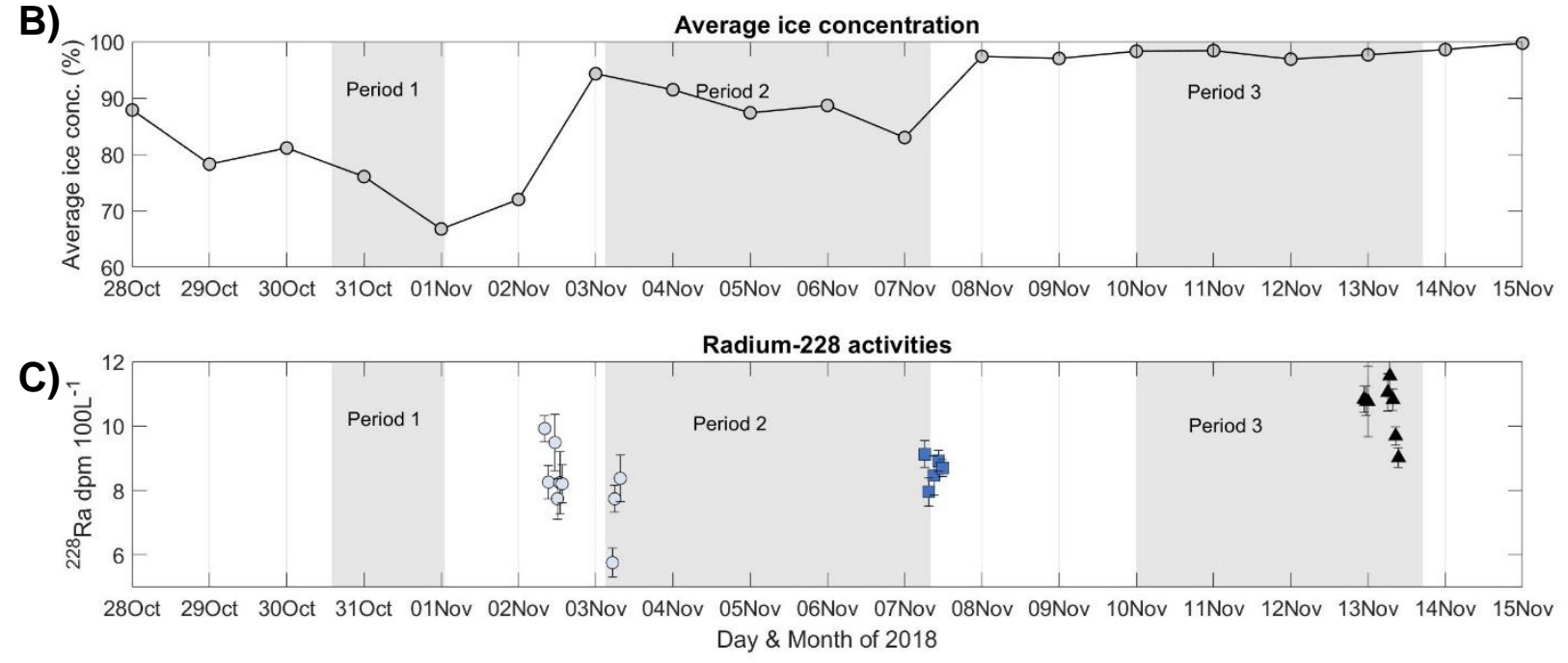

Figure 14 Wind speeds, ice concentrations and radium-228 activities. (a) Alongcoast wind speed from the Barrow Atmospheric Baseline Observatory. (b) Average sea ice concentrations calculated using AMSR-2 data on the central Beaufort shelf $\left(70-71.25^{\circ} \mathrm{N}, 145-152^{\circ} \mathrm{W}\right.$, marked on Figure 6). (c) ${ }^{228} \mathrm{Ra}$ activities measured on the central Beaufort shelf after period 1 (circles), at the end of period 2 (squares), and near the end of period 3 (triangles). 

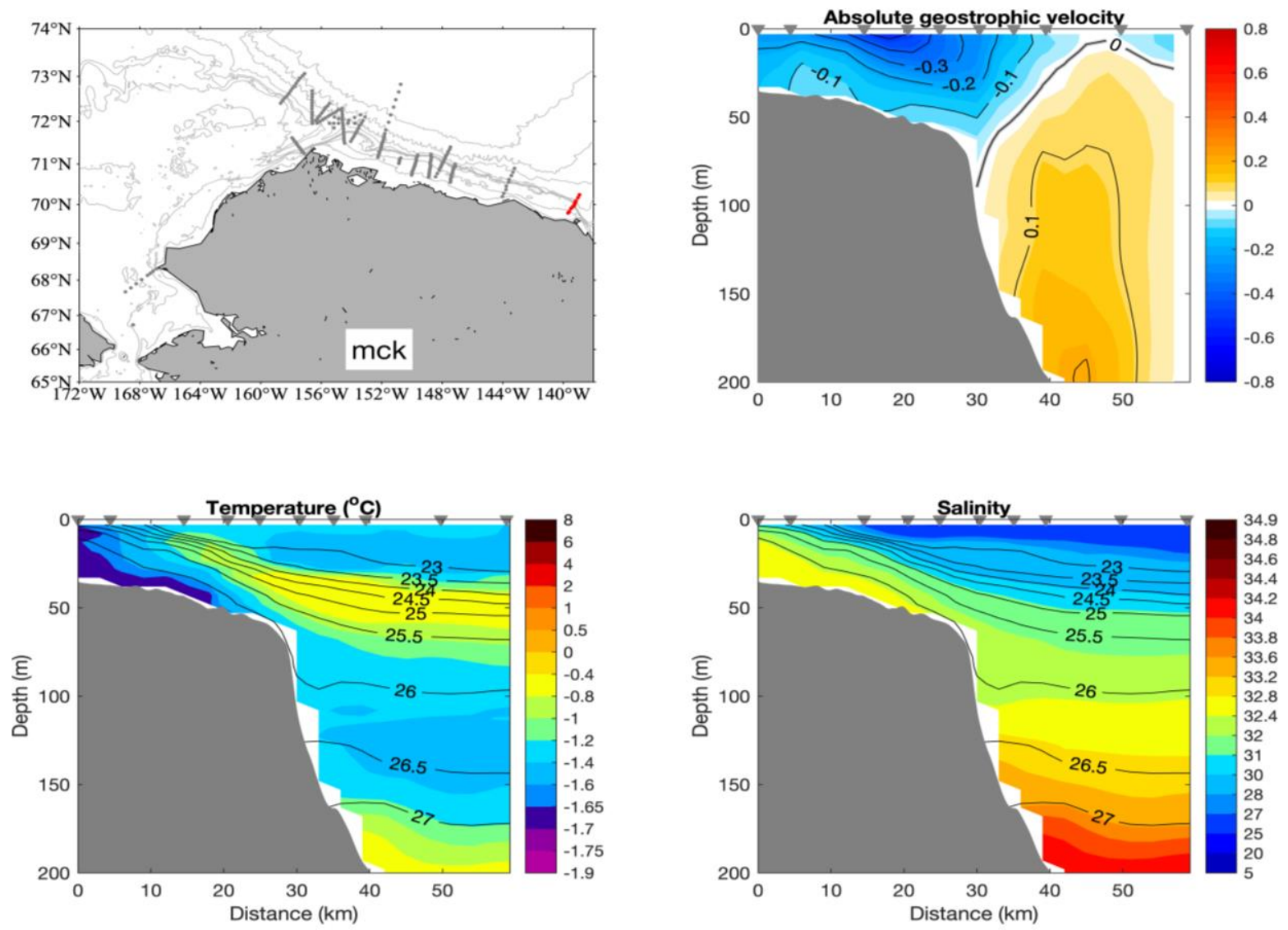

Figure S1 Hydrographic data in the Eastern Beaufort Sea at $139^{\circ} \mathrm{W}$ on Nov 5, 2018. The section is highlighted on the map in the upper left panel in red. The top right panel shows geostrophic velocity with contours. In the bottom left panel is temperature with density contour lines. In the bottom right panel, salinity is overlain with density contours. 

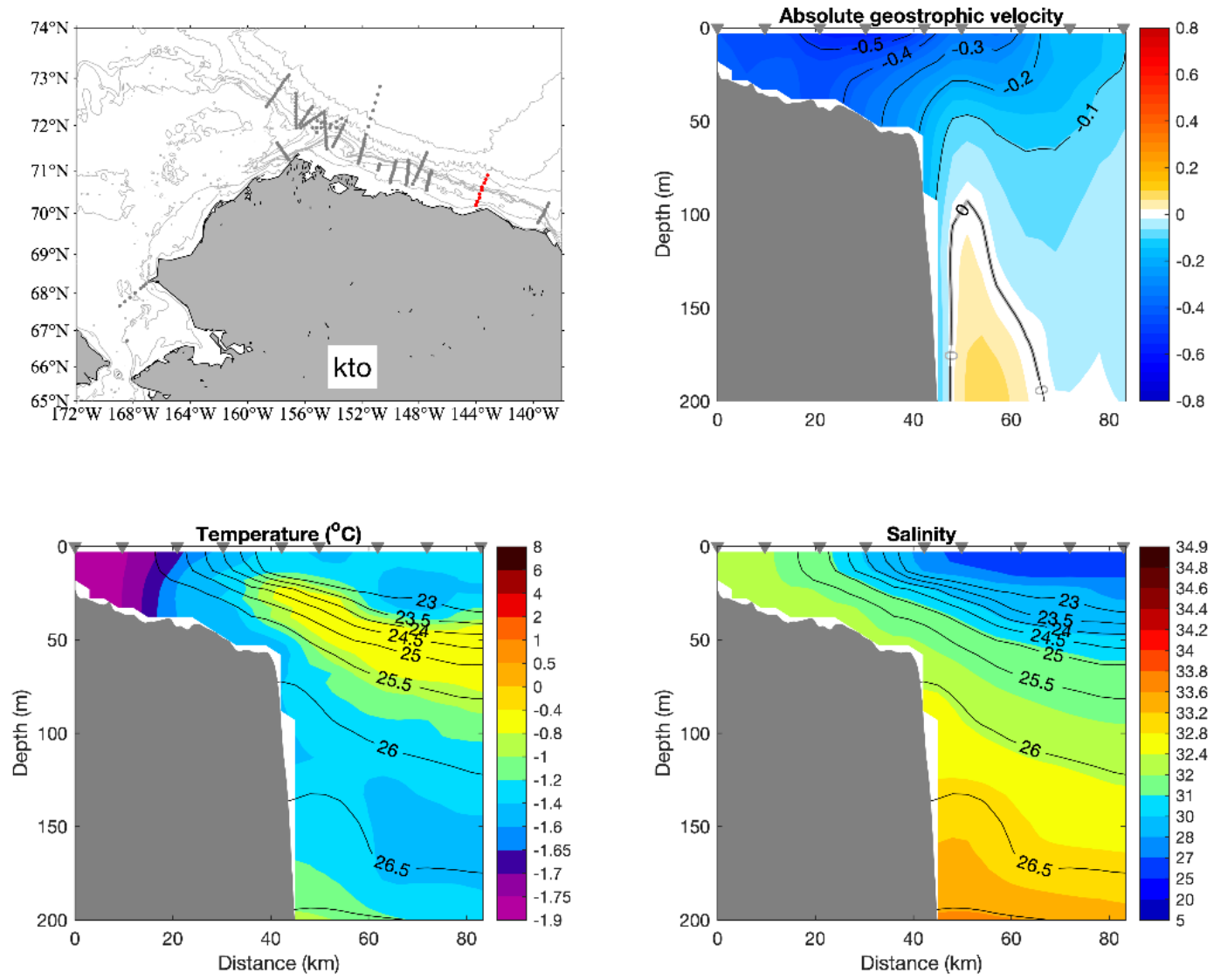

Figure S2 Hydrographic data in the Eastern Beaufort Sea at $144^{\circ} \mathrm{W}$ on Nov 4-5, 2018. The section is highlighted on the map in the upper left panel in red. The top right panel shows geostrophic velocity with contours. In the bottom left panel is temperature with density contour lines. In the bottom right panel, salinity is overlain with density contours. 


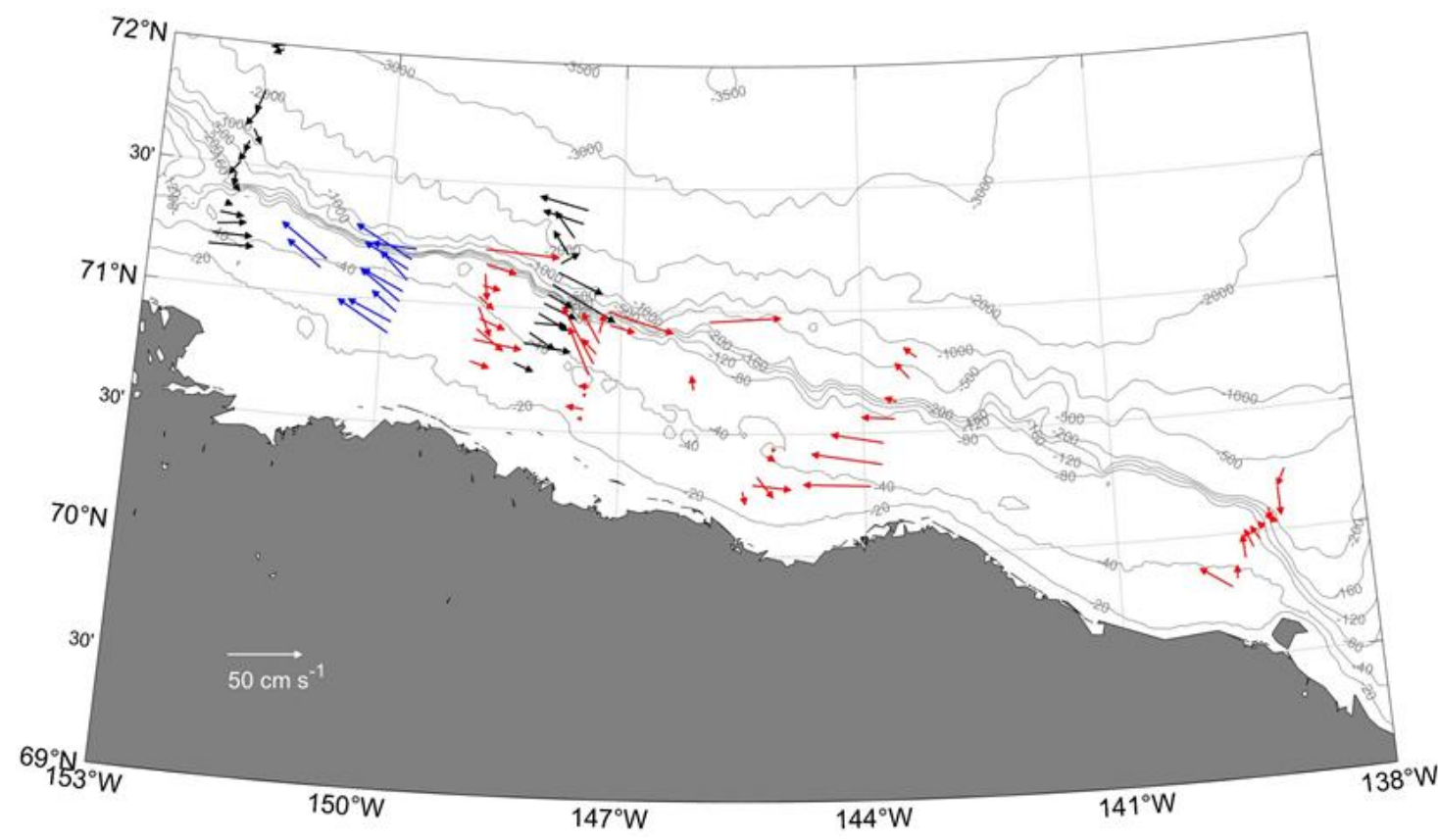

Figure S3 Depth-averaged (18-100 m) velocity vectors from the shipboard acoustic Doppler current profiler. Samples collected during Oct 30-Nov 3 are shown in black arrows. Red arrows show sampling on Nov 4-8. Blue arrows show sampling on Nov 12-13. A white arrow Is shown in the bottom left shown for scale. 

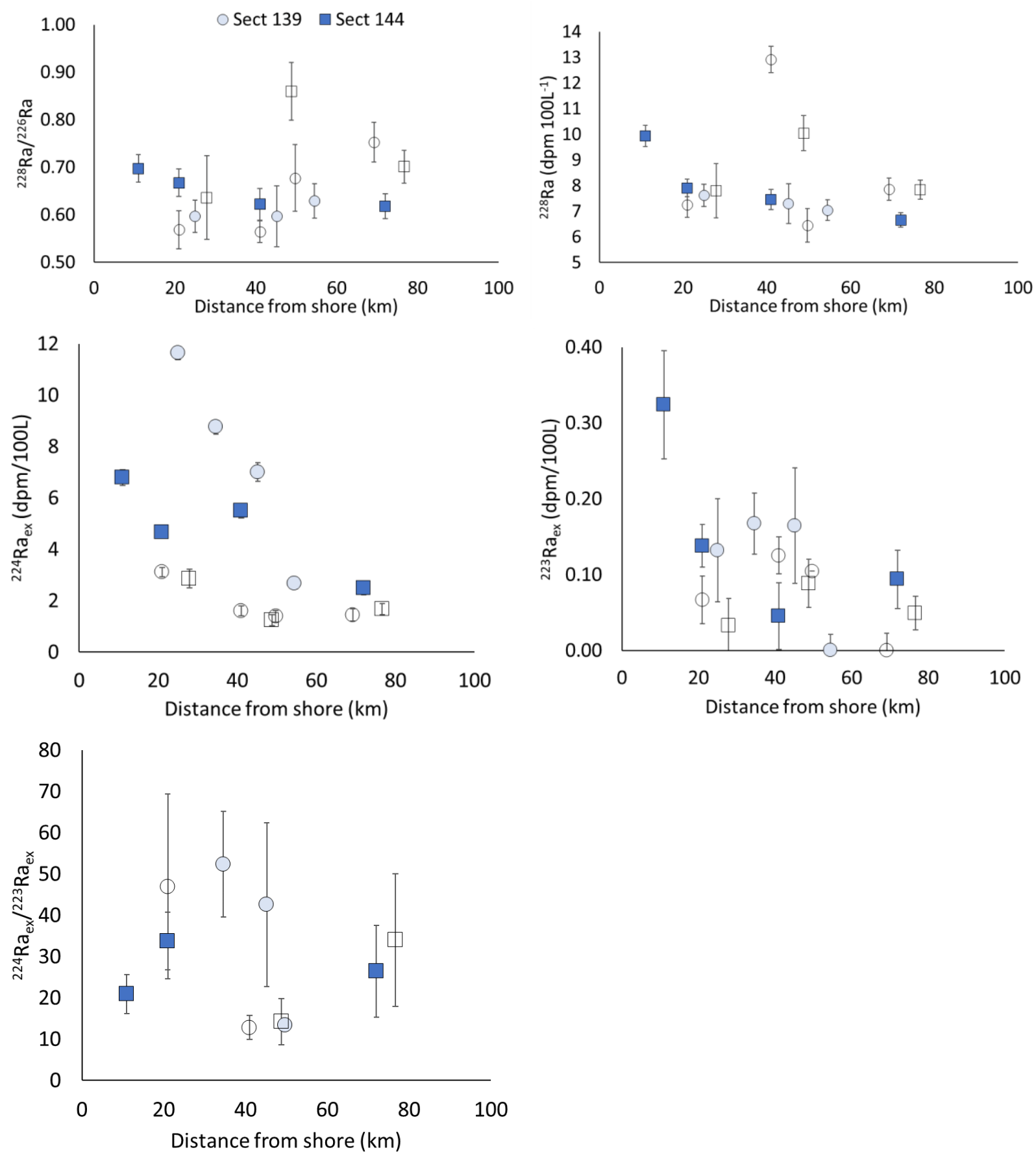

Figure S4 Radium isotopes in the eastern Beaufort Sea during Period 2, on Nov 4-5 ${ }^{\text {th }}, 2018$. Circles are samples from the transect at $\sim 139^{\circ} \mathrm{W}$, and squares represented the transect at $144^{\circ} \mathrm{W}$. Filled symbols are bottom water samples and slope samples. Unfilled symbols are surface samples. 


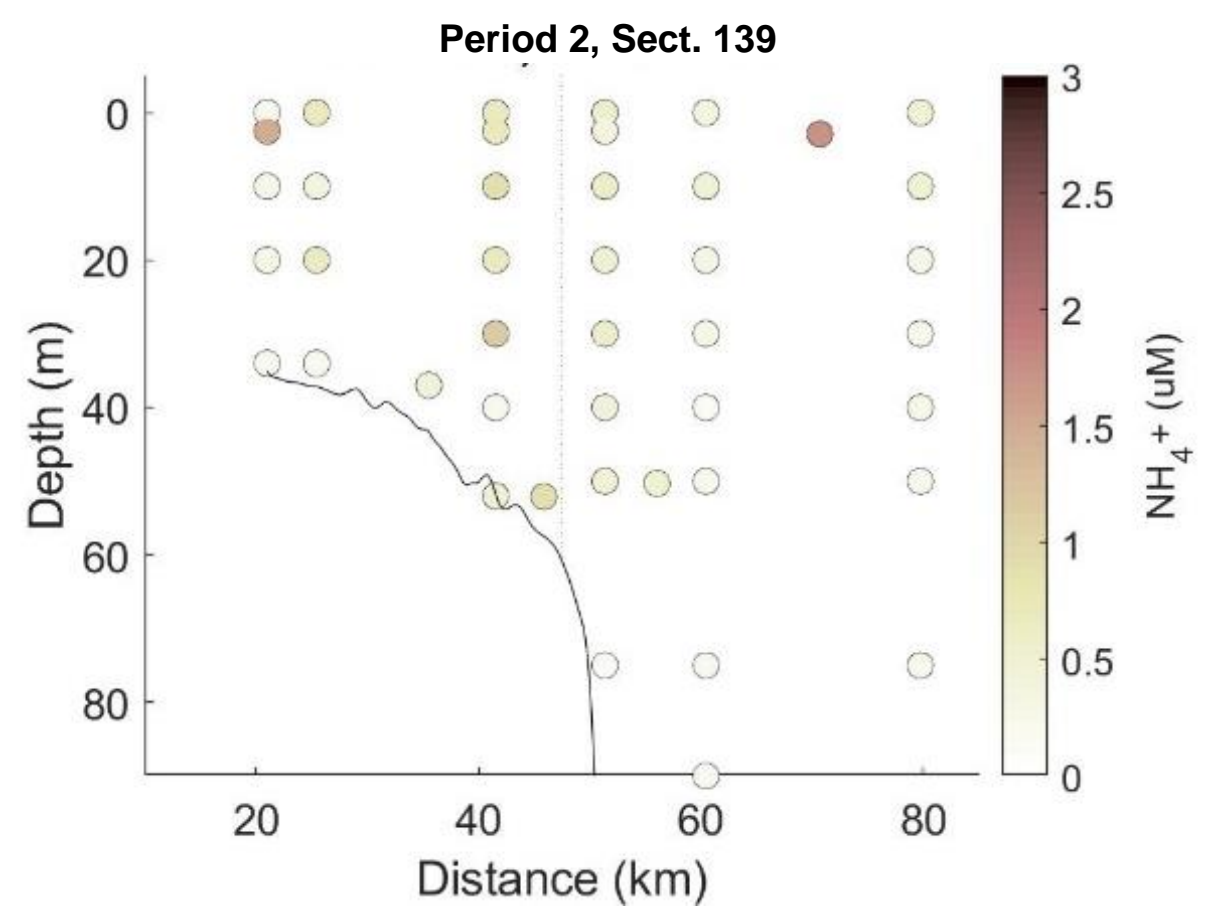

Period 2, Sect. 144

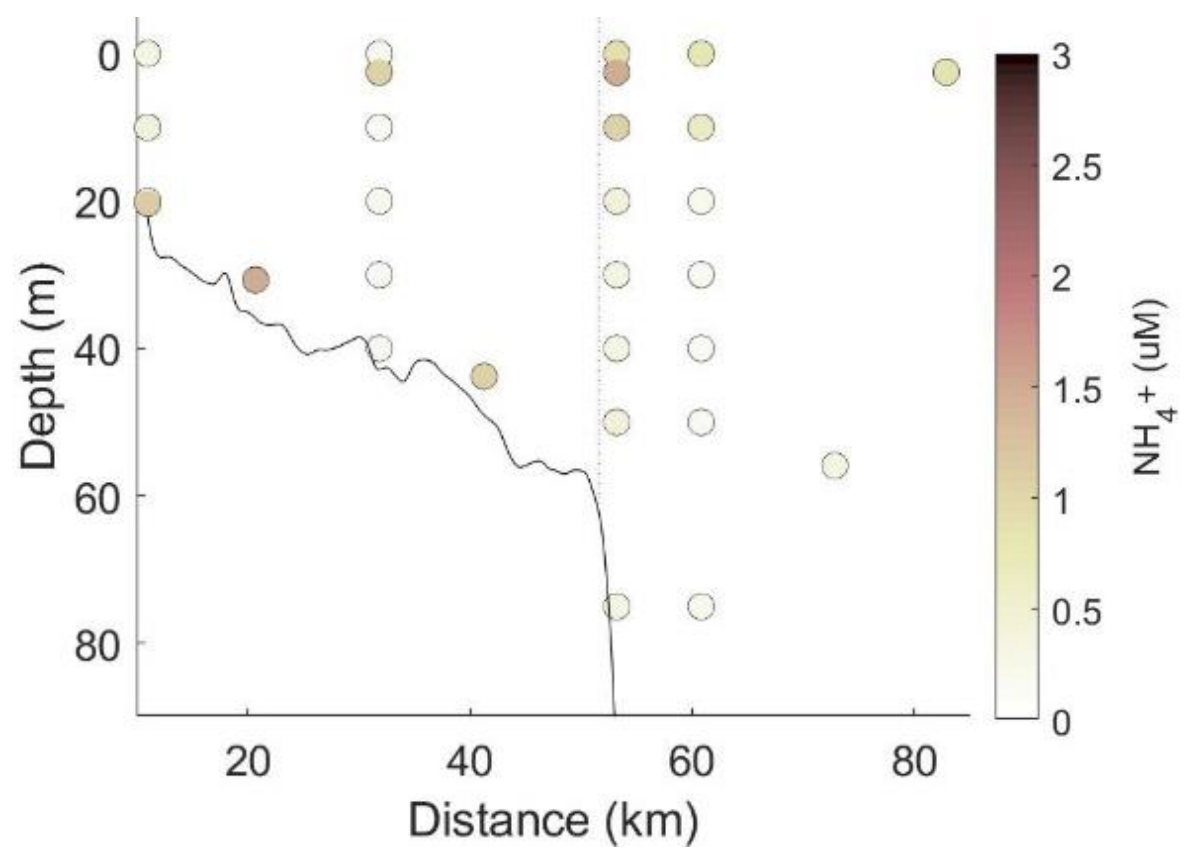

Figure S5 Ammonium concentrations in the eastern Beaufort Sea during period 2 (Nov 4-8). The black line shows the bathymetry. The gray dashed line marks the approximate shelf edge. 


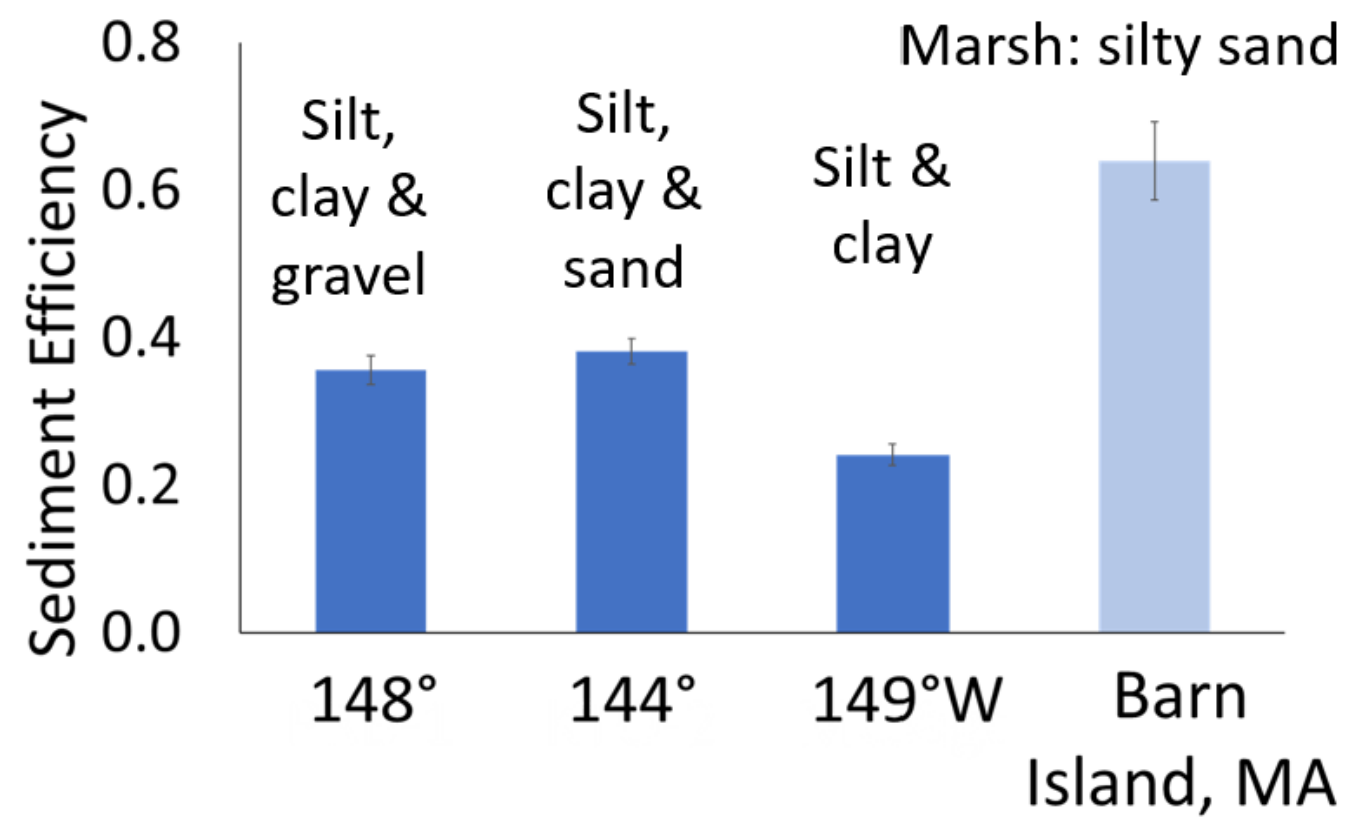

Figure S6 Sediment efficiencies for the 220-channel of the Radium Delayed Coincidence Counter using Th-232-spiked sediment. The method was following Cai et al. (2012). The light blue bar is the sediment efficiency for marsh sands from Barn Island, MA (Shi et al. 2018). 
Chapter 4: Summary and future research directions 
Radon-222 and radium isotopes are valuable tools for studying sediment-water interactions (SWIs) and how these processes impact the biogeochemical cycling of carbon and nutrients in Arctic environments. In this thesis I have applied radon-222 $\left(\mathrm{t}_{1 / 2}=3.82 \mathrm{~d}\right)$ and the quartet of radium isotopes $\left({ }^{223} \mathrm{Ra}, \mathrm{t}_{1 / 2}=11.4 \mathrm{~d} ;{ }^{224} \mathrm{Ra}, \mathrm{t}_{1 / 2}=3.66 \mathrm{~d} ;{ }^{226} \mathrm{Ra}, \mathrm{t}_{1 / 2}=1600 \mathrm{y} ;{ }^{228} \mathrm{Ra}, \mathrm{t}_{1 / 2}\right.$ $=5.75 \mathrm{y})$ as tracers in strongly contrasting Arctic environments, from shallow subarctic lakes to and the continental shelf. The fieldwork campaigns to the remote regions of Alaska in summer and the Beaufort shelf during autumn freeze-up allowed me to collect unique datasets that inform some the first measurements of groundwater discharge in tundra lakes and of winter water formation during autumn freeze-up.

In Chapter 2, I applied ${ }^{222} \mathrm{Rn}$ as a tracer of groundwater discharge and methane sources in a shallow, tundra lake in the in subarctic Alaska (Dabrowski et al., 2019); although ${ }^{222} \mathrm{Rn}$ was used once before to quantify groundwater discharge into an Arctic lake (Paytan et al., 2015), the type of lake in this study is much more common across the Arctic, and therefore has greater implications for groundwater sources and carbon budgets in the Arctic freshwater system. First, I used a mass balance approach to quantify all sources and sinks of ${ }^{222} \mathrm{Rn}$ into the lake other than groundwater, and then solved for the groundwater discharge flux by difference. Average groundwater fluxes in summer of 2017 were $1.2 \pm 0.6$ and $4.3 \pm 2.0 \mathrm{~cm} \mathrm{~d}^{-1}$, respectively as conservative and upper limit estimates. I then combined groundwater measurements of ${ }^{222} \mathrm{Rn}$ with $\mathrm{CH}_{4}$ to quantify groundwater-derived $\mathrm{CH}_{4}$ fluxes of $7-24 \mathrm{mmol} \mathrm{m}^{-2} \mathrm{~d}^{-1}$. These significantly exceeded diffusive air-water $\mathrm{CH}_{4}$ fluxes $\left(1.3-2.3 \mathrm{mmol} \mathrm{m}^{-2} \mathrm{~d}^{-1}\right)$ from the lake to the atmosphere, suggesting that groundwater is an important source of $\mathrm{CH}_{4}$ to Arctic lakes and may drive observed $\mathrm{CH}_{4}$ emissions. These findings indicate that deltaic lakes across warmer permafrost regions may act as important hotspots for $\mathrm{CH}_{4}$ release across Arctic landscapes.

An important next step is to investigate the role of and quantify groundwater discharge in Arctic lakes in seasons other than summer. In late summer and autumn, when the active layer is deepest, groundwater flow should be the largest relative to surface water flow (Bring et al., 2016), increasing the transport of sediment-derived materials such as regenerated nutrients, methane, and dissolved organic carbon. As active layers deepen and the thaw season increases in length and the hydrological cycle intensifies, groundwater flow will increase in the Arctic (Bring et al., 2016; Walvoord \& Kurylyk, 2016). There have also been few studies on groundwater processes and biogeochemical impacts during freeze-up when different mechanisms such as squeezing of the active layer by freezing and thermohaline circulation in bottom sediments are driving sediment-water interaction. Observations in these seasons would improve our understanding of the role of groundwater discharge and inform climate and biogeochemical models of future changes in the Arctic.

In Chapter 3, I applied the quartet of radium isotopes as tracers of sediment-water interaction on the Beaufort shelf in the Arctic Ocean. I specifically investigated autumn storms and winter water formation as drivers of sediment-water interaction. The timeseries in this study included repeated occupations of the central Beaufort shelf, and is among the first to document 
the physical and chemical impacts of winter water formation in the Beaufort Sea. Hydrographic data are combined with meteorological and sea ice concentration data and compared to measurements of the radium isotope quartet and ammonium, an important nutrient source for primary productivity (Cota et al., 1996; Tremblay et al., 2006). In addition to year-round mooring observations (Itoh et al., 2012; Weingartner et al., 1998), late spring cruises (Pacini et al., 2019; Vieira et al., 2019), and modeling evidence (Kipp et al., 2020), this study highlights the patchiness of the ice formation process and its ability to drive dissolved constituents from sediment porewaters into the water column throughout the autumn, winter, and early spring. It further suggests that these events are episodic in nature, and that mesoscale water column features can drive sediment-water exchange. Large inputs of ammonium were observed, which presumably occur throughout the winter and spring as leads in the ice allow for more ice formation. Since 2008, continued increases in primary production were driven by increases in biomass rather than open water area, likely due to an influx of new nutrients (Lewis et al., 2020). As the climate continues to warm, SWI during winter water formation in autumn through spring, will become a crucial source of nutrients that continues to support increases in productivity in the Arctic.

The next step for research on SWI in the Arctic Ocean should be to continue measurements of SWI throughout the year to determine drivers other than winter water formation, such as wind and potentially submarine groundwater discharge, which has not been well characterized in the Arctic (Lecher, 2017), which I predict will become increasingly important with sea ice and permafrost loss. High temporal resolution of radium isotope measurements and nutrients via year-round moorings could further elucidate the drivers of SWI throughout the year and help quantify nutrient inputs that are driving increases in primary productivity (Lewis et al., 2020). Increases in total shelf inputs to the central Arctic have been observed for ${ }^{228} \mathrm{Ra}$ and other trace elements and isotopes with sediment sources (Charette et al., 2020; Kipp et al., 2018; Rutgers van der Loeff et al., 2018), but disentangling the changes in river inputs and specific shelf processes can allow us to predict future changes in biogeochemical cycles in the Arctic as it continues to warm at an alarming rate. Measurements are especially needed on the under-sampled East Siberian shelf, which is large in area and a direct source for the largest surface current in the Arctic (Charette et al., 2020). The timeseries of radium isotope measurements in the Arctic should be expanded in spatial coverage and continued in order to track the changes on shelves and inputs of nutrients, carbon, and trace elements to the Arctic Ocean.

In summary, this thesis has shown how ${ }^{222} \mathrm{Rn}$ and radium isotopes can be applied to study sediment-water interactions in diverse Arctic environments and has improved our understanding of these processes both physically and as chemical sources of carbon and nutrients that impact biogeochemical cycles. Future research should continue to focus on studying sediment-water interaction throughout the year, especially in autumn through spring when there relatively few measurements in the Arctic, and in future years in order to understand the specific drivers 
contributing to changing carbon and nutrient fluxes as the climate warms. This thesis is an important contribution to our understanding of the sources of carbon and nutrients in Arctic environments, but these sources will shift and may become more important due to rapid climate change. 


\section{References}

Bring, A., Fedorova, I., Dibike, Y., Hinzman, L., Mård, J., Mernild, S. H., et al. (2016). Arctic terrestrial hydrology: A synthesis of processes, regional effects, and research challenges. Journal of Geophysical Research: Biogeosciences, 121(3), 621-649.

https://doi.org/10.1002/2015JG003131

Charette, M. A., Kipp, L. E., Jensen, L. T., Dabrowski, J. S., Whitmore, L. M., Fitzsimmons, J. N., et al. (2020). The Transpolar Drift as a Source of Riverine and Shelf-Derived Trace Elements to the Central Arctic Ocean. Journal of Geophysical Research: Oceans, (125), e2019JC015920. https://doi.org/10.1029/2019jc015920

Cota, G. F., Pomeroy, L. R., Harrison, W. G., Jones, E. P., Peters, F., Sheldon, W. M., \& Weingartner, T. R. (1996). Nutrients, primary production and microbial heterotrophy in the southeastern Chukchi Sea: Arctic summer nutrient depletion and heterotrophy. Marine Ecology Progress Series, 135(1-3), 247-258. https://doi.org/10.3354/meps135247

Dabrowski, J. S., Charette, M. A., Mann, P. J., Ludwig, S. M., Natali, S. M., Holmes, R. M., et al. (2019). Using radon to quantify groundwater discharge and methane fluxes to a shallow, tundra lake on the Yukon-Kuskokwim Delta, Alaska. Biogeochemistry, submitted.

Itoh, M., Shimada, K., Kamoshida, T., McLaughlin, F., Carmack, E., \& Nishino, S. (2012). Interannual variability of Pacific Winter Water inflow through Barrow Canyon from 2000 to 2006. Journal of Oceanography, 68(4), 575-592. https://doi.org/10.1007/s10872-012-0120-1

Kipp, L. E., Charette, M. A., Moore, W. S., Henderson, P. B., \& Rigor, I. G. (2018). Increased fluxes of shelf-derived materials to the central Arctic Ocean. Science Advances, 4(1), 1-10. https://doi.org/10.1126/sciadv.aao1302

Kipp, L. E., Spall, M. A., Pickart, R. S., Kadko, D. C., Moore, W. S., Dabrowski, J. S., \& Charette, M. A. (2020). Observational and Modeling Evidence of Seasonal Trends in SedimentDerived Material Inputs to the Chukchi Sea. Journal of Geophysical Research: Oceans, 125(5), 1-13. https://doi.org/10.1029/2019jc016007

Lecher, A. L. (2017). Groundwater Discharge in the Arctic: A Review of Studies and Implications for Biogeochemistry. Hydrology, 4(3), 41. https://doi.org/10.3390/hydrology4030041

Lewis, K. M., van Dijken, G. L., \& Arrigo, K. R. (2020). Changes in phytoplankton concentration now drive increased Arctic Ocean primary production. Science (New York, N.Y.), 369(6500), 198-202. https://doi.org/10.1126/science.aay8380

Pacini, A., Moore, G. W. K., Pickart, R. S., Nobre, C., Bahr, F., Våge, K., \& Arrigo, K. R. (2019). Characteristics and Transformation of Pacific Winter Water on the Chukchi Sea Shelf in Late Spring. Journal of Geophysical Research: Oceans, 124(10), 7153-7177. https://doi.org/10.1029/2019JC015261 
Paytan, A., Lecher, A. L., Dimova, N., Sparrow, K. J., Kodovska, F. G.-T., Murray, J., et al. (2015). Methane transport from the active layer to lakes in the Arctic using Toolik Lake, Alaska, as a case study. Proceedings of the National Academy of Sciences, 112(12), 3636-3640. https://doi.org/10.1073/pnas.1417392112

Rutgers van der Loeff, M. M., Kipp, L., Charette, M. A., Moore, W. S., Black, E., Stimac, I., et al. (2018). Radium Isotopes Across the Arctic Ocean Show Time Scales of Water Mass Ventilation and Increasing Shelf Inputs. Journal of Geophysical Research: Oceans, 123(7), 4853-4873. https://doi.org/10.1029/2018JC013888

Tremblay, J. É., Michel, C., Hobson, K. A., Gosselin, M., \& Price, N. M. (2006). Bloom dynamics in early opening waters of the Arctic Ocean. Limnology and Oceanography, 51(2), 900-912. https://doi.org/10.4319/lo.2006.51.2.0900

Vieira, L. H., Achterberg, E. P., Scholten, J., Beck, A. J., Liebetrau, V., Mills, M. M., \& Arrigo, K. R. (2019). Benthic fluxes of trace metals in the Chukchi Sea and their transport into the Arctic Ocean. Marine Chemistry, 208, 43-55. https://doi.org/10.1016/j.marchem.2018.11.001

Walvoord, M. A., \& Kurylyk, B. L. (2016). Hydrologic Impacts of Thawing Permafrost-A Review. Vadose Zone Journal, 15(6), 1-20. https://doi.org/10.2136/vzj2016.01.0010

Weingartner, T. J., Cavalieri, D. J., Aagaard, K., \& Sasaki, Y. (1998). Circulation, dense water formation, and outflow on the northeast Chukchi shelf. Journal of Geophysical Research C: Oceans, 103(3334), 7647-7661. https://doi.org/10.1029/98jc00374 